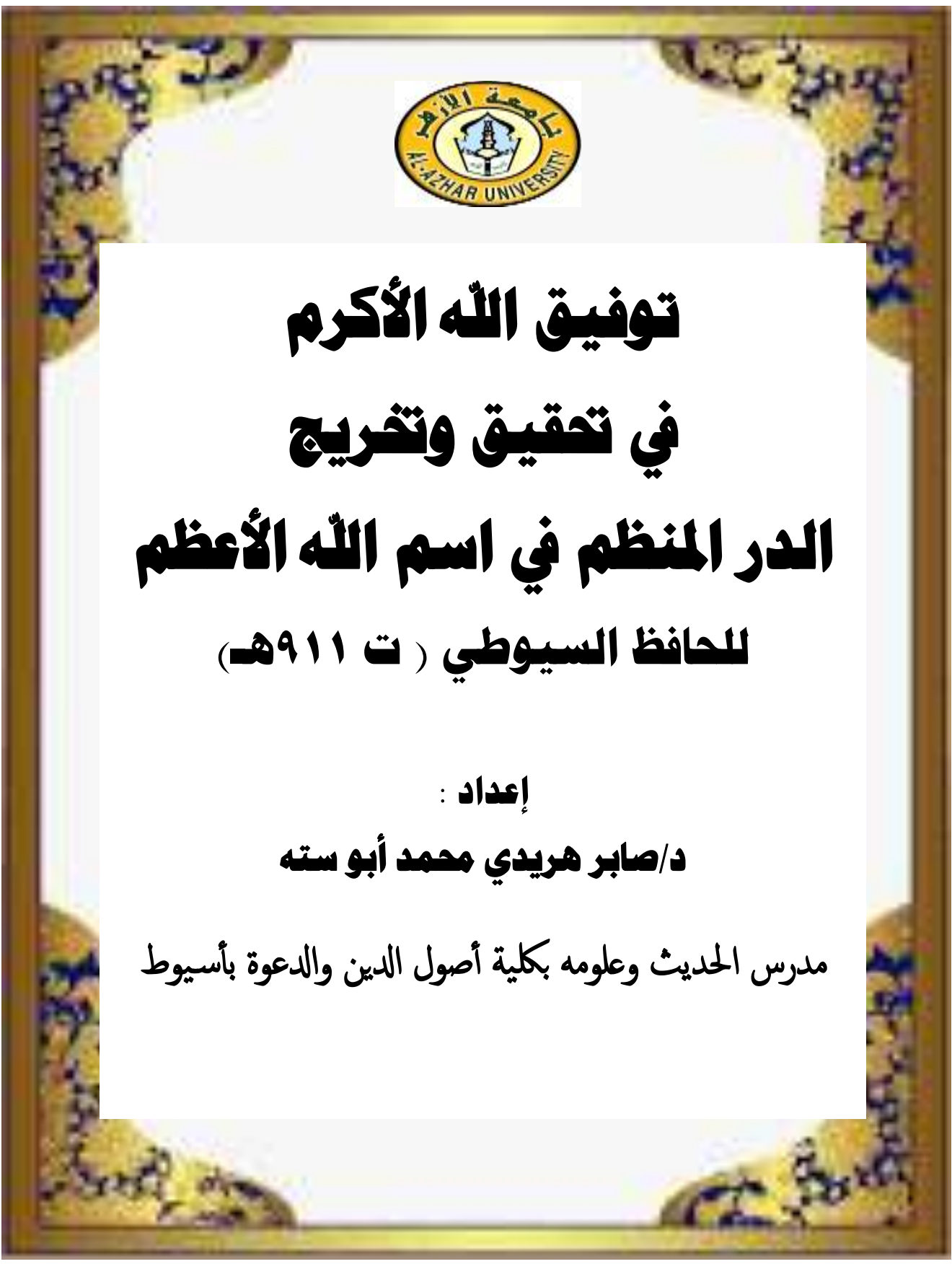

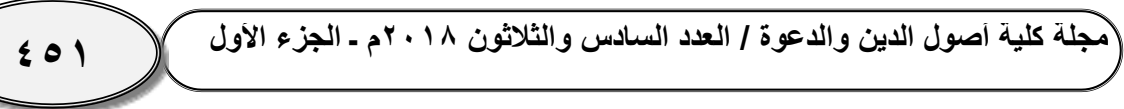




\section{مط:مى البمث}

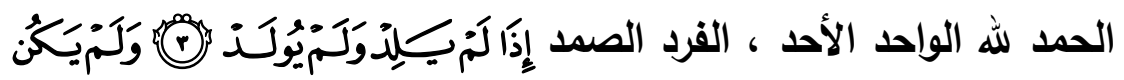

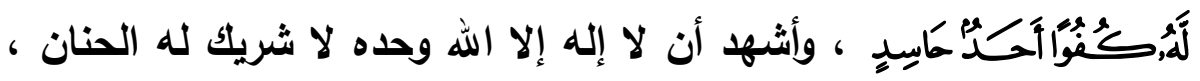

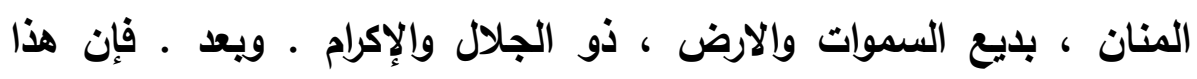
المخطوط يعالج قضية في غاية الأهمية، ألا وهي : التعرف على اسم الله الأعظم الذي إذا دعي به أجاب ، وإذا سئل به أعطى، وكفي بتحصيل هذه اله

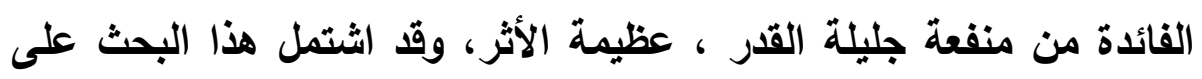

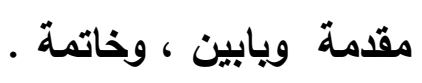

أما الاقدمهة فتثتثل علي خطة البحث ، وأهمية الاراسة . والباب الأول : التعريف بالمخطوط ومؤلفه ، ويشتمل علي فصلين : الفصل الأول : التعريف بالإمام جلال الدين السيوطي ، ويشتمل علي ثلاثة مباحث : - مبث

• المبحث الأول : اسمه ، ونسبه ، وكنيته ، ولقبه، ومولده .

- المبحث الثاني : نثأته وطلبه للعلم ، وثثاء العلماء عليه . • المبحث الثالث : مصنفاته ، ووفاته . الفصل الثاني : التعريف بالمخطوط " الار المنظم في اسم الله الأعظم " ويشتمل علي ثلاثة مباحث :

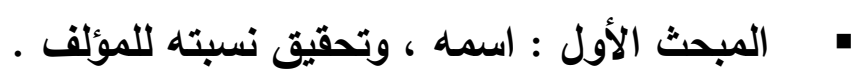


• المبحث الثاني : سبب تأليفه، ومنهج الإمام فيه، والمصادر التي

اعتمد عليها. ويشتمل علي مطلبين :

• الأول : سبب تأليفه ، ومنهجه فيه .

• الثاني : المصادر التي اعتمد عليها .

• المبحث الثالث : وصف النسخ .

الباب الثاني : النص المحقق •

وأما الغاتمة : فقد اشتملت علي أهم النتائج ، ومنها :

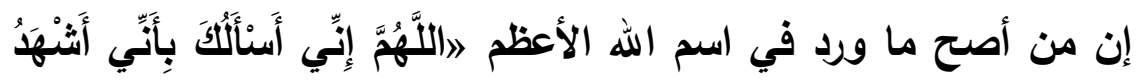

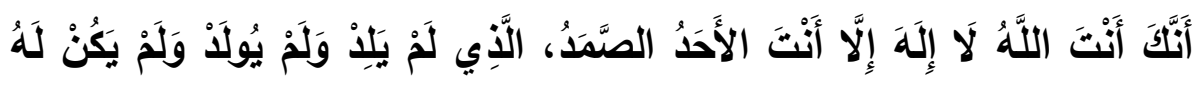

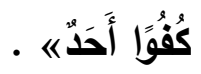

وصلي الله علي سيدنا محمد وعلى آله وصحبه وسلم 


\section{Summary of the Research}

Praise to Allah the one, Allah-us-Samad: The Self-Sustainer Master," He begets not, nor was He begotten, and there is none co-equal or comparable unto him". And I'm testifying that there is no god but Allah, and Muhammad is the Apostle of Allah.

\section{After that,}

This manuscript encountered an extremely important issue, namely, the recognition of the greatest name of Allah" Glory be to him" and the sayings of the scholars, and it's sufficient to take advantages of achieving this great merit.

This manuscript has been collected twenty sayings in the statement the greatest name of Allah, among these sayings what is correct, and what isn't correct, or through a sleeping vision of some righteous men. And among the most correct sayings came in this issue, the saying of the prophet Muhammad "Peace be upon him" to whom who was calling to Allah and said," The Messenger of Allah " Peace be Upon him" heard a man saying: O Allah, I ask Thee, I bear witness that there is no god but Thou, the One, He to Whom men repair, Who has not begotten, and has not been begotten, and to Whom no one is equal, and he said: You have supplicated Allah using His Greatest Name, when asked with this name He gives, and when supplicated by this name he answers".

This Study included two sections: the First one of them dealt with the definition of Imam Al-Suyuti, the author of the manuscript in terms of: his name, descent, birth, origin, the praise of the scholars, his works, and his death in a separate chapter.

Followed by the definition of the Manuscript itself in terms of : examination its name, its relation to the author, the reason for its authorship, the sources relied on them, and a description to the copies that were adopted in a second chapter.

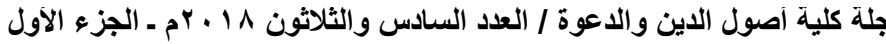


Whereas the second section included an examination and documentation and the study of the text of the manuscript, finally, the research was ending by mentioning the most important results.

Blessings and Peace be upon the prophet Muhammad, his family and companions

\section{The researcher}

Dr.Saber Haredy Mohamed

The lecturer of Hadith and its sciences, Foundations of Religion Faculty, Azhar University, Assiut Branch 


\section{هقدمة}

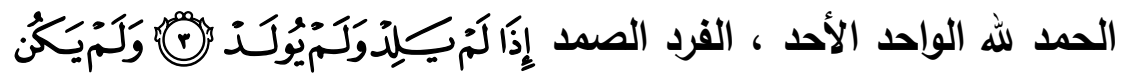

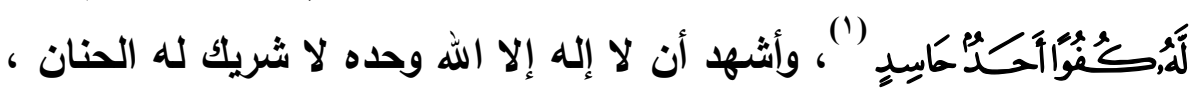

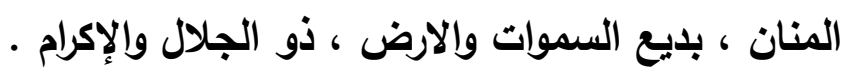

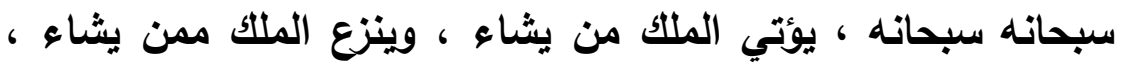
ويعز من يشاء ، ويذل من يشاء ، بيده الخير ، وهو علي كل شيء قدير .

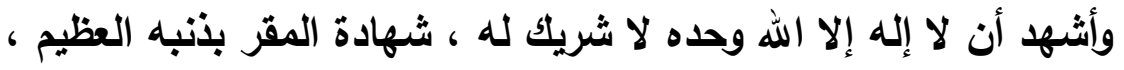

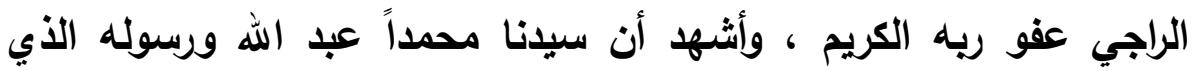

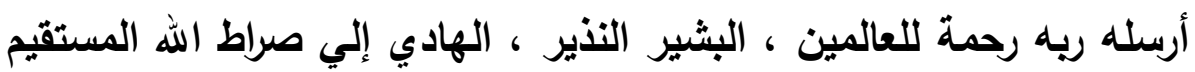
، وعلى آله وصحبه وسلم أجمعين ، ومن تبعهم بإحسان إلى يوم الدين.

\section{ـأما بعد -}

فإن من أجل ما طُبِ به النعم ، واستُدفع به النقم ، وغُفِر به كبائر الإثم

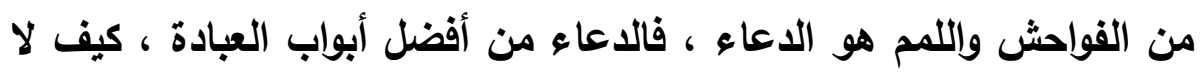

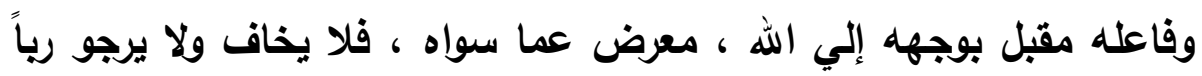
سواه ، بل وصفه النبي

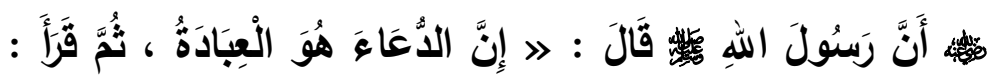

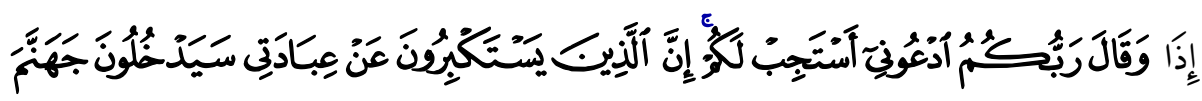




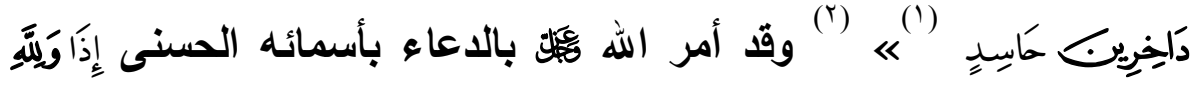
(r)

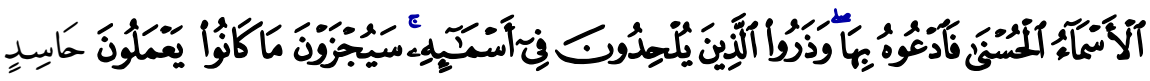
ومن مظنة إجابة الاعاء ، الاعاء بالاسم الأعظم ، وقد جمع الإمام السيوطي أقوال العلماء في بيان هذا الاسم في رسالة سماها " الده المنظم ــاســــاله الكاعظم " جمع فيها من الارر ، والفوائد ، والفرائد ما يبهر جمالها العين ، ويثلج الصدر ، في عقد فريد وتسلسل بليع ، فلما وقعت عيني عليها جذبت نحوها ، خاصة وأن هذا الموضوع ليدور في خلاي منذ سنوات عدة ، فعقدت

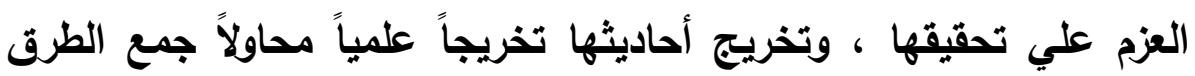

(ץ) الحديث أخرجه من طريق أبي معاوية : الإمام الترمذي في السنن ك : التفسير ، ب :

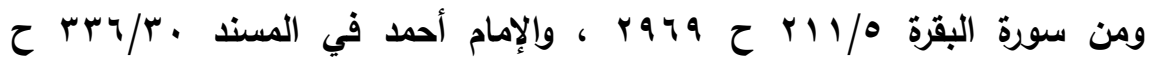

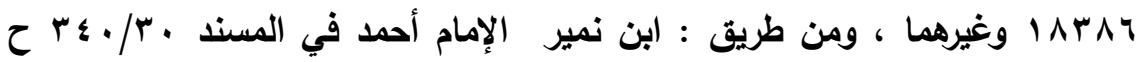

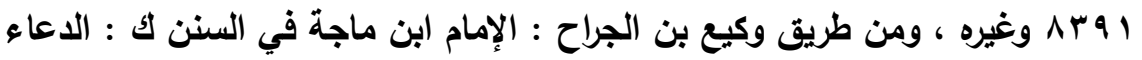

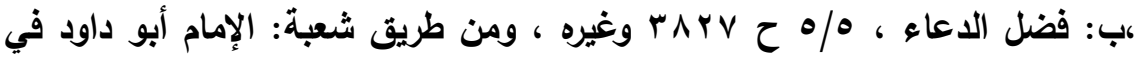

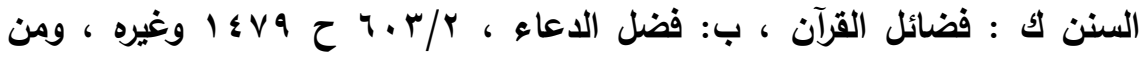

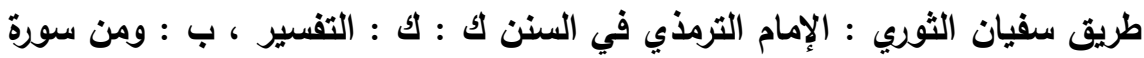

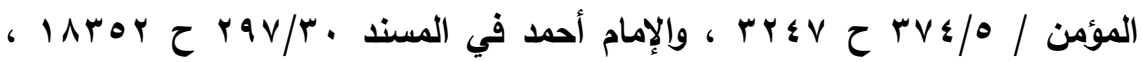

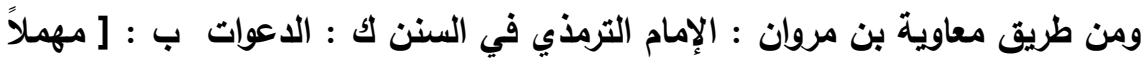
] وغيره ( جميعه ) عن سليمان الأعمش عن ذر بن عبد الله الهمداني عن يسيع

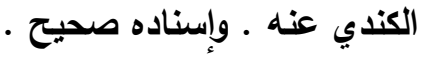

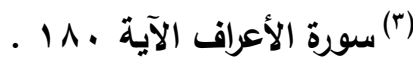


والمتابعات لكل ما فيها من أحاديث وآثار قرر الجها والطاقة ، راجياً من العلي القدير ، أن يوفقتي لما فيه رضاه ، وأن يجعل هذا العمل خالصاً لوجهه الكريم ، إنه ولي ذلك ومولاه .

\section{خطة البمث :}

وقد اقتضت طبيعة البحث أن يشتمل على مقدمة ، ويابين ، وخاتمة : أما المقدمة فتثتمل علي خطة البحث ، وأهمية الاراسة . والباب الأول : التعريف بالمخطوط ومؤلفه ، ويشتمل علي فصلين: الفصل الأول : التعريف بالإمام جلال الدين السيوطي ، ويشتمل علي ثلاثة مباحث :

ه المبحث الأول : اسمه ، ونسبه ، وكنيته ، ولقبه، ومولده .

" المبحث الثاني : نشأته وطلبه للعلم ، وثناء العلماء عليه . • المبحث الثالث : مصنفاته ، ووفاته . .

الفصل الثاني : التعريف بالمخطوط " الار المنظم في اسم الله الأعظم " ويشتمل علي ثلاثة مباحث :

المبحث الأول : اسمه ، وتحقيق نسبته للمؤلف .

• المبحث الثاني : سبب تأليفه، ومنهج الإمام فيه، والمصادر

التي اعتمد عليها. ويشتمل علي مطلبين :

• الأول : سبب تأليفه ، ومنهجه فيه .

• الثاني : المصادر التي اعتمد عليها . 
• المبحث الثالث : وصف النستخ .

الباب الثاني : النص المحقق •

وأما الخاتمة : فقد اشتملت علي أهم النتائج ، ثم ذيلت البحث بفهرس

- المراجع

\section{أهميهية الدراسة :}

إن أهمية أي موضوع إنما هي مستمدة من موضوعه، وهذا المخطوط إنما يعالج قضية في غاية الأهمية، ألا وهي : التعرف على اسم الله الأعظم الذي إذا دعى به أجاب ، وإذا سئل به أعطى، وكفي بتحصيل هذه الفائدة من لهن منفعة جليلة القدر ، عظيمة الأثر، فقد كثر الكلام حول هذا الاسم المبارك ، وخاض فيه بعض الجهلة فأعرضوا عن الثابت عن المعصوم لهم شياطين الإنس والجن ، حتى أطلقوا اسم الله الأعظم على ألفاظ غير مفهومة م منامة

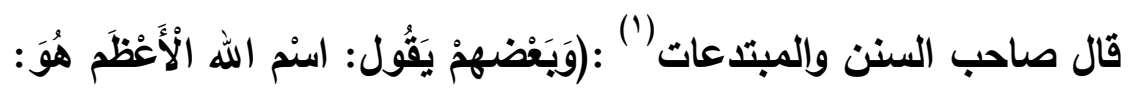
طهُور بدعث محبيه صوره سققاً طيس سقاطيم أحون قَاف أَدَم حمهاء آمين.

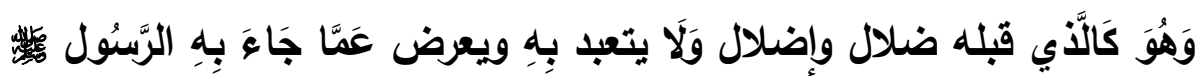

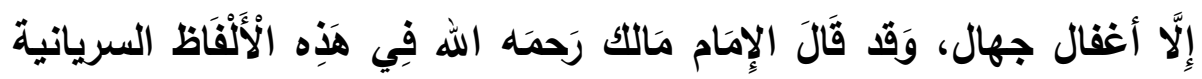
والعبرانية والعجمية: وَمَا يذْريك لَعَلَّهَا تكون كفرا ) أهـ وقد أجاد وأفاد الحافظ

(1) السنن والمبتدعات المتعلقة بالأذكار والصلوات لمحمد بن أحمد عبد السلام خضر

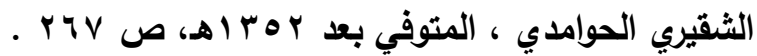


السيوطي في جمعه للأقوال ، وعرضها ، حتى وصلت إلي عثرين قولاً ذاكراً

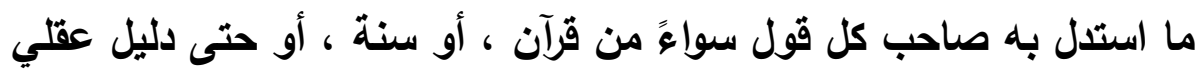

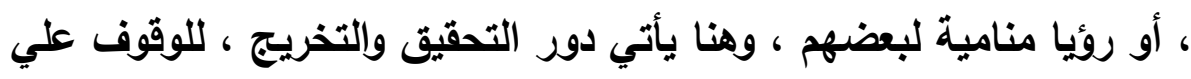

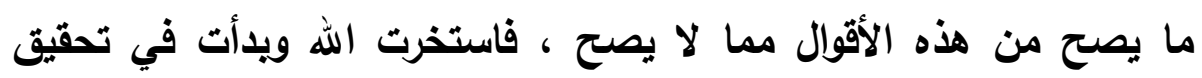

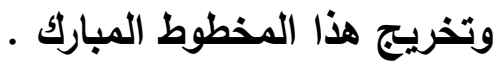




\section{الباب الأول : التعريف بالافطوط ومهؤلفه}

\section{الفمل الأول : التعريف بالإهام جلال الدين السيوطي}

\section{البمش الأول : اسمه ، ونسبه ، وكنيته ، ولقبه ، ومهولده .}

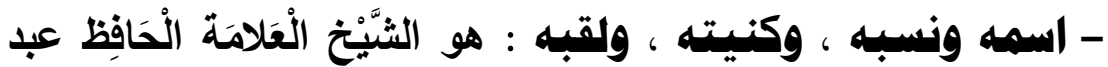

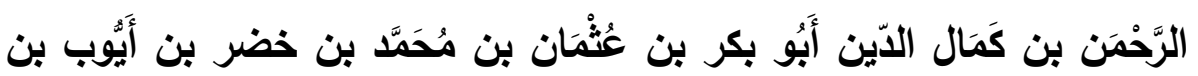

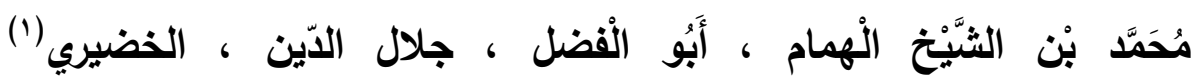

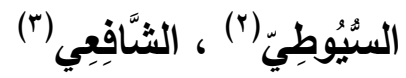

سَمَّاهُ وَالِاده بعد الْأُسْبُوع عبد الرَّحْمَنَ ، ولقبِه جلال الدَّين ، وكناه

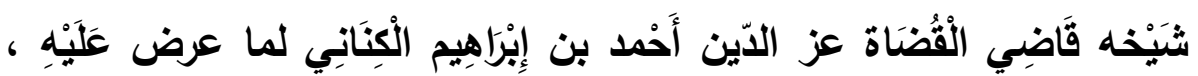

(') الخضيري : قال الحافظ السيوطي : (أما نسبتنا بالخضبري، فلا أعلم ما تكون إليه

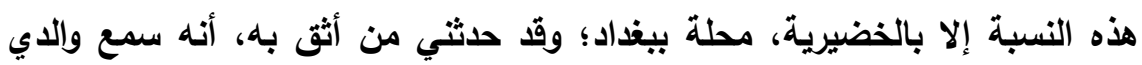

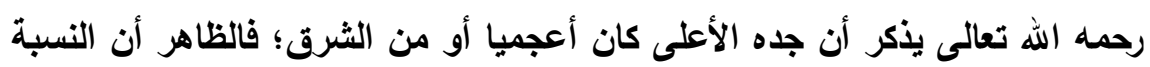

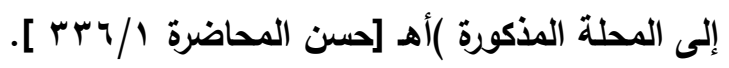

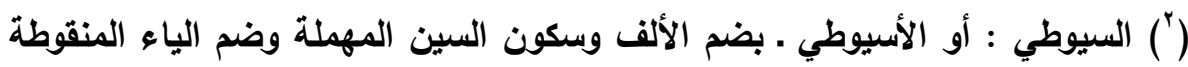

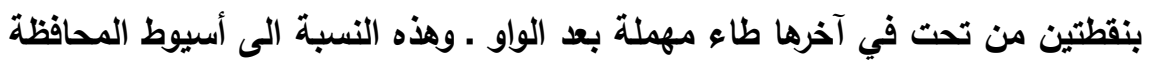

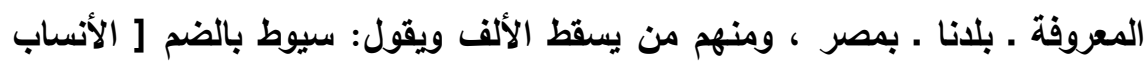

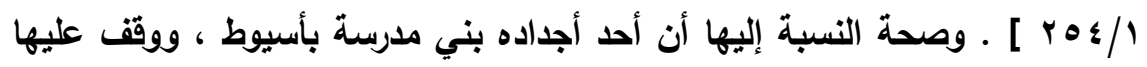

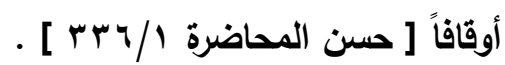

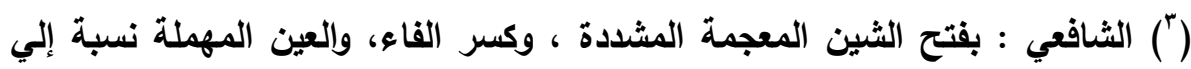
المذهب الشافعي لصاحبه الإمام محمد بن إدريس بن شافع المتوفى سنة أريع ومئتين

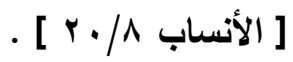




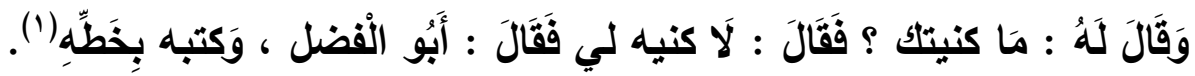

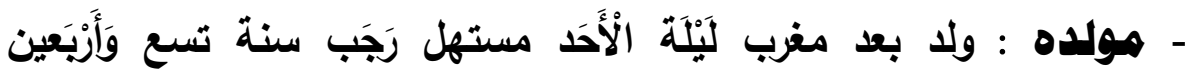

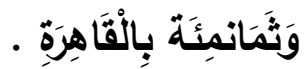

ومن طريف ما يذكر أنه ولا بين الكتب ، وكأنها علامة علي نبوغ هذا الطقل ، وعظيم شأنه في العلم ، ولذا كَانَ يلقب بِابْن الْكتب ، فكان أبوه من

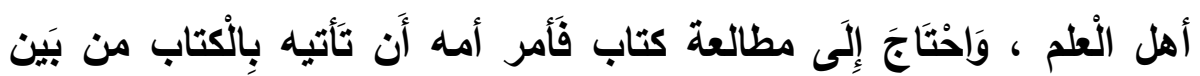

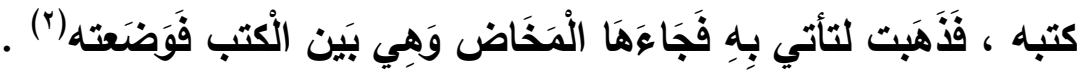

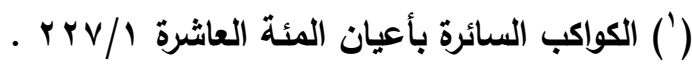

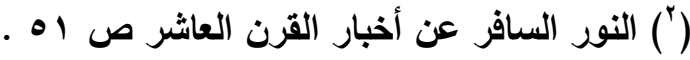




\section{المبحث الثاني : نشأته وطلبه للعلم ، وثناء العلهاء عليه}

ولد الإمام السيوطي في بيت محب للعلم وأهله ، فأحضره وَالِاده وعمره

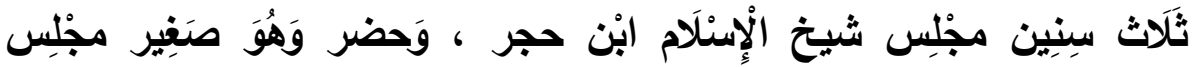

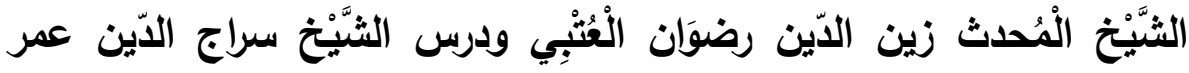

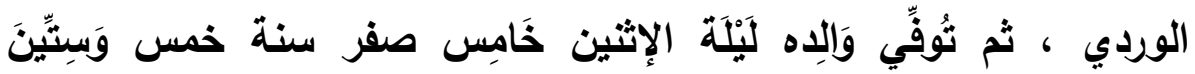

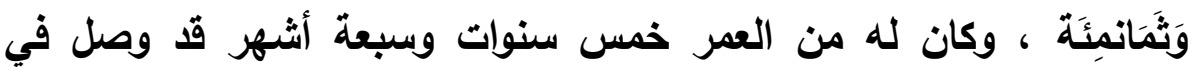
القراءة إذ ذاك إلى سورة التحريم، وأسند وصايته إلى جماعة منهم : العلامة

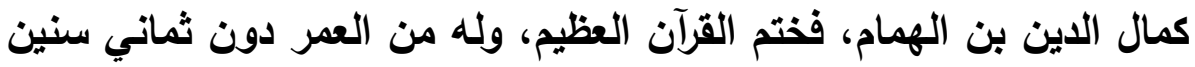

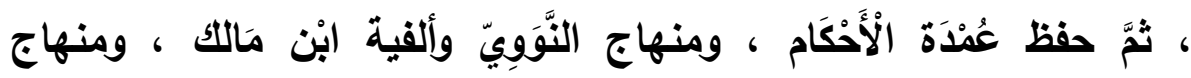

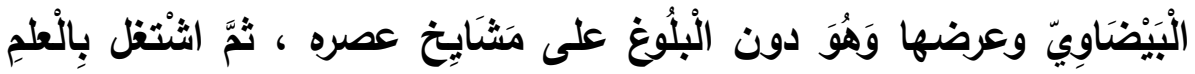

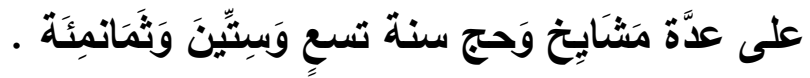

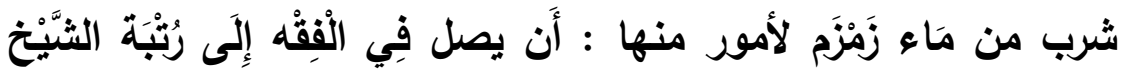

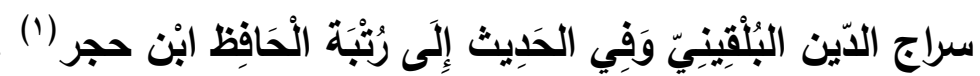
- ثناء العلهاء عليه : إن من يطالع سيرة الإمام السيوطي ، ومؤلفاته

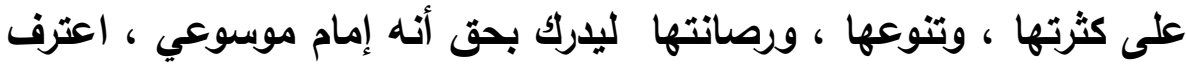

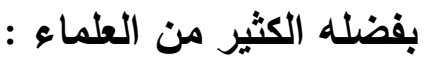

(') النور السافر عن أخبار القرن العاشر ص זه . 
قال الشيخ محي الاين العيدرس ت یرب.اهـ : الشيخ الْعَلامَة

(الْحَافِظ (') ( )

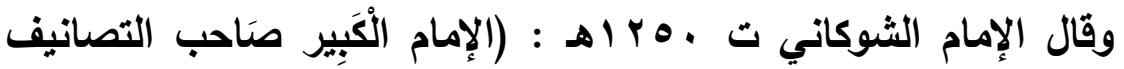

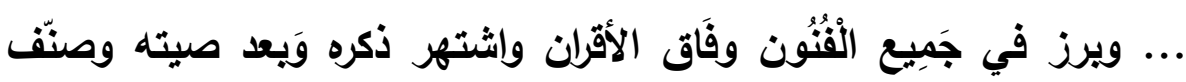

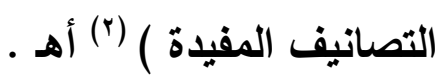

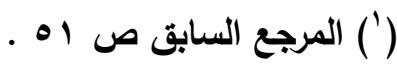

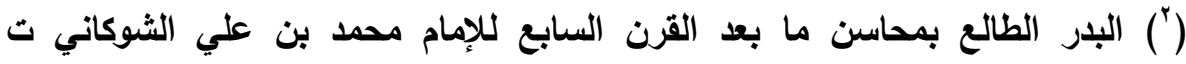

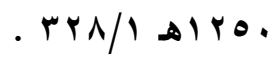




\section{المبحث الثالث : هؤلفاته ووفاته}

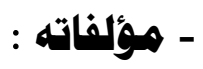

كان مما رذق الله به الإمام السيوطي كثرة مؤلفاته النافعة الماتعة ، فما من فن إلا وتجد له فيه مؤلف ، فقد نيفت عدتها على خمسمائة، وقا حباه

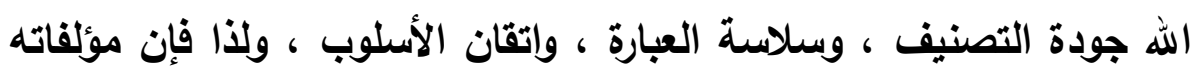

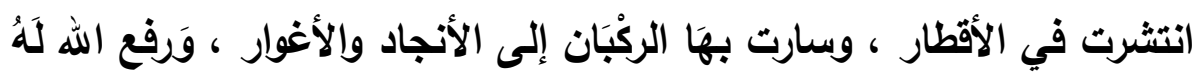

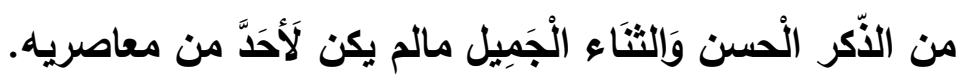
وكان في سرعة الكتابة وإلتأليف آية كبرى من آيات الله تعالى ، قال

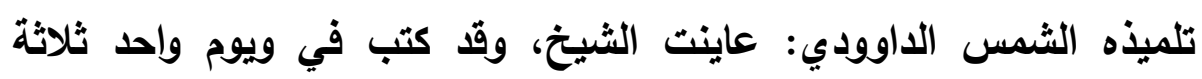

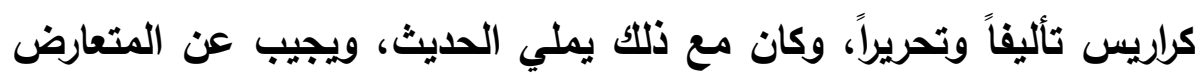

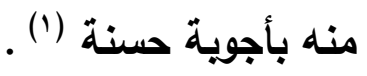

وَمن تصانيفه : الدّر المنتور فِي التَّفْبِير بالمأثَور ، وتناستق الدّرّ فِي

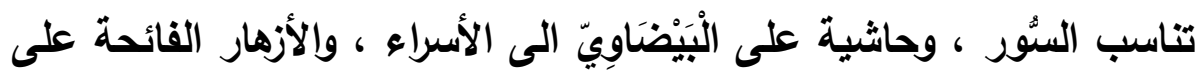

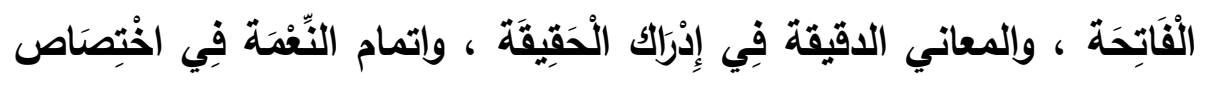

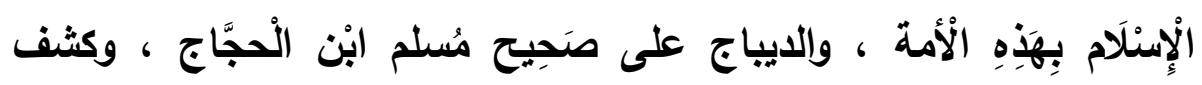

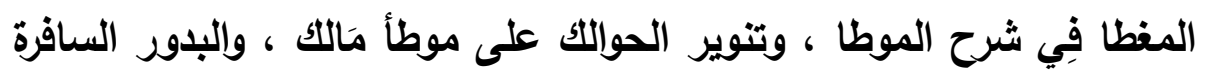

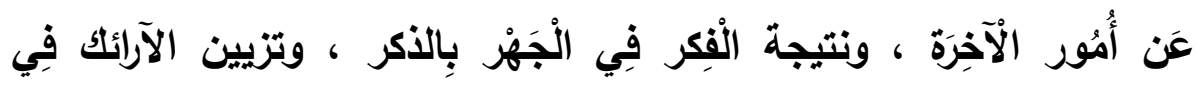

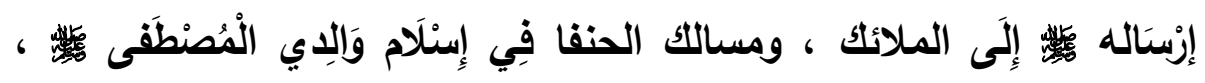


وَنشر العلمين المنيفين فِي إحْيَاء الْأَبَوَيْنِ الشريفين ، وذَم الْقَضَاء ، وذَم

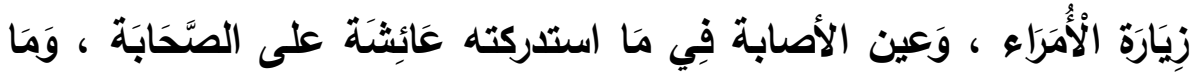

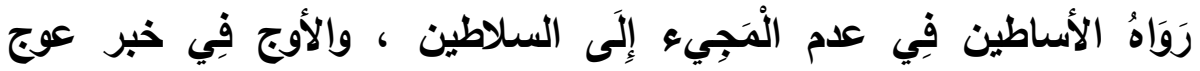
والوديك فِي الايك، وَثَرح الرَّوْض لِابْنِ الْمقري ، والبهجة المرضية فِي شرح الألفية والمسائل الوفية فِي نكت الحاجبتين ، والألفية على منوال التَّمرِير

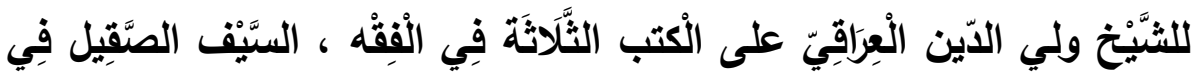

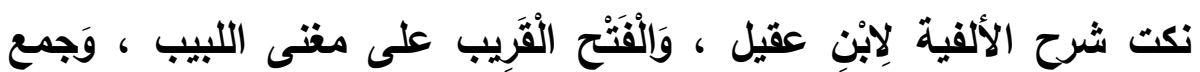
الْجَوَامِع فِي الْعَرَبَّةَّة ، وَثَرحه همع الهوامع ، والمرقاة الْعلية فِي شرح

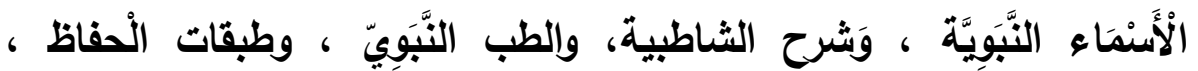

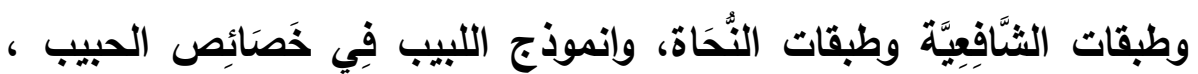

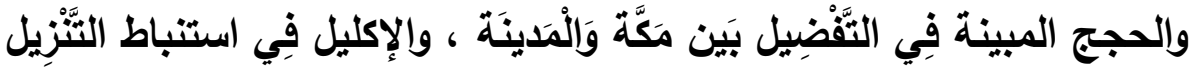

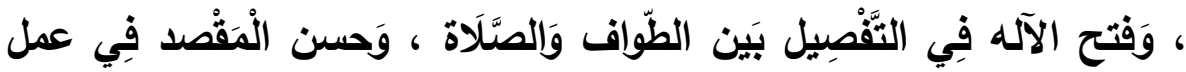
المولاد ، وتثثنيف الَُْركان فِي لَيْسَ فِي الامكان أبلدع مِمَّا كَانَ ، وفجر الاياجي فِي الأحاجي ، ونزهة الجلساء فِي أشعار النَّّاء ، وَثَرح الصُّدُور

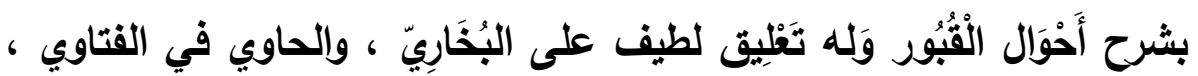
وله جزء الار المنظم في اسم الله الأعظم ـ موضوع الدراسة . ، وقد ذكره في الحاوي ، وَلهله غير ذَلِكَ الكثير .

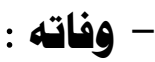

توفي · رحمه الله تعالى · فِي يَوْم الْجُمُعَة وَقتَ الْعَصْ تَّاسِع عشر جُمَادَى الأولى سنة إحْدَى عشرَة بعد التسنعمئَة من الهجرة ، في منزله بعد أن لن 
تمرض سبعة أيام بورم شديد في ذراعه الأيسر، وقد استكمل من العمر إحدى

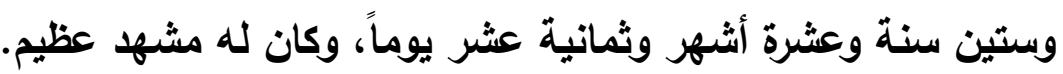
قيل: أخذ الغاسل قميصه وقبعه فاشترى بعض الناس قميصه من الغاسل بخمسة دنانير للتبرك به، وياع قبعه بثلاثة دنانير لذلك أيضاً، ورثاه عبد الباسط بن خليل الحنفي(') بقوله: مات جلال الدين غيث الورى ... مجتهر العصر إمام الوجود

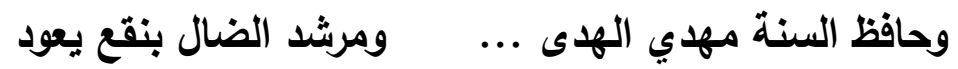
حتى قال :

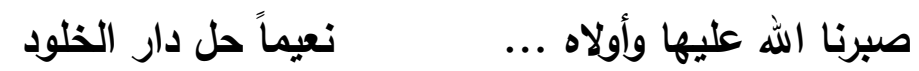

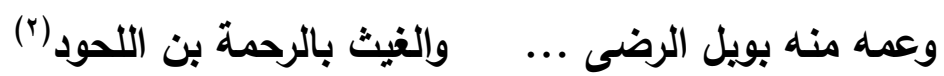
توالت عليه رحمات الله ما ليل عسعس ، وما صبح تنفس ، وجمعنا الله به مع النبيين والصديقين والثهراء والصالحين وحسن أولئك رفيقا ـ والحمد الله رب العالمين (َ)

(') عبد الباسط بن خليل بن شاهين الملطي، ثم القاهري، زين الدين: مؤرخ، له اشتغال

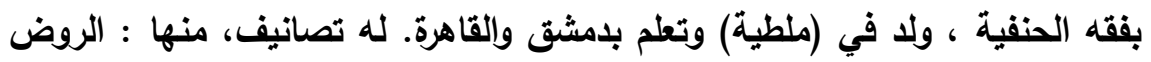

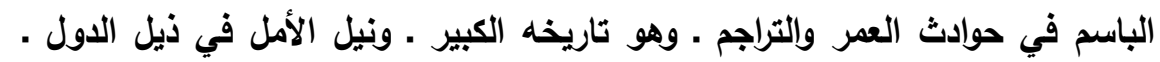

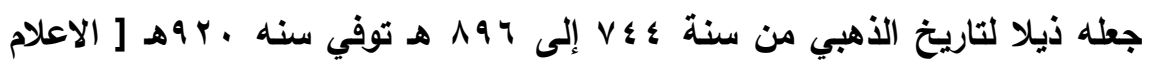

$$
\text { - [ r r } 4 / \%
$$

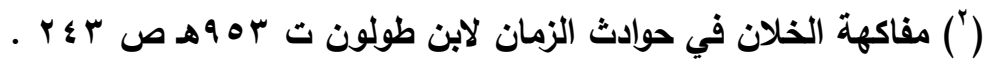

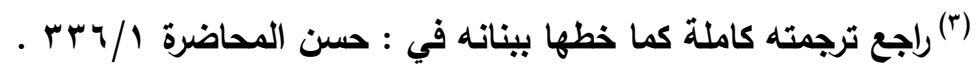


الفصل الثاني : التعريف بالمخطوط سـ هوضوع الدراسة المبمث الأول : ثمقيق اسم المفطوط ، ونسبته إلي مولهه

- تمقيق الاسم :

بالنظر إلي المخطوطات التي وققت عليها(1) نجد أن اسم هذه الرسالة 》 الار المنظم في اسم الله الأعظم 《 هكذا ورد العنوان في المخطوطة

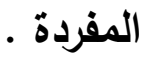

أما التي ضمن مخطوط كتاب الحاوي للفتاوي نجد أنه كتب في مقدمة

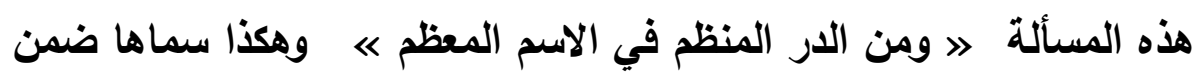

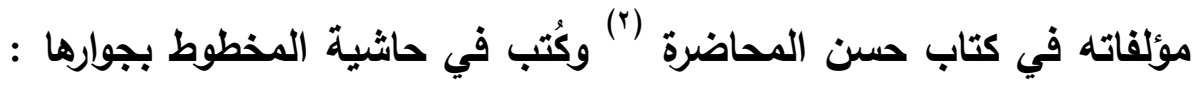

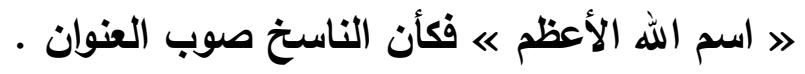

وقال صاحب كثف الظنون : 》 الار المنظم في الاسم الأعظم «") .

- نسبته إلي المؤلف :

لقد توافرت الأدلة علي صحة نسبة هذه المخطوطة للحافظ السيوطي بما لا يدع مجالاً للشكك ، منها :

(') وققت علي مخطوطتين الأولى مفردة ، والثانية ضمن مخطوط كتاب الحاوي للفتاوى

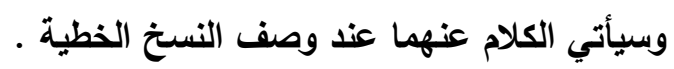

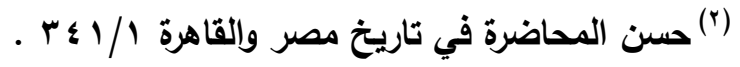

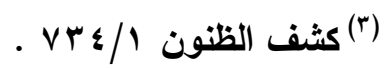

ะ १

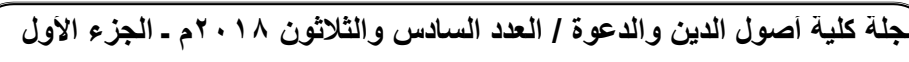


1-نسبها الحافظ السيوطي إلي نفسه في ترجمته فقال : ( وهذه أسماء مصنفاتي لتستفاد: ... فنكرها في فن الحديث باسم : الدر المنظم في

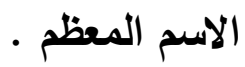
ץ - وجود النسخة المخطوطة ضمن مخطوط كتاب الحاوى للقتاوي ، وقد

طبع الكتاب ولله الحمد (') ب- ذكرها حاجي خليفة في كتاب كشف الظنون . كما سبق . ضمن مؤلفات الإمام السيوطي ، وقال: رسالة ، أولها: (الحمد لله، الذي له له له له الأسماء الحسنى ... الخ) ، تتبع فيها من الأحاديث والآثار ، ... وغيره

(') طبعته دار الفكر ، بيروت ـ لبنان ، سنة ؛ ب ؛ اهـ . ع . . rم . 
المبحث الثاني : سبب تأليفه، وهنهج الإهام فيه ، والاصادر

التي اعتمهد عليدها.

المطب الأول : سبب تأليفه وهنهج الإمام فيه :

- سبب تأليفه :

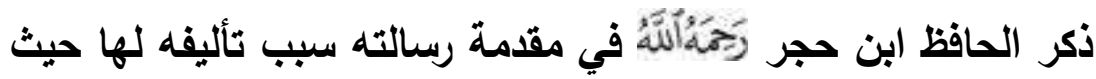

جاءت هذه الرسالة جواباً على أحد السائلين عن اسم الله الأعظم ، وما ورد

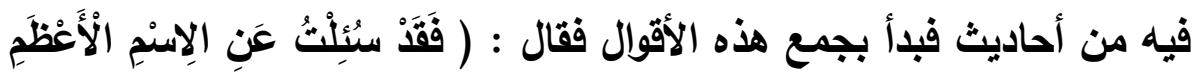

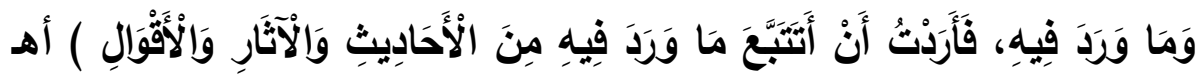

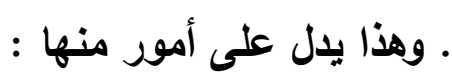

أ- إرادة الوصول إلى وجه الصواب في المسألة ، فكان قادراً على أن

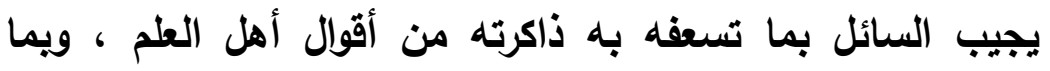

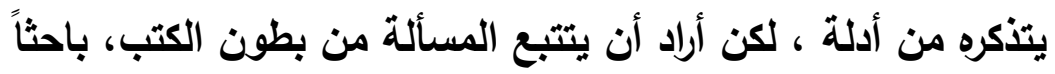

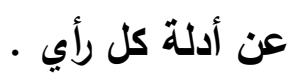

ب- حرصه علي عموم الاستفادة ، فكان من المكن أن يجيب السائل

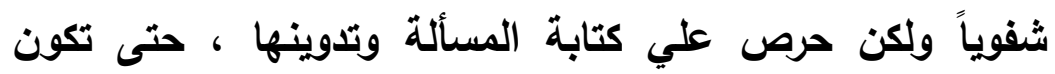

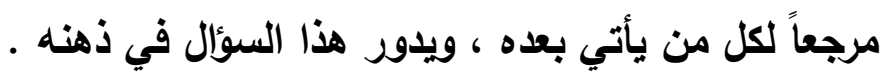

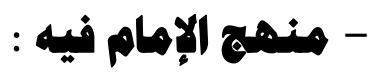
يمكن أن أجمل منهج الحافظ السيوطي في رسالته هذه في النقاط التالية : - 20 - n $\leqslant v$. جلم كلية اصول الدين والدعوة / العدد السادس والثلاثون ^ / ـ آم ـ الجزء الاول 
() تتبع الحافظ السيوطي أقوال العلماء في هذه المسألة فنكر عشرين

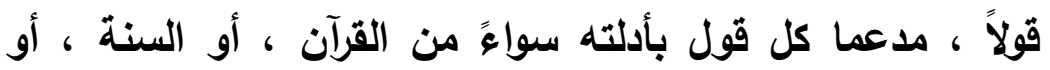

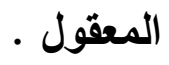

r) ينسب الأقوال إلى أصحابها ـ في الأعم الأغلب ـ فقال مثلاً في القول

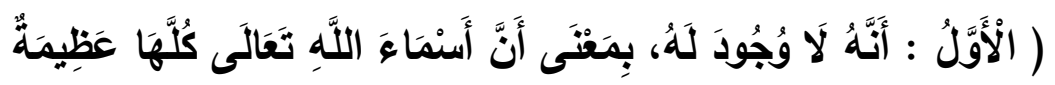

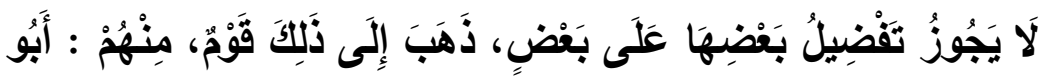

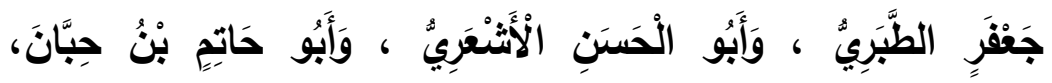

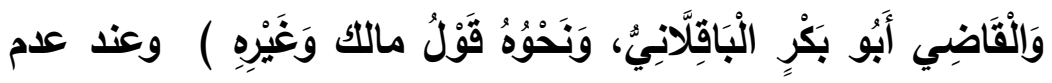
معرفة قائله يقول : ولم أدر من ذكره كما قاله في القول الثالث • عشر

r) يعقب أحياناً علي بعض الأدلة فنراه مثلاً في القول الخامس أن

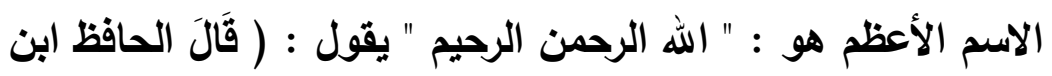

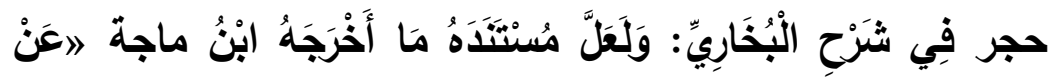

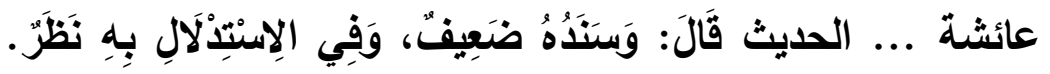

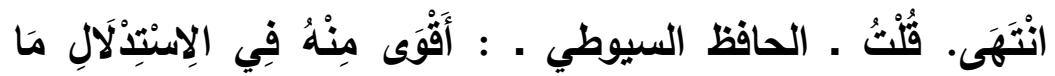

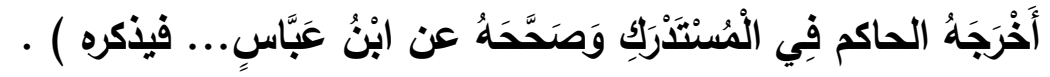

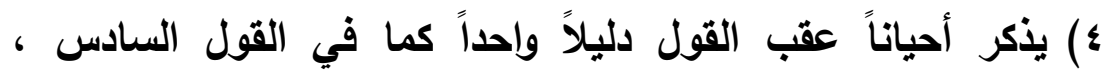
والسابع ، وأحيانا أكثر من دليل كما في القول الرابع ـ ذكر دليلين . والقول العاشر ـ ذكر دليلين ـ والقول الرابع عشر ـ ـذكر ثثلاثة أدلة .

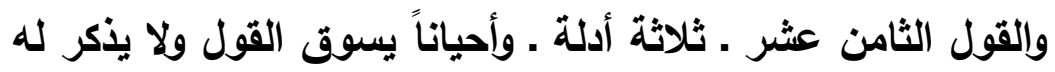
دليلاً كالقول الخامس عشر قال : كلمة التوحيد نقله عياض. 


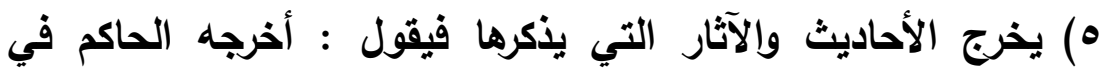

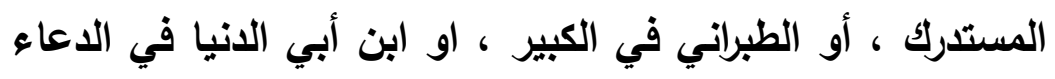

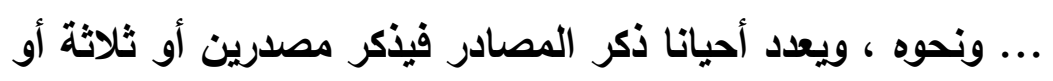

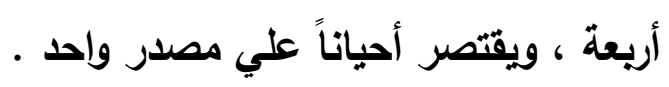

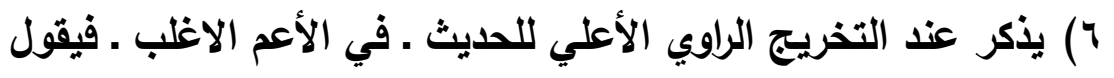

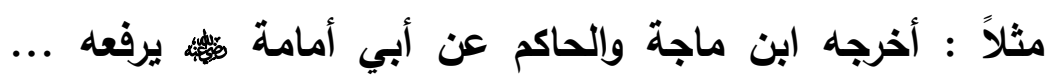

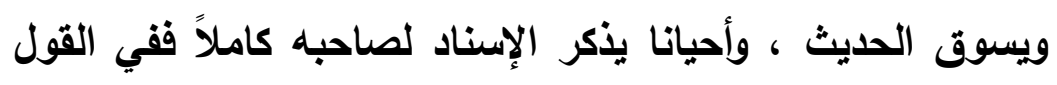

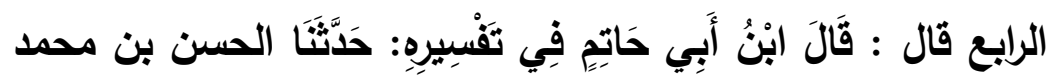

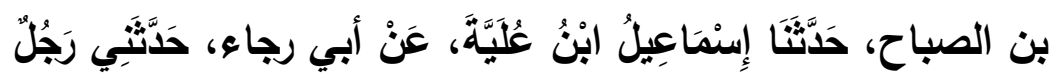

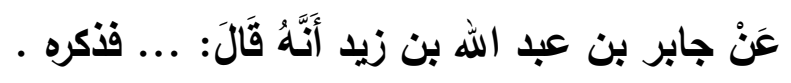
( يراعي اختلاف الألفاظ عند التخريج ففي القول الحادي عشر قال:

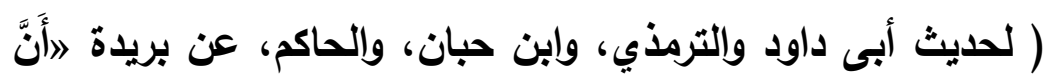
رَسُولَ اللَّهِ

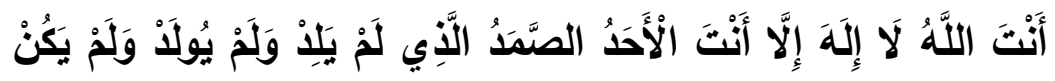

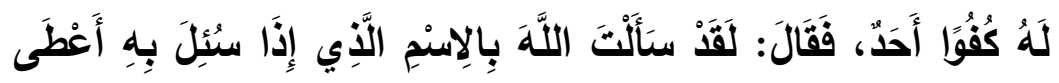

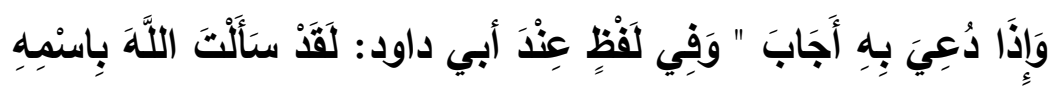

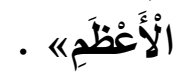




\section{الاملب الثاني : همادروه :}

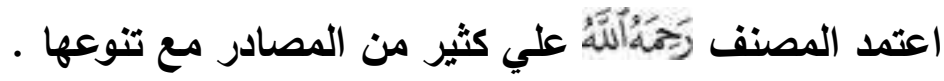

- ففي التفضير : منه ما نص عليه صراحة ، ومنه ما أخرج منه ولم

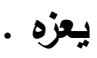

أ- جامع البيان لابن جرير الطبري فيقول : وأخرج ابن جرير من فن فئ

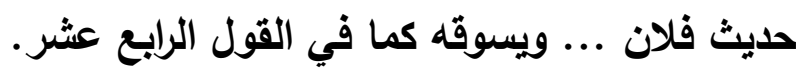

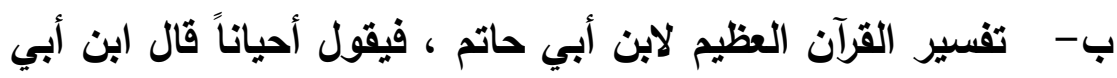
حاتم في تفسيره ... ويذكره كما في القول الرابع ، ويقول أحياناً أخرج ابن ابي حاتم عن فلان ... ويسوقه كما في القول الرابع

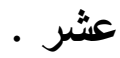

ت- مفاتيح الغيب للفخر الرازي فيقول : نقله الفخر الرازي عن فلان

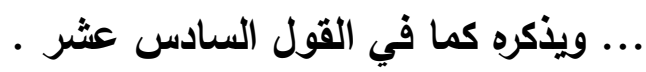

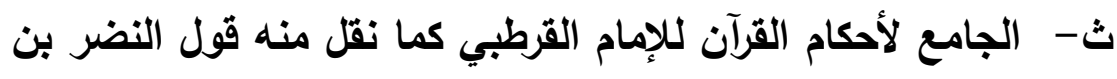

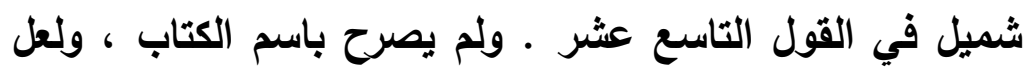

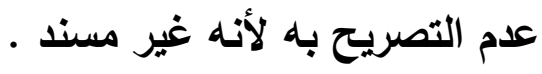
- وفي المديث : نص صراحة على عدة مصادر وهي : أ- السنن للإمام أبي داود السجستاني كما في القول الثامن ، وإلحادي عشر فيقول : لحديث أبي داود... وساقه .

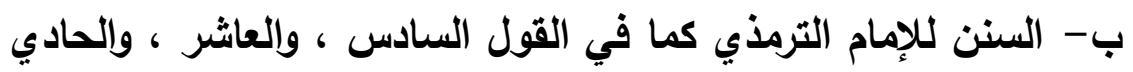
عشر فيقول : لحديث الترمذي ... وساقه . 
ت- السنن للإمام النسائي كما في القول الرابع عشر فيقول: لحديث النسائي ... وساقه.

ث- السنن لابن ماجة كما في القول الخامس ، والسابع ، والحادي عثر فيقول: لحديث ابن ماجة ... وساقه .

ج- المسند للإمام أحمد كما في القول الثامن فيقول: لحديث أحمد ... وساقه

ح- الدعاء لابن أبي الانيا كما في القول الرابع قال : وَقَالَ ابْنُ أَبِي

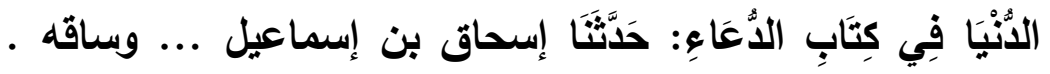
وفي القول الثاني عشر قال : واخرج ابن ابي الانيا عن عائشة ... وساقه

خ- صحيح ابن حبان كما في القول الأول : فنقل منه تأويل ابن حبان للأعظمية ، والقول الثامن قال : لحديث ابن حبان ... وساقه . دـ المعجم الكبير للطبراني كما في القول الثالث عشر قال : أخرج • الطبراني في الكبير

ذ- المستدرك للإمام الحاكم فقال: أخرجه الحاكم في المستدرك كما في القول الخامس ، ويقول لحديث الحاكم كما في القول السابع ، والثامن ، والحادي عشر ، والثاني عشر، واليرابع عشر ـ أخرج منه

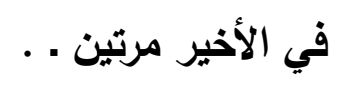

ر- - مسند الفردوس للايلمي كما في القول الخامس قال : وَفِي مُسنتَّ

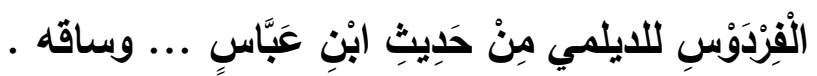




\section{- كتب الشروع والتواريخخ :}

كفتح الباري كما في القول الخامس فقال :( قَالَ الحافظ ابن حجر فِي

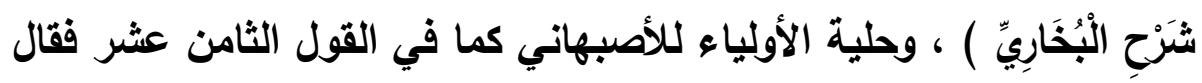

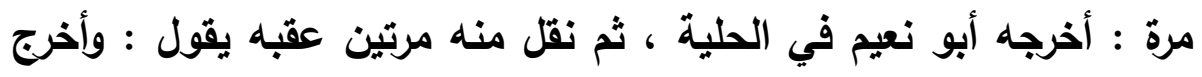

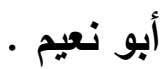

وغيرها من المصادر التي نقل منها ولم ينص عليها صراحة . 


\section{المبث الثالث : وصف النسخ}

اعتمدت في تحقيق المخطوط علي ثلاث نسخ ، منها نسختان خطيتان ،

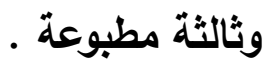

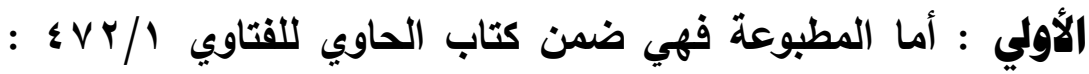
V I V آخر الجزء الأول من مطبوع دار الفكر للطباعة وإلنشر، بيروت - لبنان

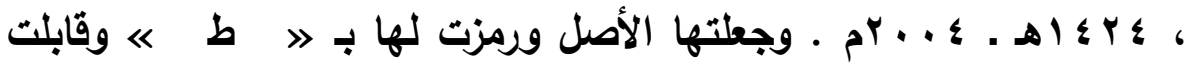

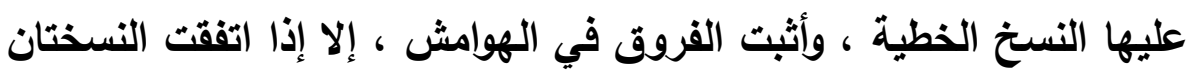

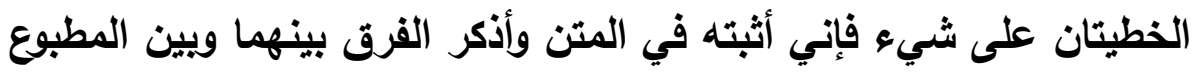

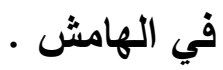

الثانية : نسخة مخطوطة مستقلة مصورة من موقع مخطوطات الأزهر الثريف بمصر ، عدد أوراقها (r) ورقات ، كل ورقة وجهان ، وخطها

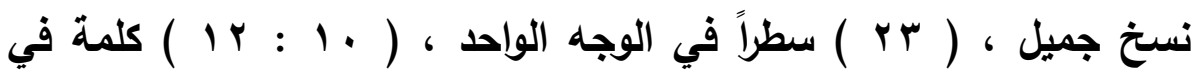

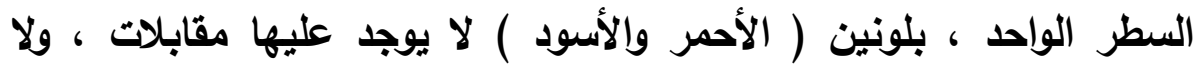

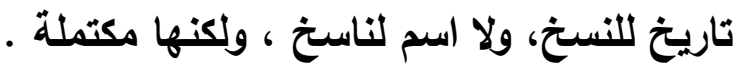
كتب في مقدمتها \ا الدر المنظم في اسم الله الأعظم تأليف خاتمة

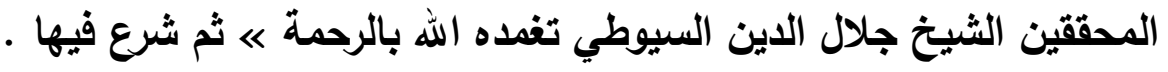
وفي آخرها : 》ا تم الكتاب بحمد الله وعونه ، وصلى الله على سيدنا

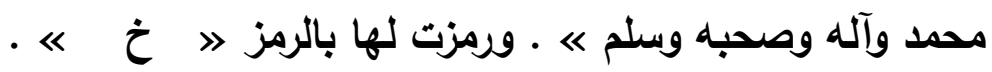


الثالثة : نسخة مخطوطة ضمن كتاب الحاوي للفتاوي للحافظ

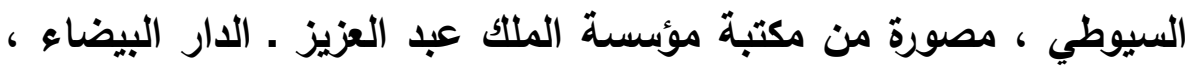

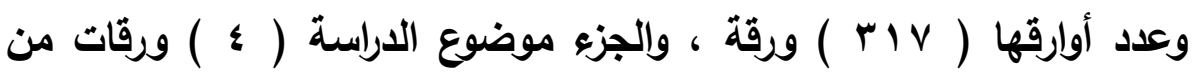

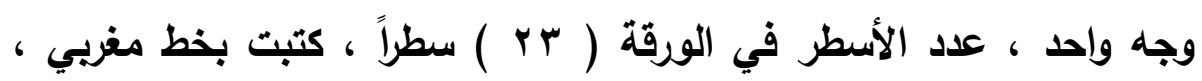

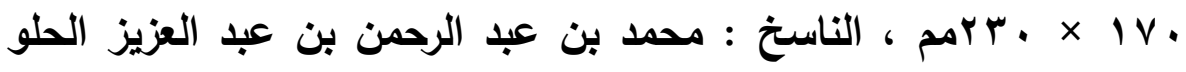

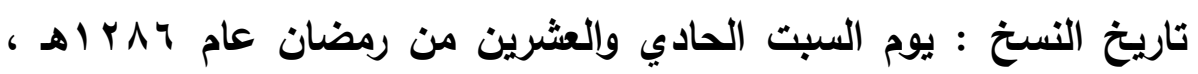

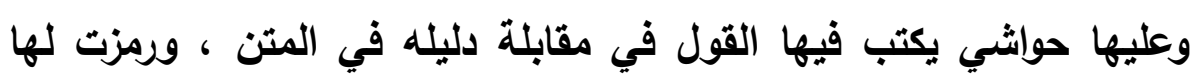

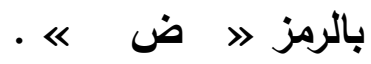




\section{I ||1111]}

\section{صورة هن المطوطات >}

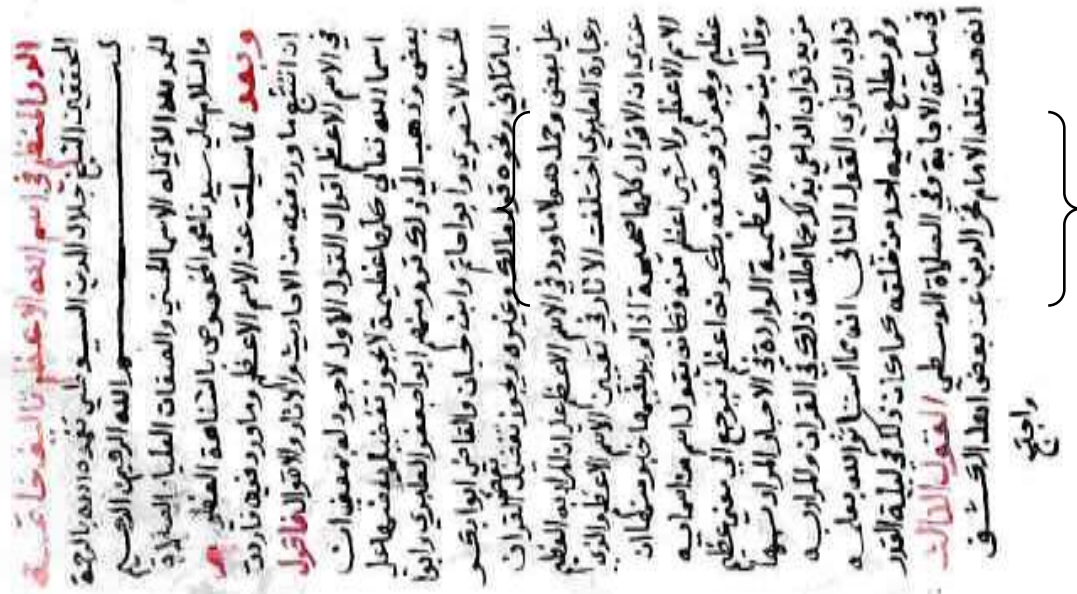

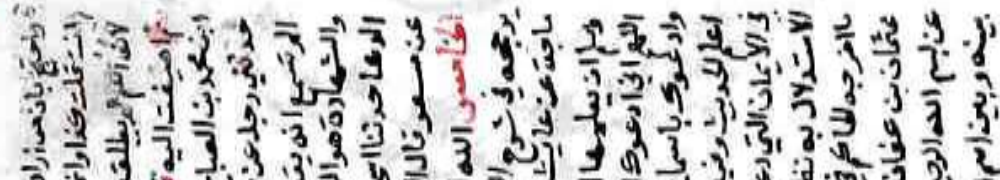

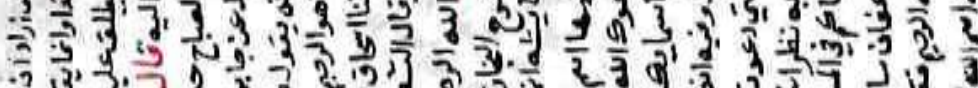

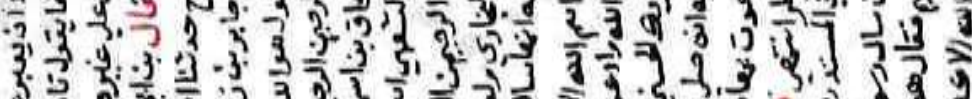

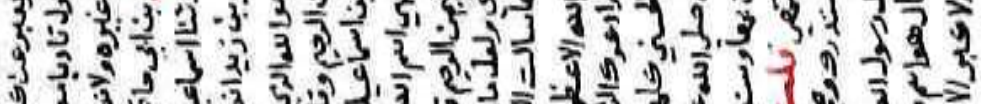

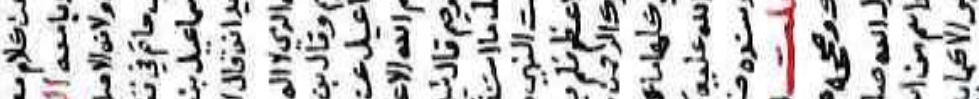

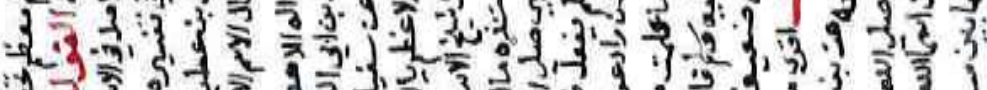

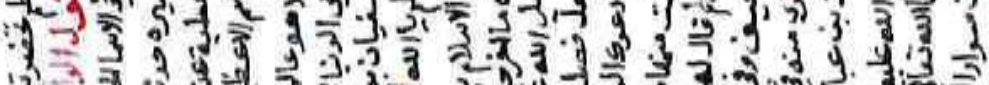

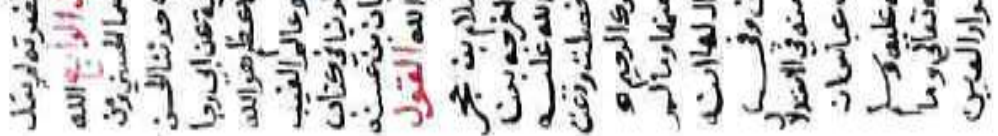

$$
\text { الصفحة الأولى من " خ " الم }
$$




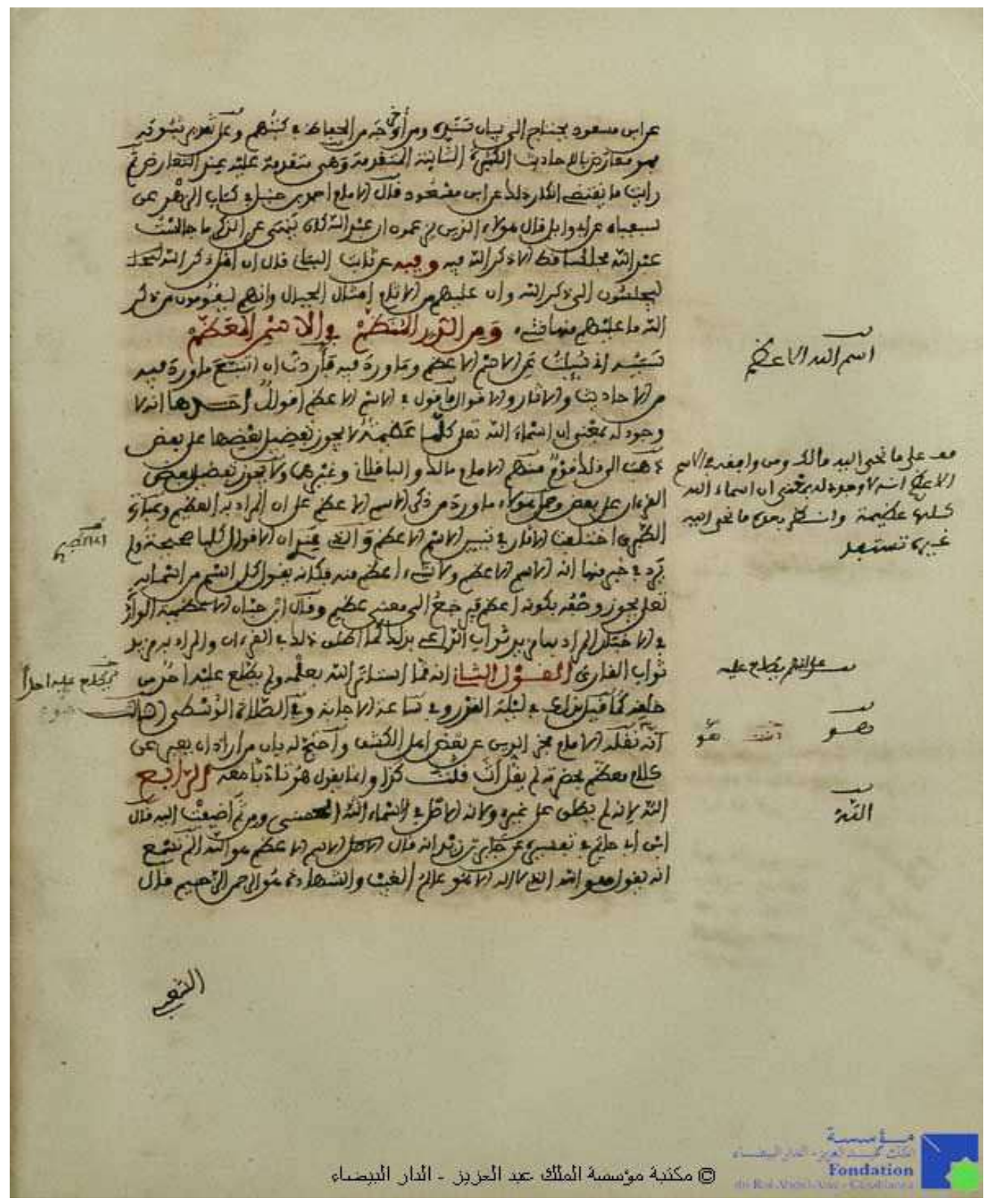

\section{الصفحة الأولى من " ض}




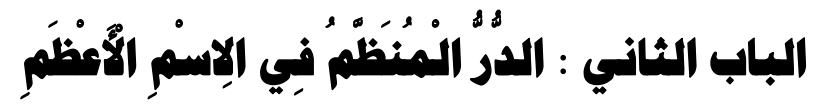 \\ تمقيق ونمرية ودراسة

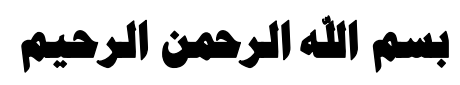

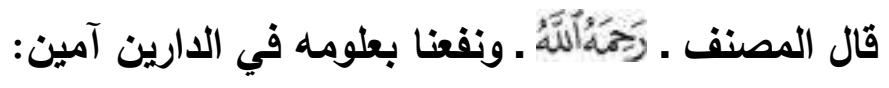

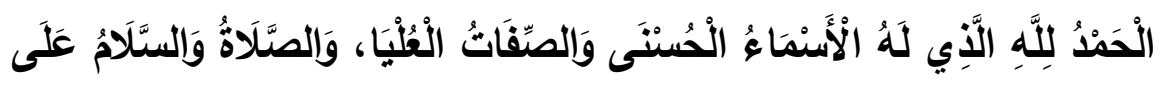

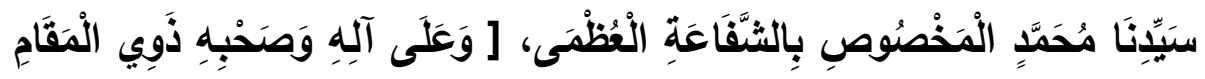

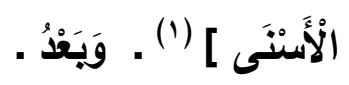

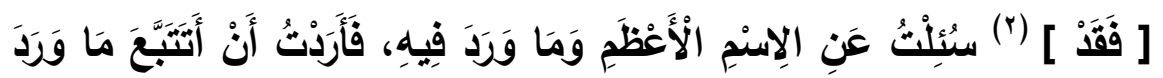

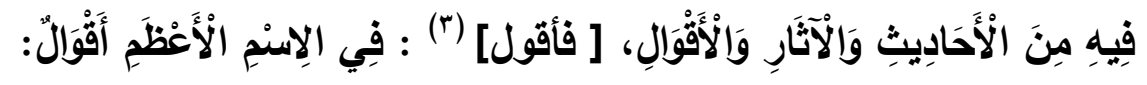

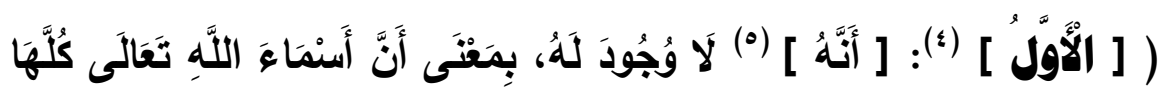

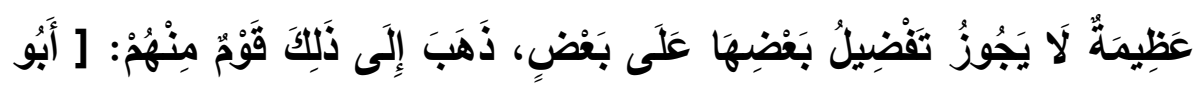

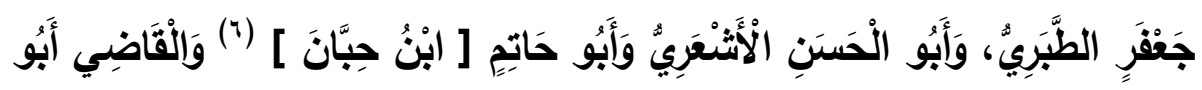

(') سقطت من 》 خ " وفي » ض « بدون المقدمة لأنها جزء من الكتاب فاكتفى بمقدمة

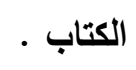

. لم

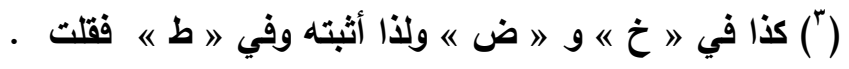

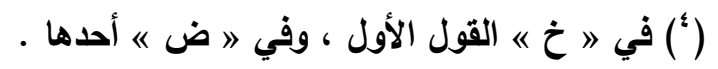

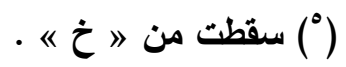

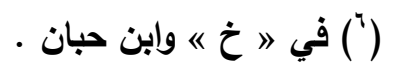




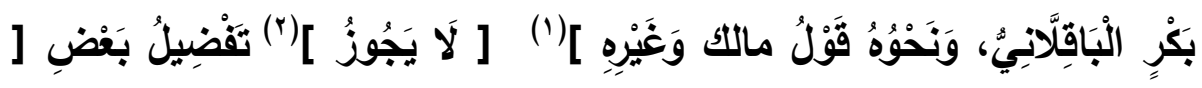

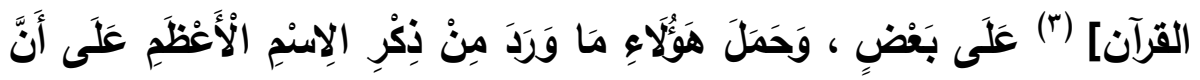

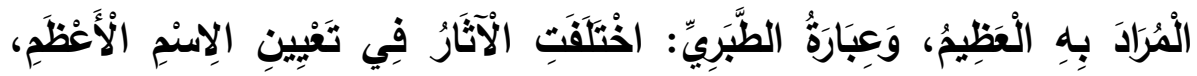

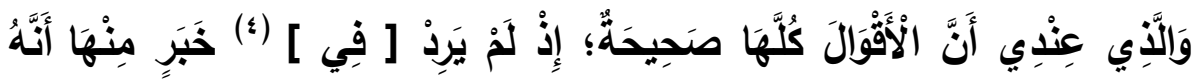

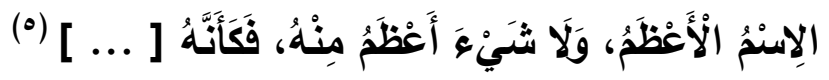

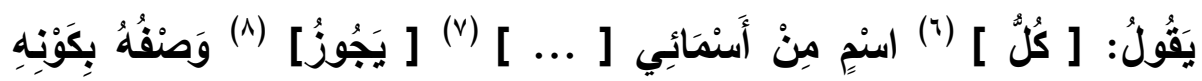

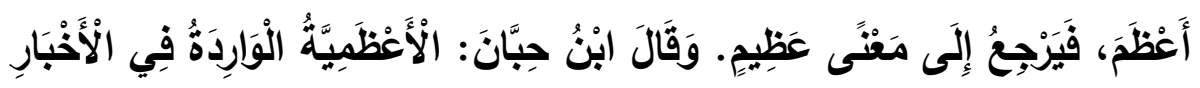

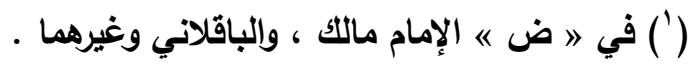

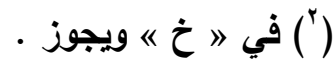

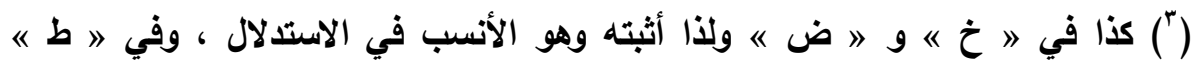
الأسماء فاء

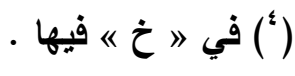

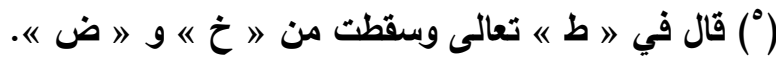

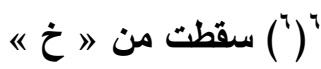

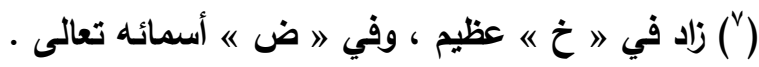

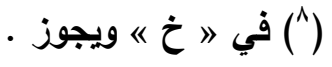




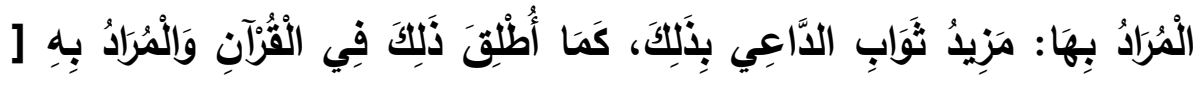

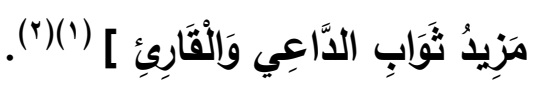

(') في " خ خ ثواب القارئ ، و في " ض 《 مزيد ثواب القارئ . قلت : وهو الأنسب •للمعنى

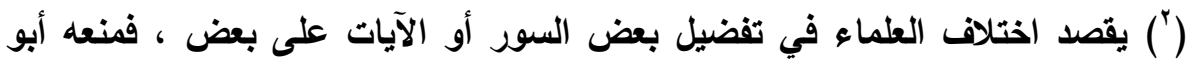

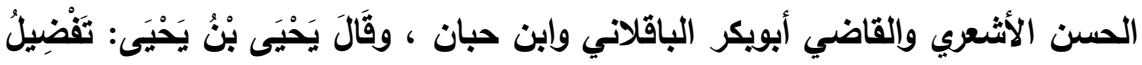

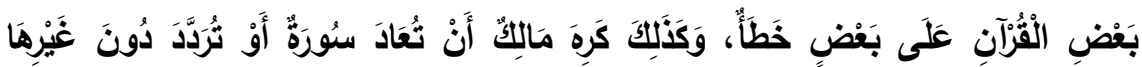

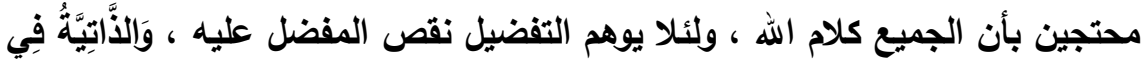

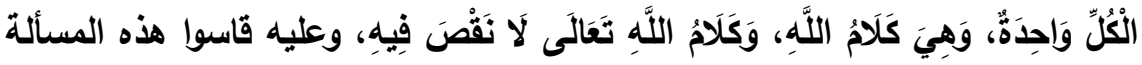

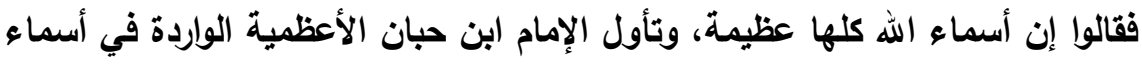

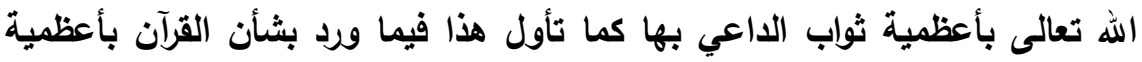

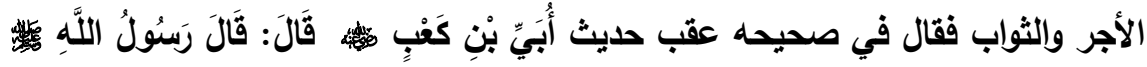

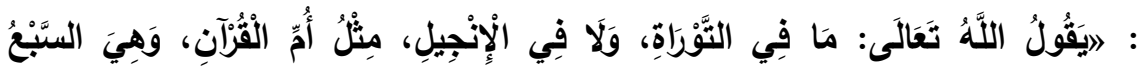

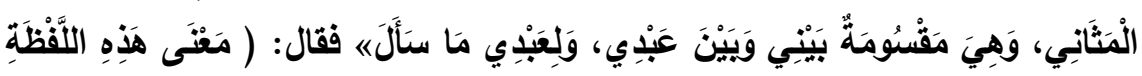

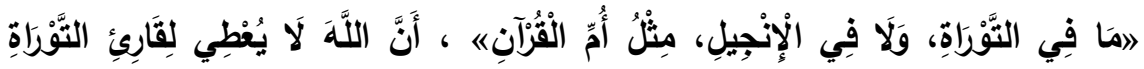

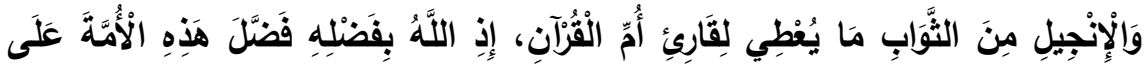

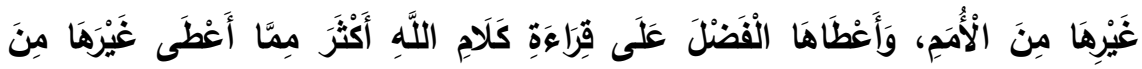

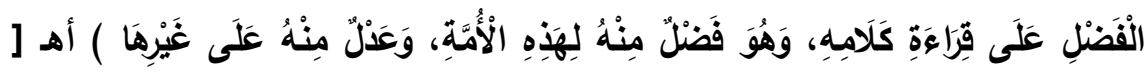

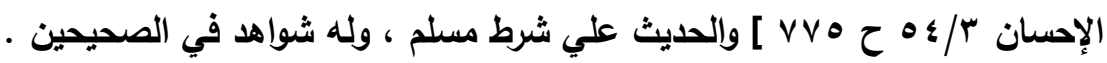

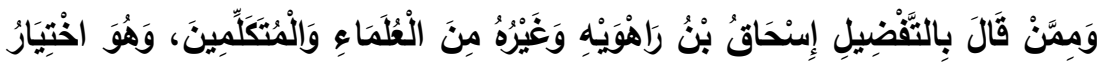

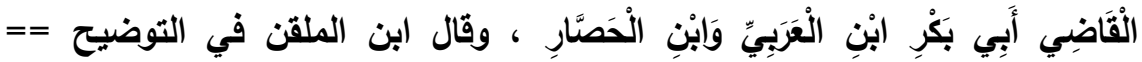




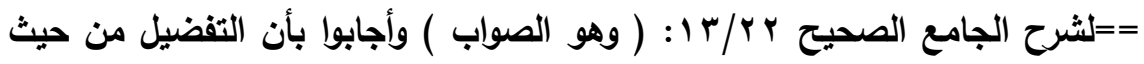

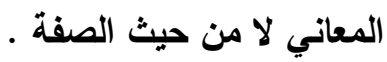

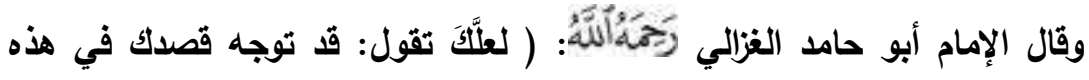

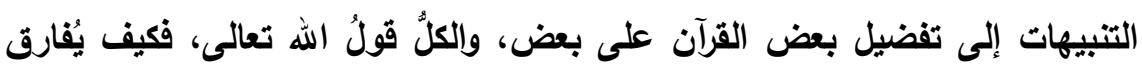

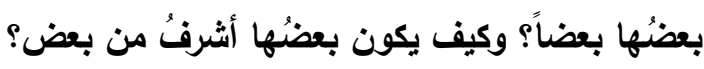

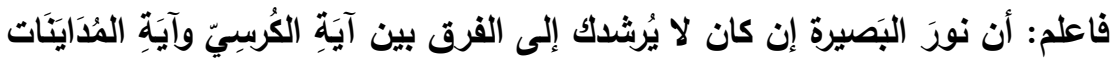

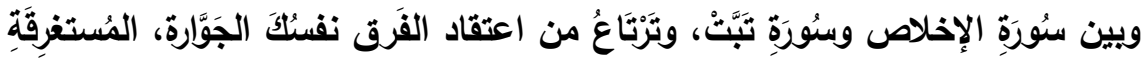

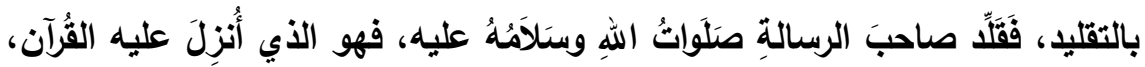

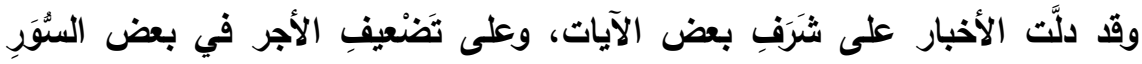

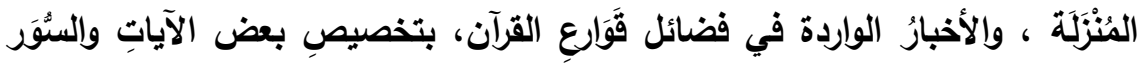

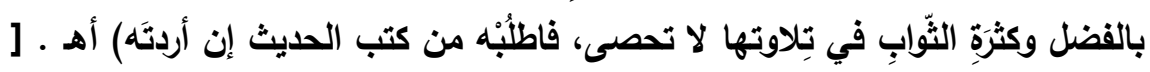

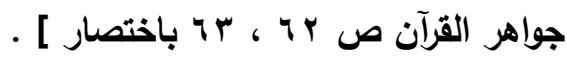

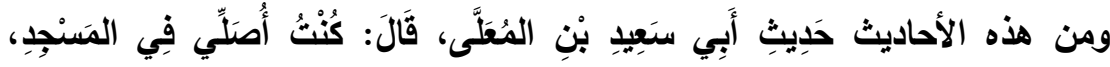

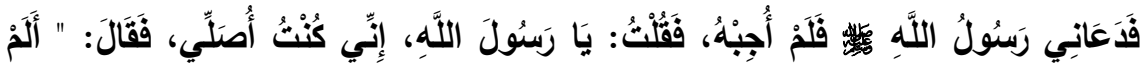

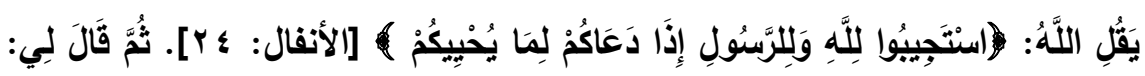

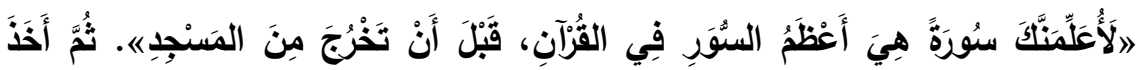

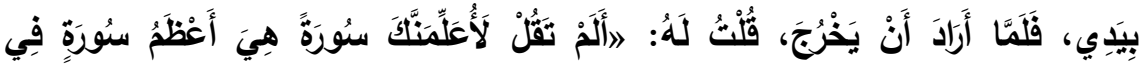

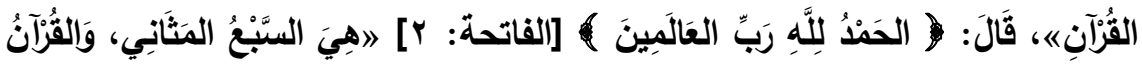

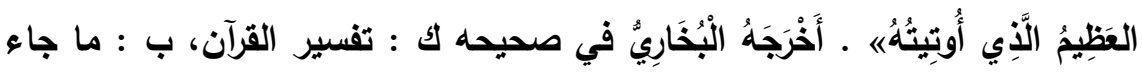

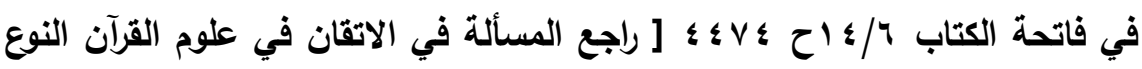

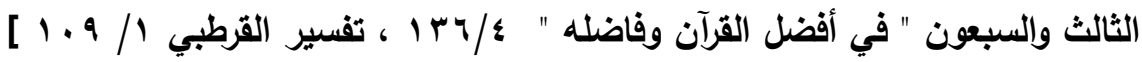




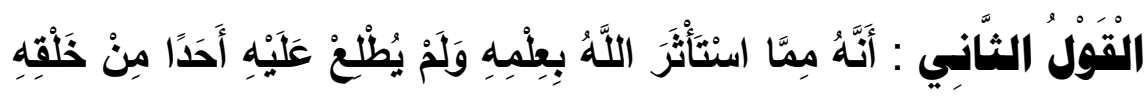

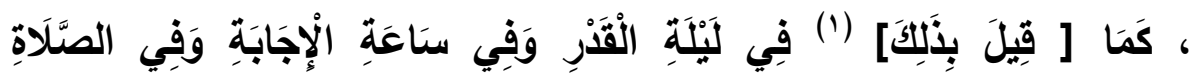

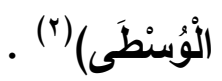

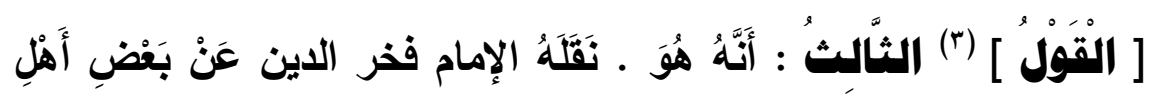

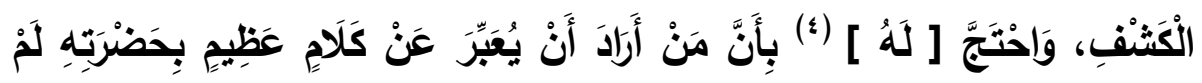

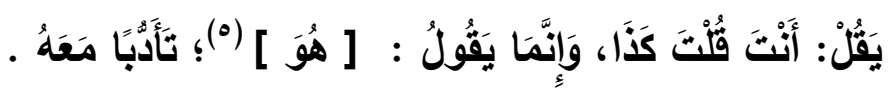

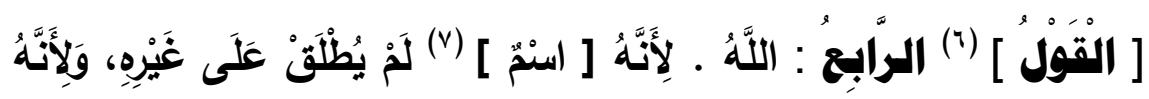

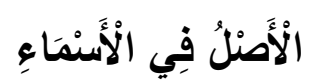

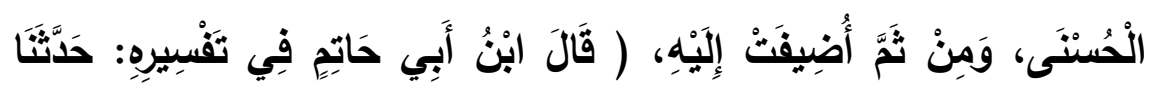

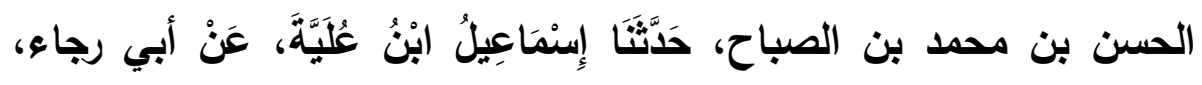

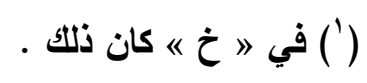

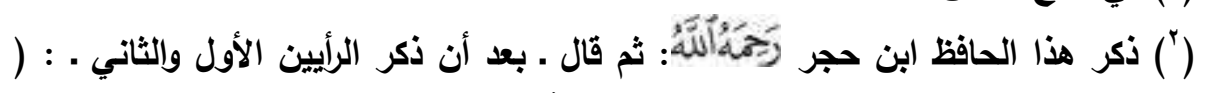

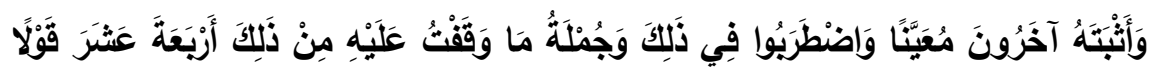

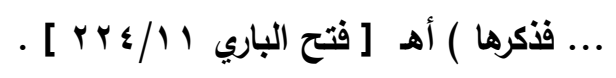

$$
\text { (") }
$$

\section{\& $1 \leqslant$}

جلمة كلية اصول الدين والدعوة / العدد السادس والثلاثتون ^1 ا ب بم ـ الجزء الاول 


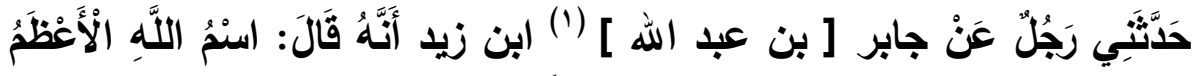

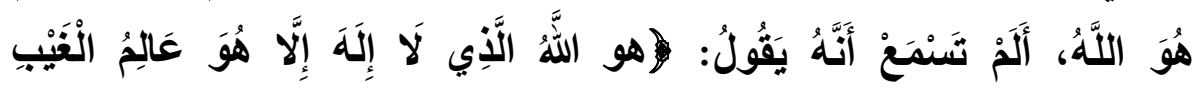

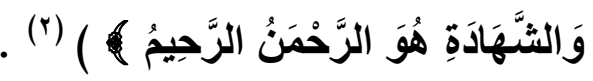

(') سقطت من " خ " وفي " ض " بدون ذكر الإسناد فقال عن جابر بن زيد .

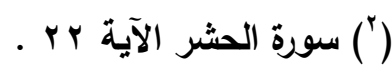

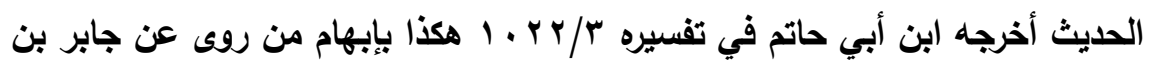

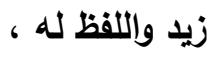

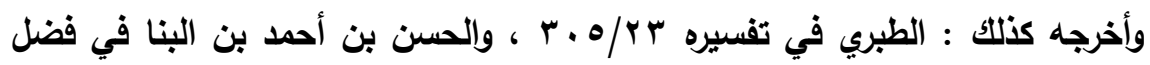

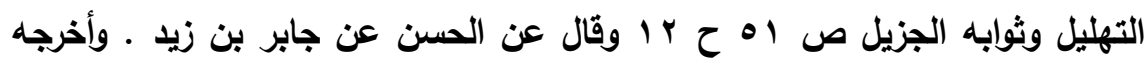

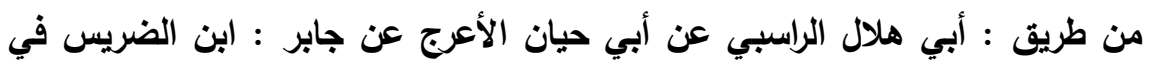

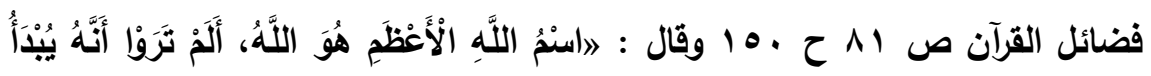

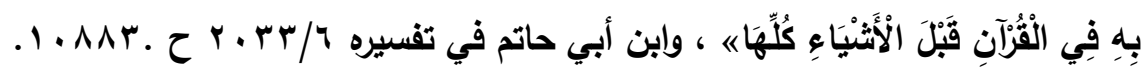

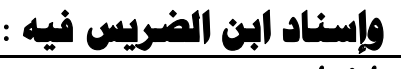

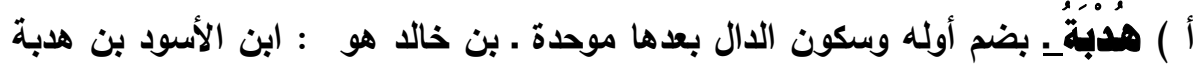

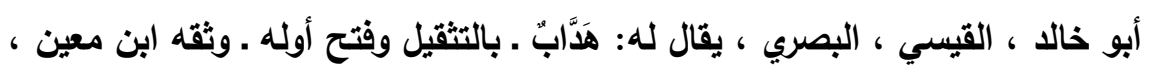

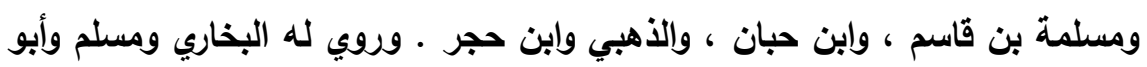

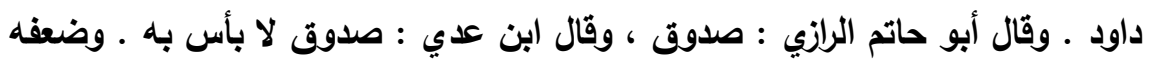

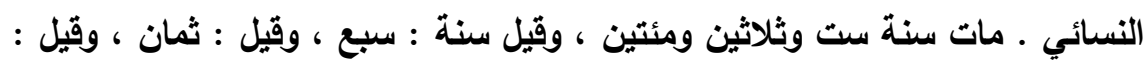

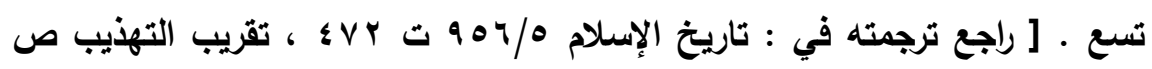
ت

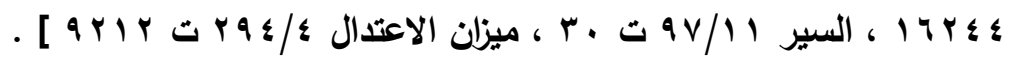


كe قلت : انفرد النسائي بتضعيفه . وقال الحافظ الذهبي : ( لا وجه لقول

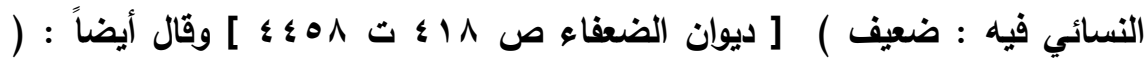

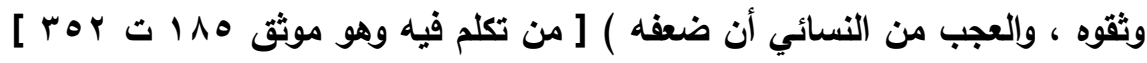

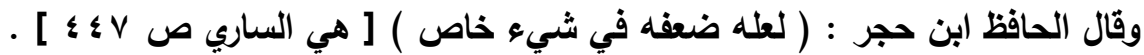
وعليه فهو : ثقة .

ب ) أبو هلال الراسبي هو: محمد بن سُتَيْم · بضم السين المهملة، وفتح اللام،

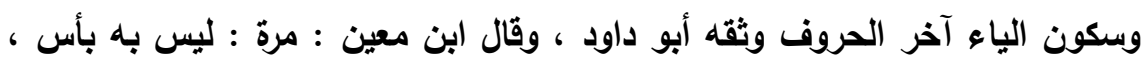

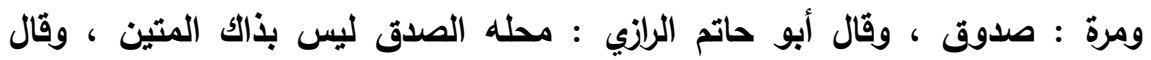

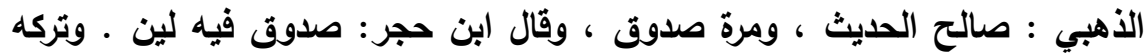

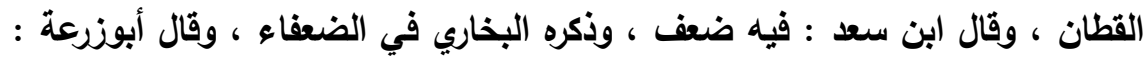

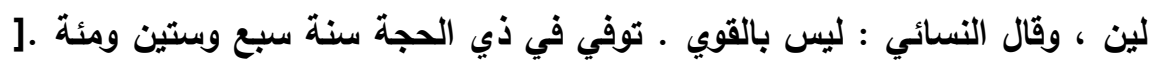

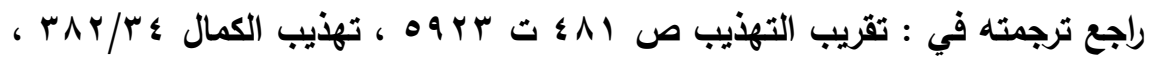

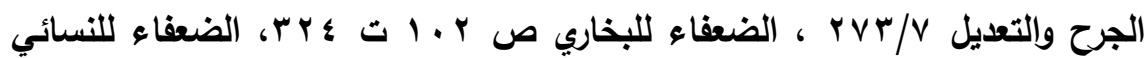

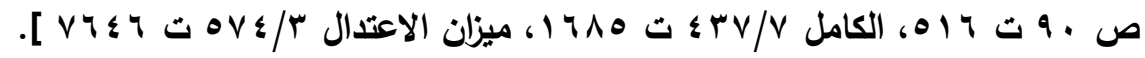
كع قات : هو حسن الدديث مضطرب في حديث قتادة خاصة ، سئل ابن معين:

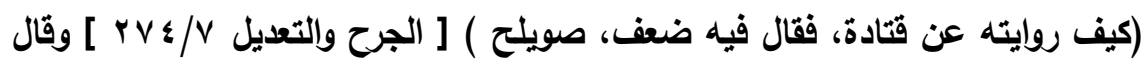

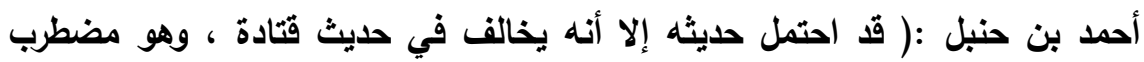

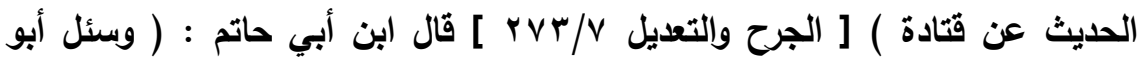

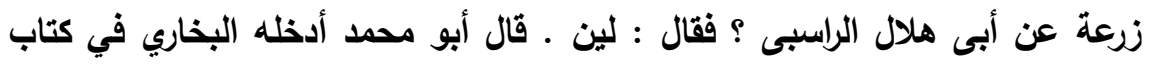

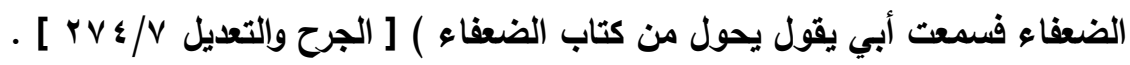

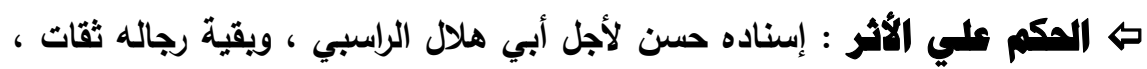

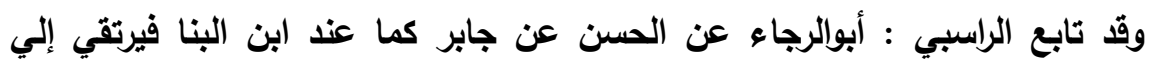

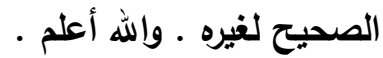




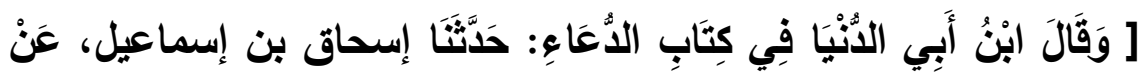

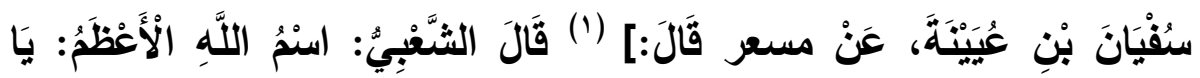
اللَّةُ.

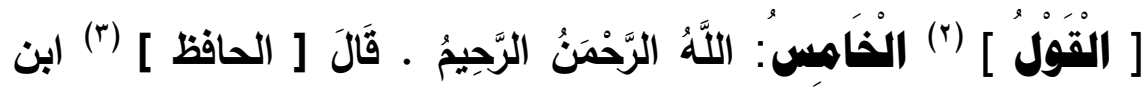

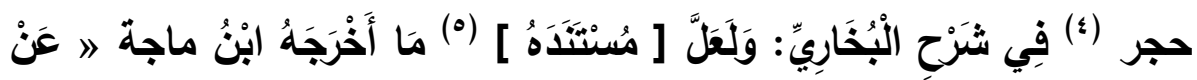

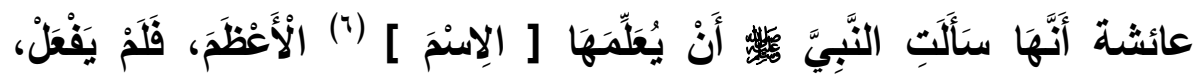

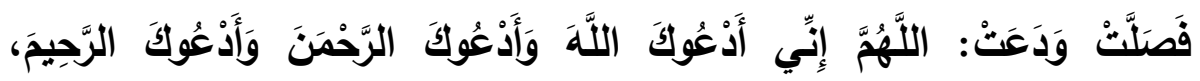

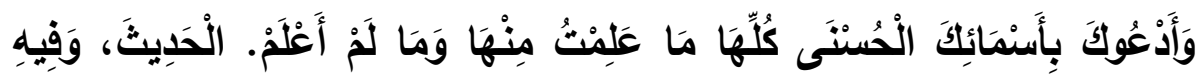

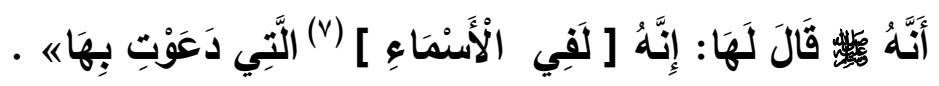

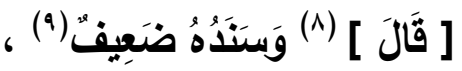

$$
\begin{aligned}
& \text { (') سقطت من " ض ". }
\end{aligned}
$$

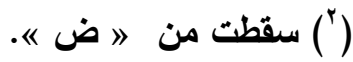

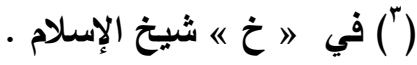

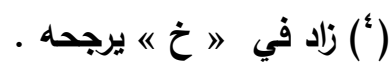

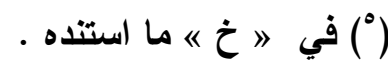

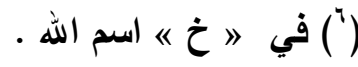

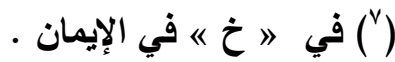

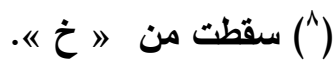

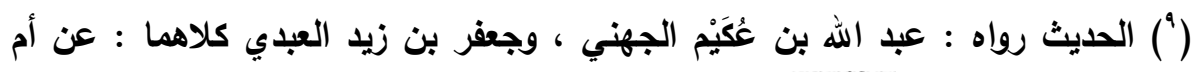

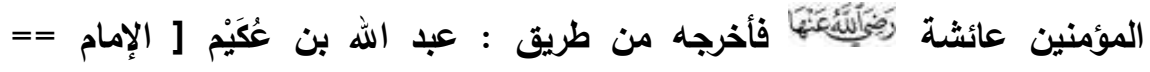




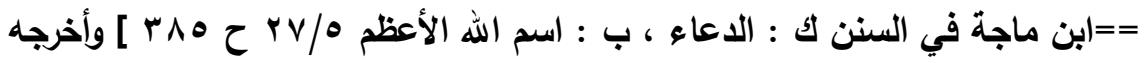

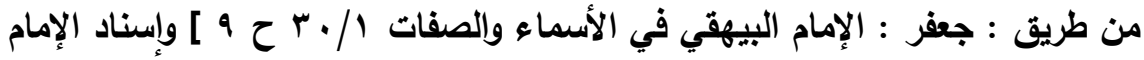
ابن ماجة ضعيف فيه : أبو شيبة ، قال الحافظ ابن حجر : ( يحتمل أن يكون أحد

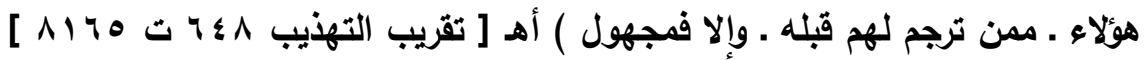

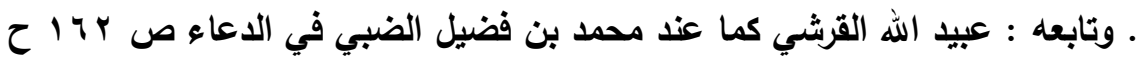
ه ] ـ وفيه : عبد الرحمن ابن إسحاق بن الحارث : متفق على تضعيفه وقال أحمد :

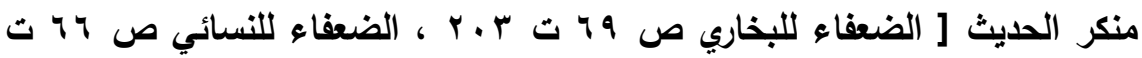

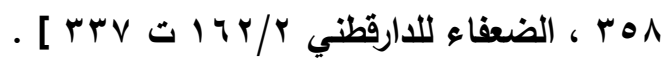
وإسناد الإمام البيهقي فيه : صالح المري : متفق علي ضعفه ، وقال البخاري : منكر

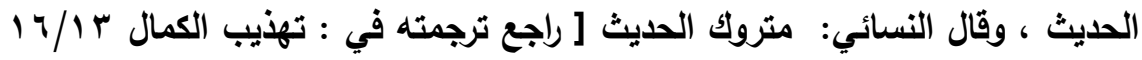

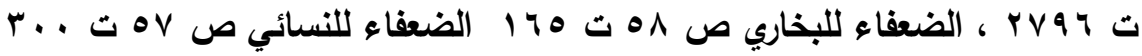

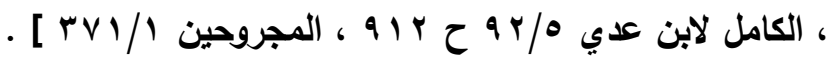

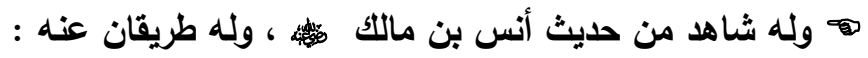

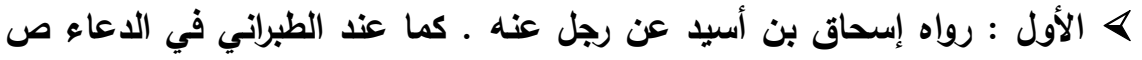

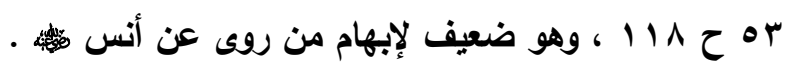
\& الثاني : رواه محمد بن عبد الله العصري عن غالب القطان عنه ـ كما عند

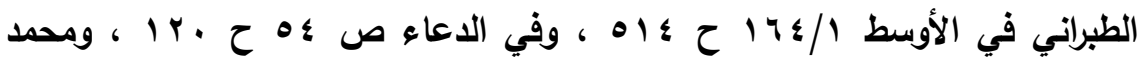

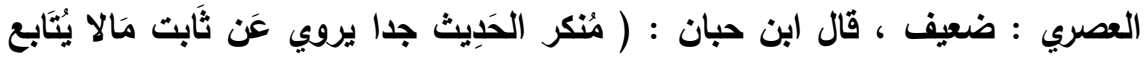

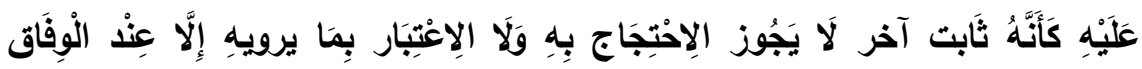

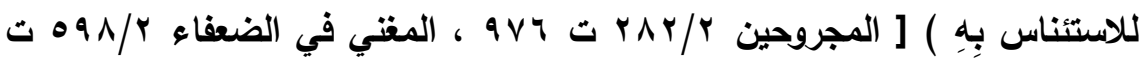
. [ ० TV 


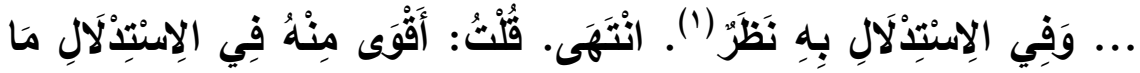

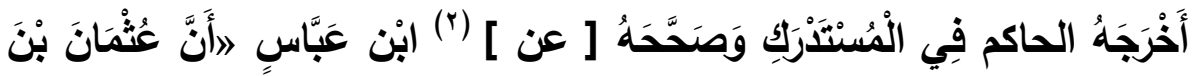
عَفَّانَ سَأَلَ رَسُولَ اللَّهِ

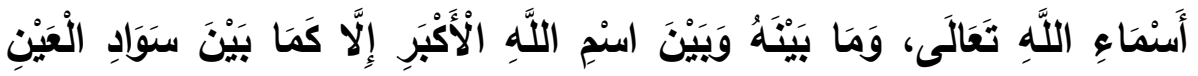

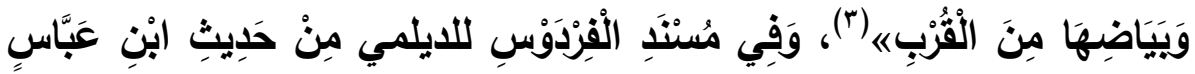

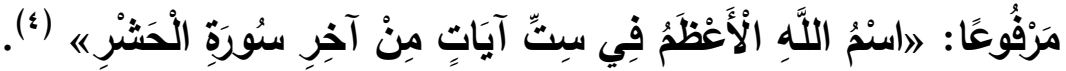

(') قلت : لأنه ليس صريحا أنه في الأسماء المذكورة لقول أم المؤمنين : (ََأَدْعُوَكَ

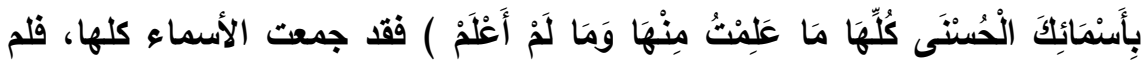

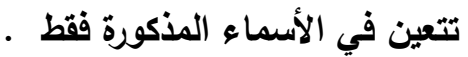

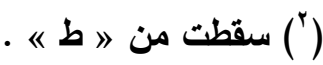

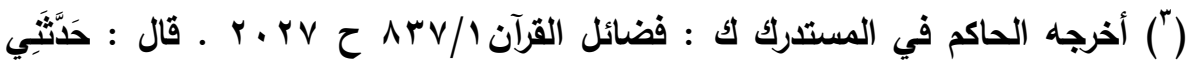

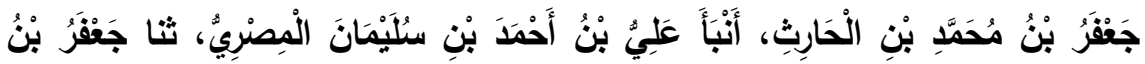

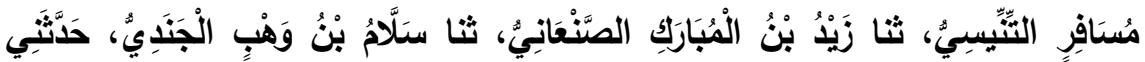

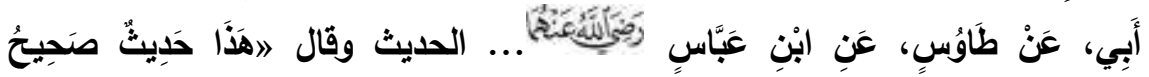

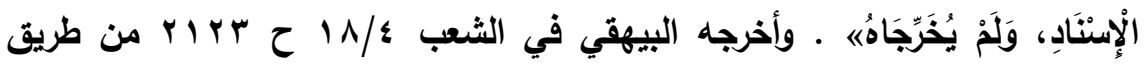

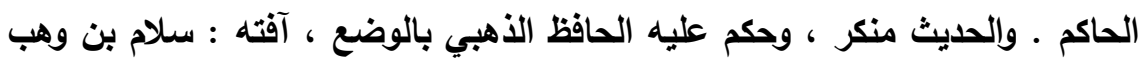

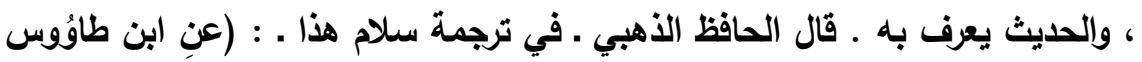

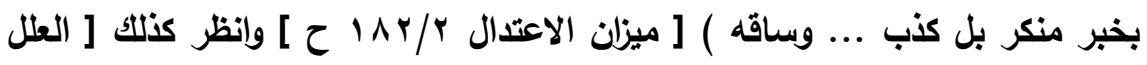

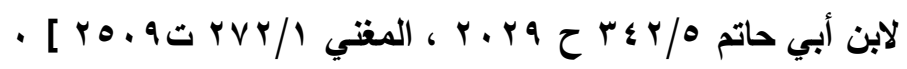

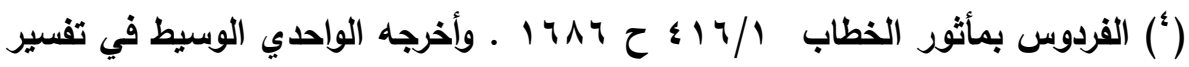

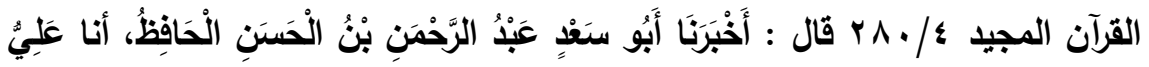

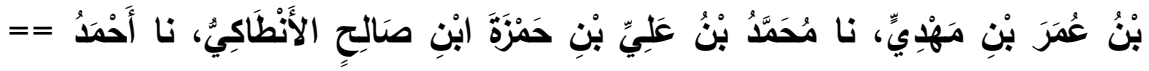




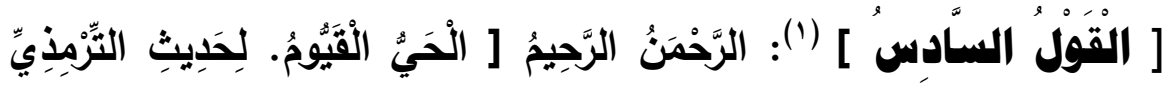

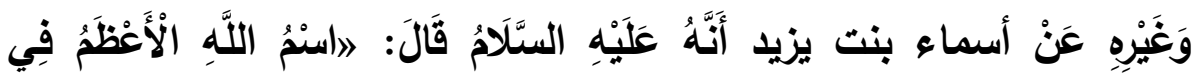

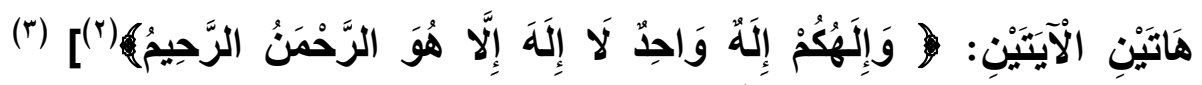

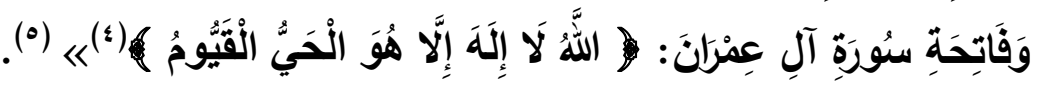

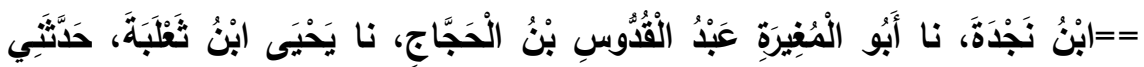

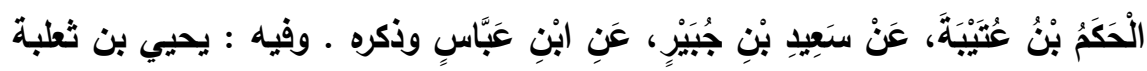

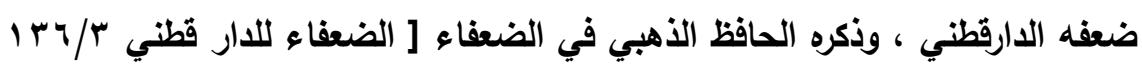

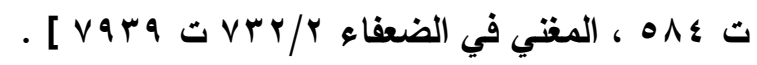
(') سقطت من 》 ض " ه ومن هنا حتى آخر المخطوط لم يعدد الأقوال بل يضع فاصلاً في

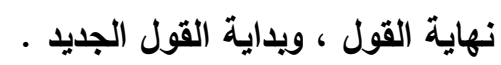

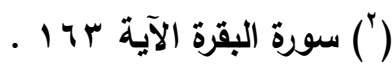

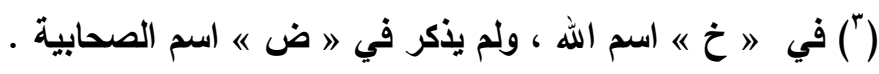

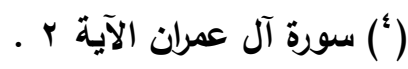

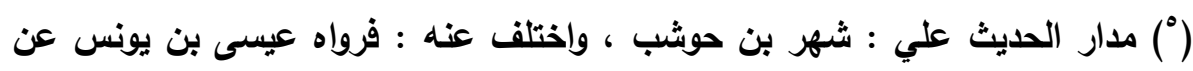

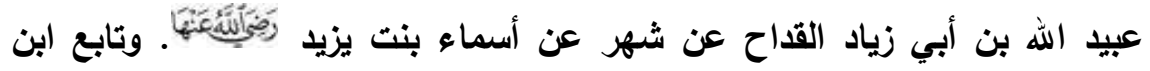

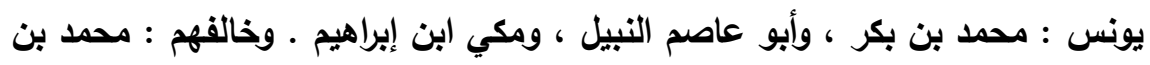

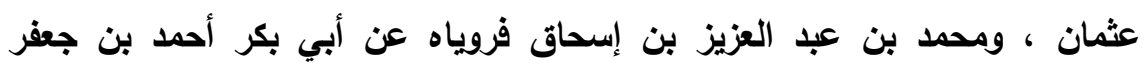

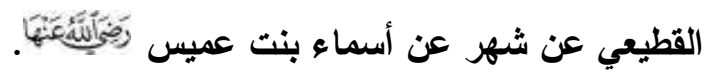

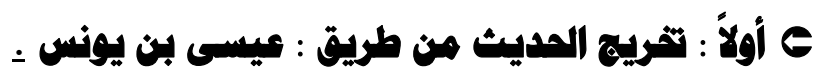

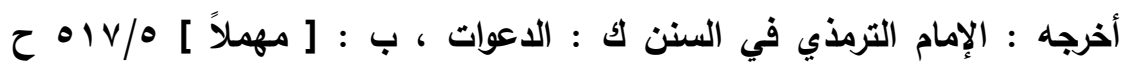

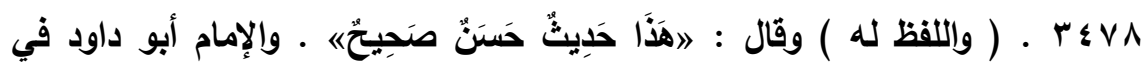

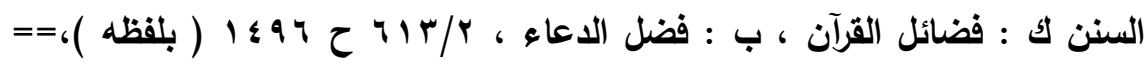
$\leq q$.

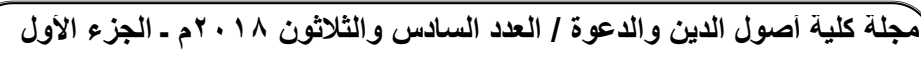




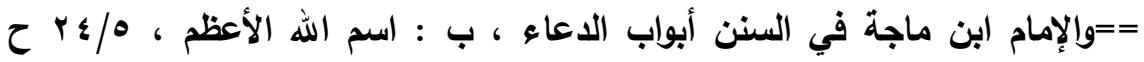

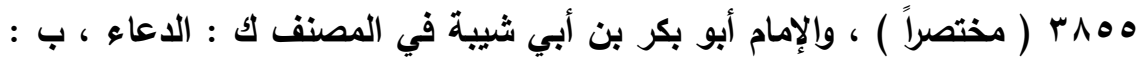

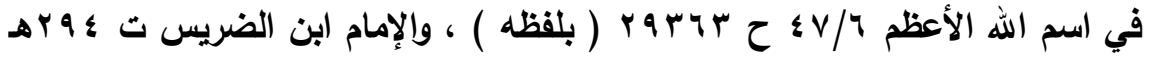

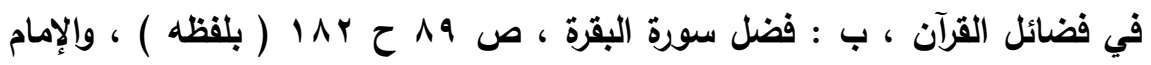

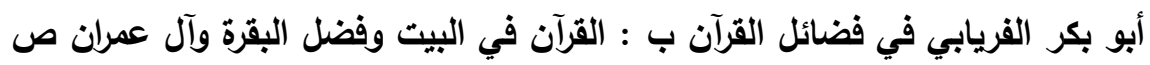

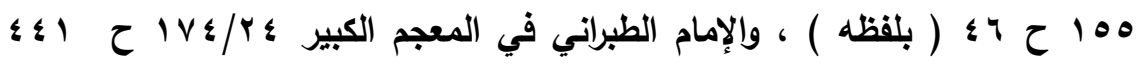

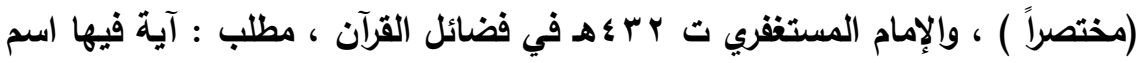

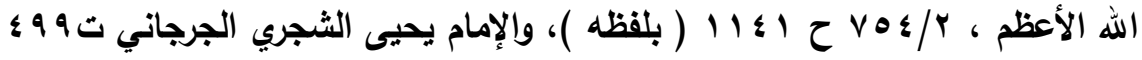

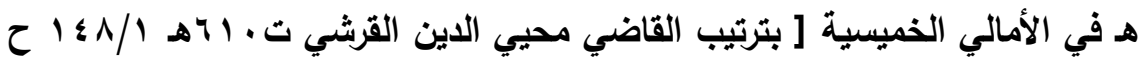
.

\section{C ثانيا : ثخريج المديث طريق : هممد بن بكر .}

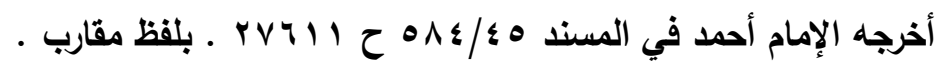
C ثالث) : تخريج المديث من طريق : أبي عاصم النبيل .

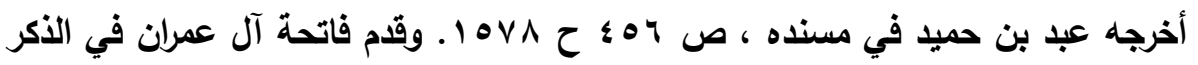

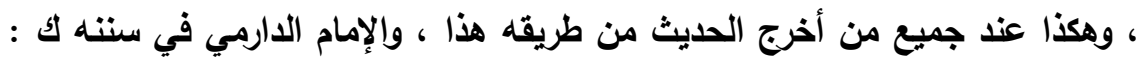

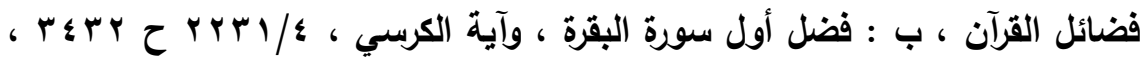

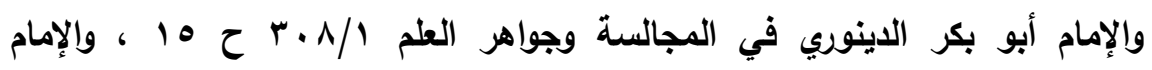

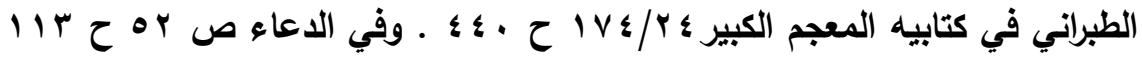

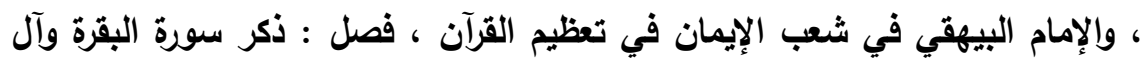

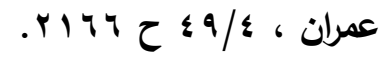
ع رابها : تثريه المديث من طريق : مكي بن إبراهيم . 


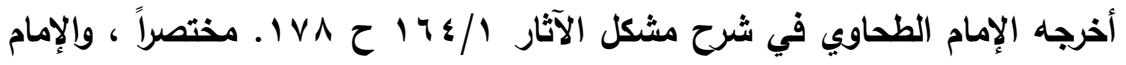

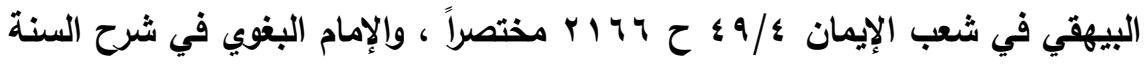

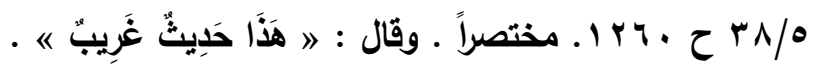

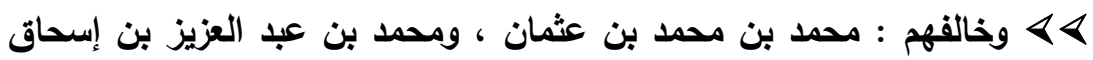

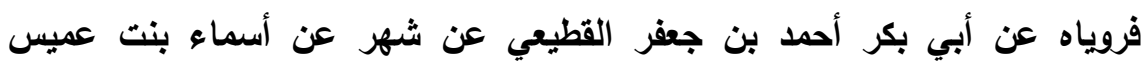

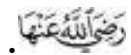

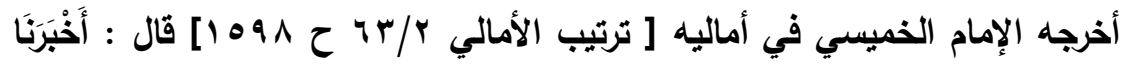

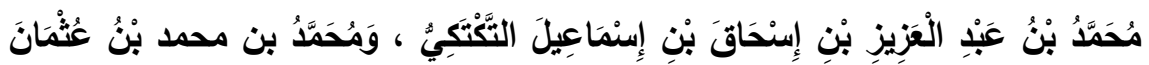

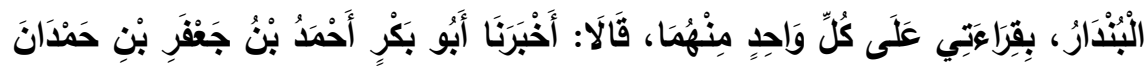

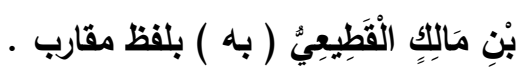

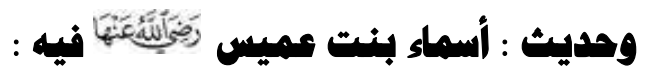
( أ أبو بكر أهمد بن جمفر بن همدان ، القطيعي . بفتح القاف وكسر الطاء المهملة وسكون الياء المنقوطة من تحتها باثتين وفي آخرها العين المهملة، هذه به بهاه النسبة إلى القطيعة، وهي مواضع وقطائع في محال متفرقة ببذاد، منها : قطيعة

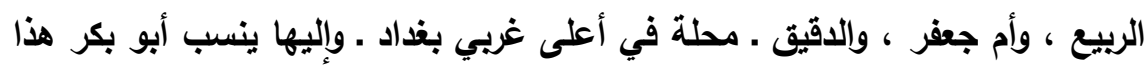

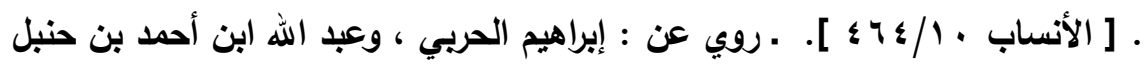

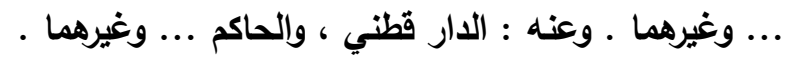
— مهلده : يوم الإثنين لثثلاث خلون من المحرم سنة أربع وسبعين ومائتين .

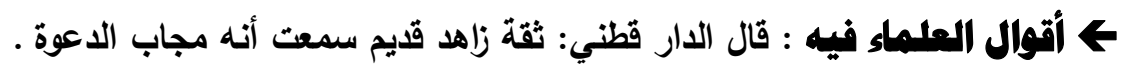

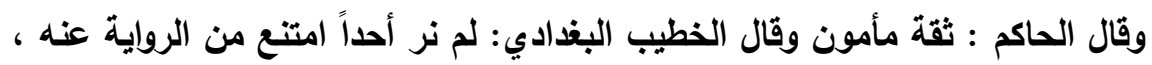

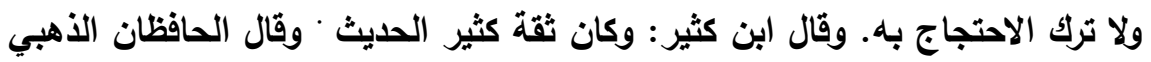
وابن حجر : صدوق في نفسه مقبول، تغير قليلا ، ووثقه ابن قطلويغا.== 


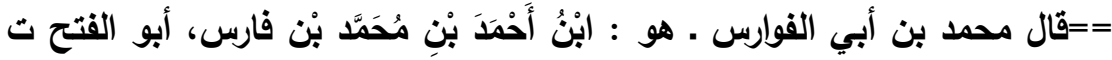

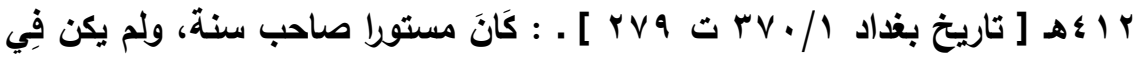

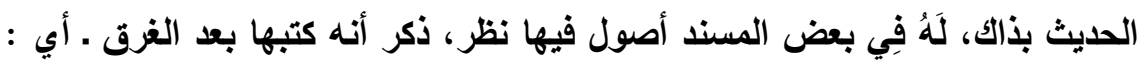
كتبه . وقال الخطيب : خلط فِي آخر عمره، وكف بصره وخرف، حتى كَانَ لا يعرف شيئا مما

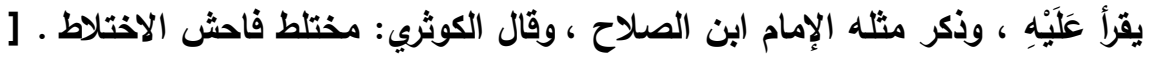

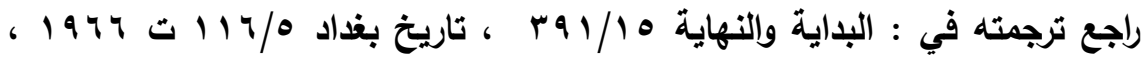

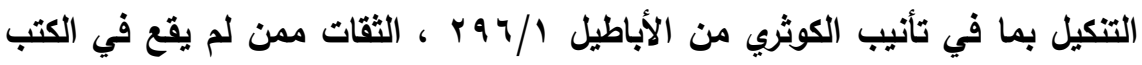

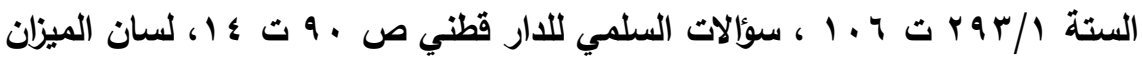

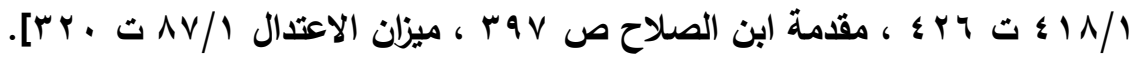

\section{كع قلت :}

ها عن القضبة الأولي التي ذكرها ابن أبي القوارب من استحداثه لنستخ بعد

$$
\text { غرق كتبه. }
$$

فقد ذكرها الخطيب فقال : (وَكَانَ بعض كتبه غرق فاستحدث نسخها من كتاب لم

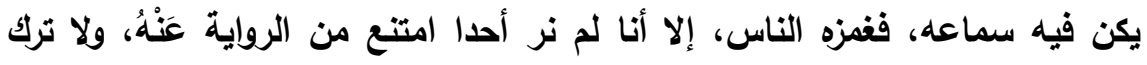

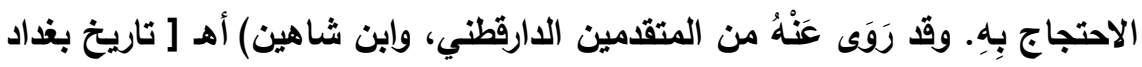

$$
\text { = }
$$

= وقال الإمام ابن الجوزي : (ومثل هذا لا يطعن به عليه، لأنه لا يجوز أن تكون

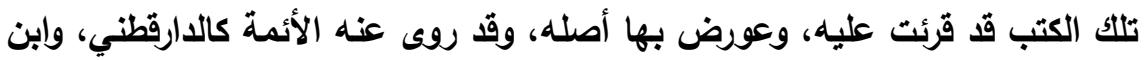

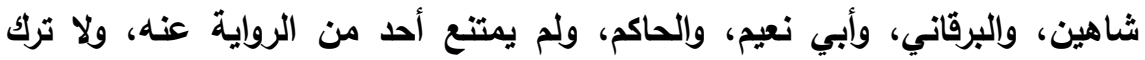

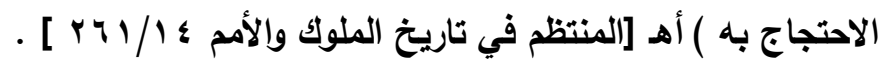

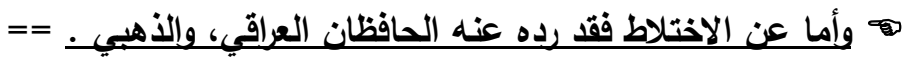


== فقال الحافظ العراقي : ( وفي ثبوت هذا عن القطيعي نظر، وهذا القول تبع فيه

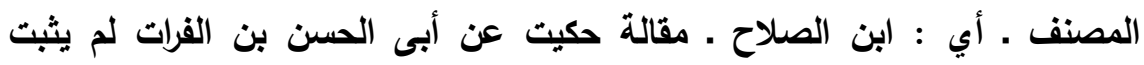

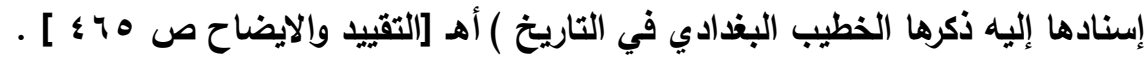

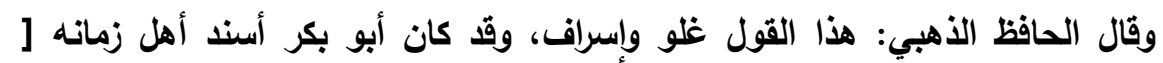

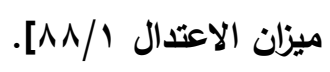

وقال الإمام المعلمي : ( ويلال على أنه غلو وإسراف أن المشاهير من أئمة النقد في

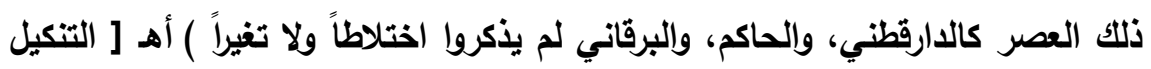

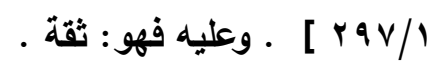

— وفاته: دفن يوم الإثثين لسبع بقين من ذي الحجة سنة ثمان وستين وثلاث مئة .

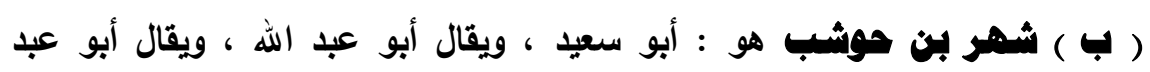

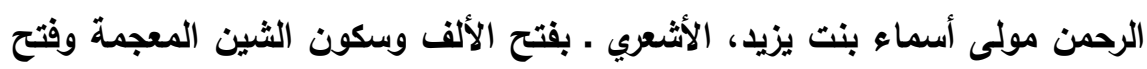

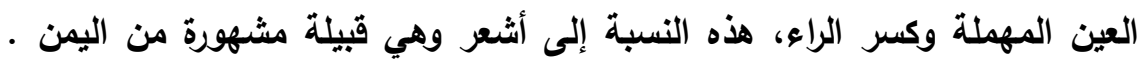

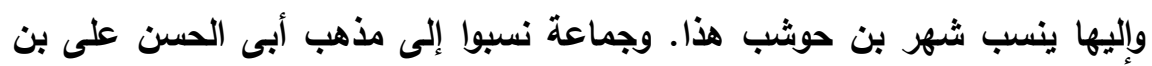

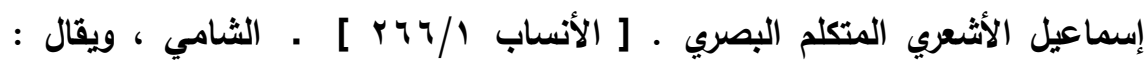

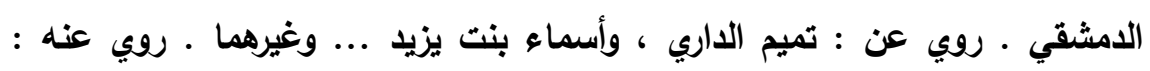

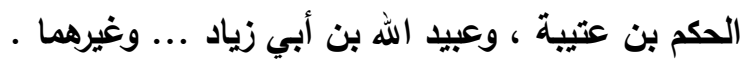

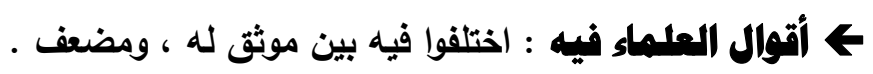

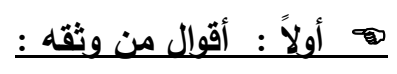

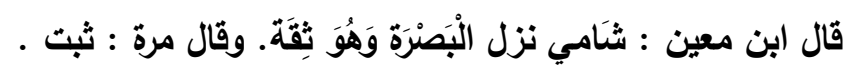

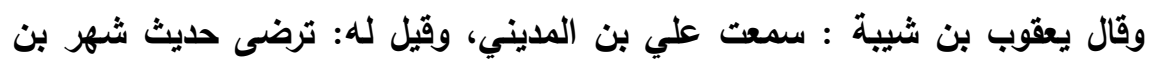

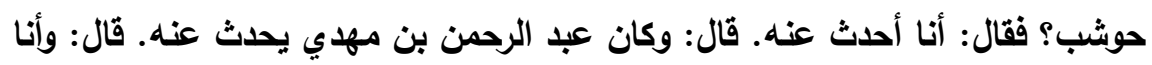

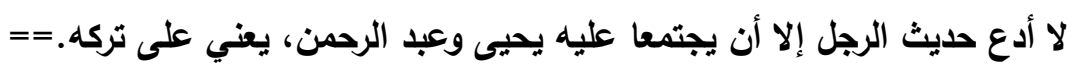


:

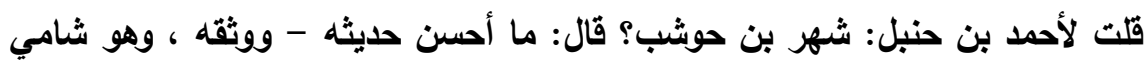
من أهل حمص. وأظنه قال: هو كندى روى عن أسماء بنت يزيل أحاديث حسانا أهـ .

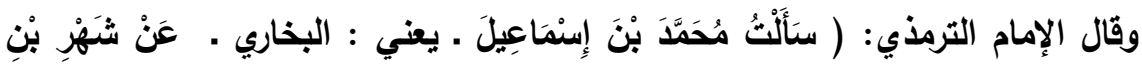

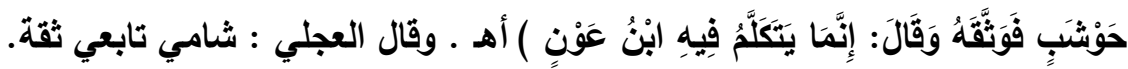

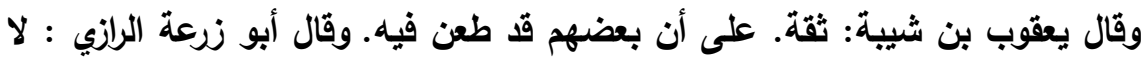

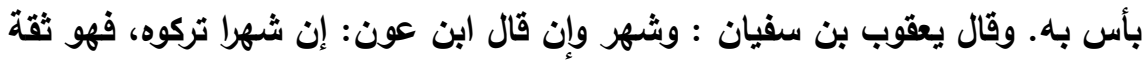

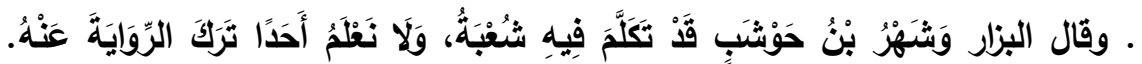

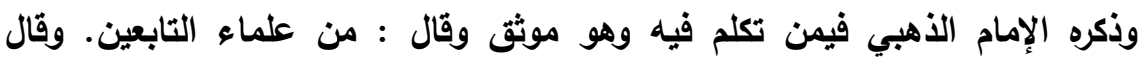

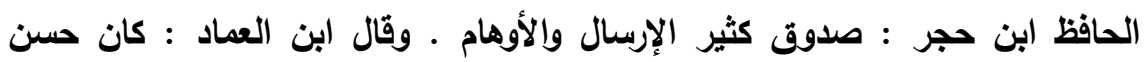

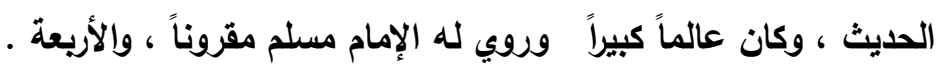

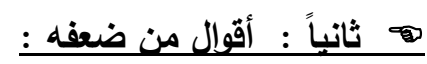

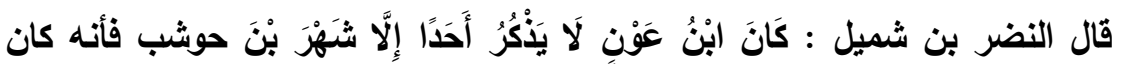

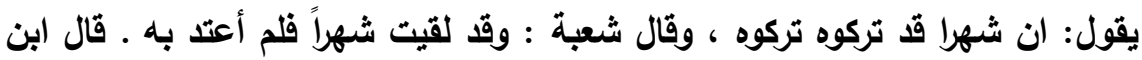
سعد : كان ضعيفاً في الحديث . وقال الجوزجاني : أحاديثه لا تثبه حديث الناس .

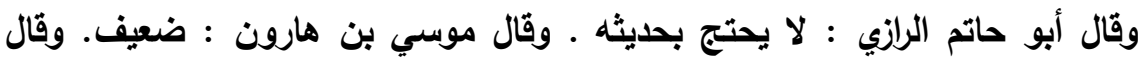
النسائي : ليس بالقوي. وذكره العقيلي في الضعفاء. وقال ابن حبان: كَانَ مِمَّن يَرْوِي

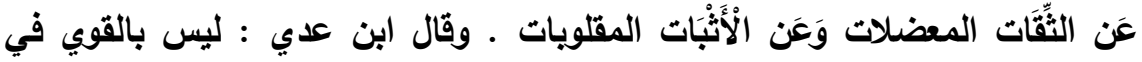

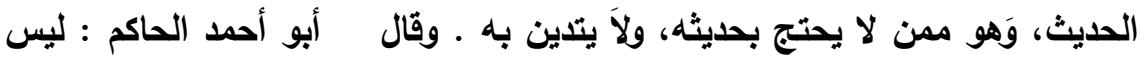

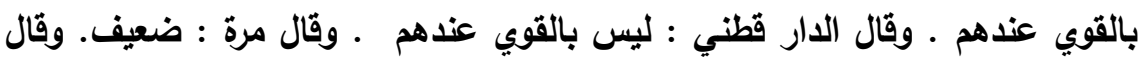

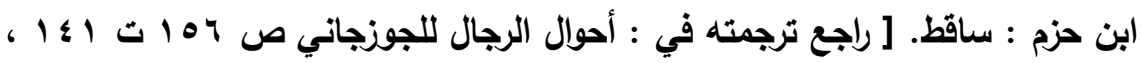

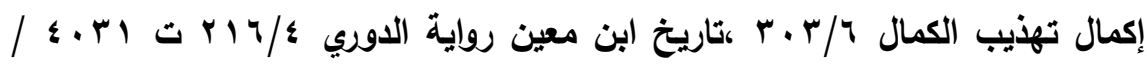

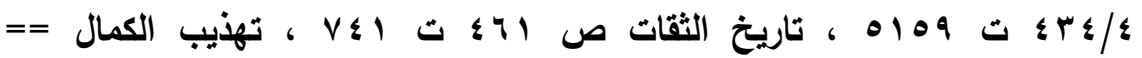




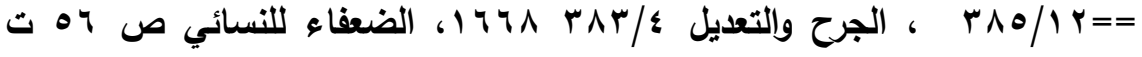

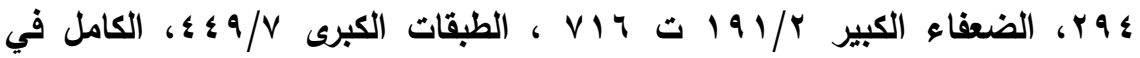

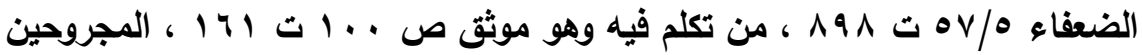

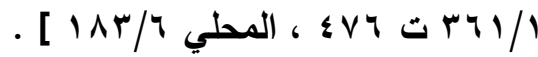

$$
\begin{aligned}
& \text { كما قلت : ولعل سبب تضعيفه : }
\end{aligned}
$$

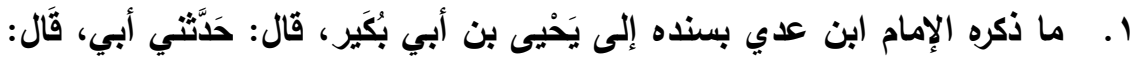

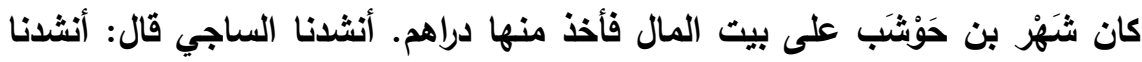
أحمد بن مُحَمد.

لقد باع شهر دينه بخريطة *** فمن يأمن القراء بعدك يا شهر) أهـ [الكامل في

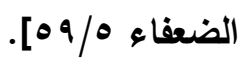

r. ما ذكره الإمام ابن عدي بسنده إلى عباد بن منصور قال : عجبت مع شَهْر بن

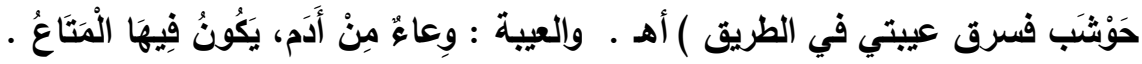

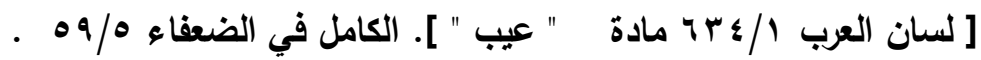

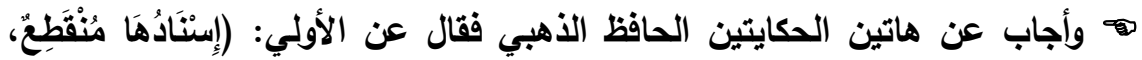

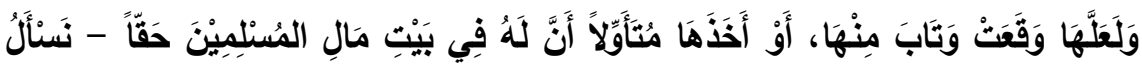

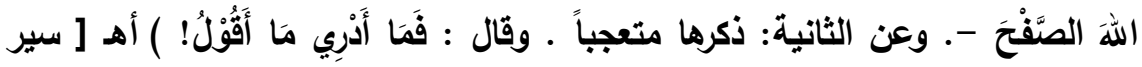

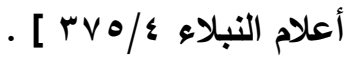
r. سماعه للآلات وهو ما ذكره الحافظ ابن عساكر فنكره بسنده إلى مسلم بن

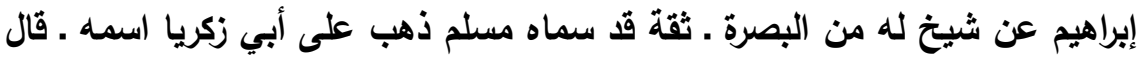

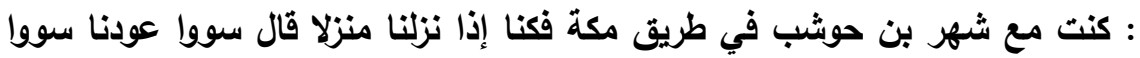

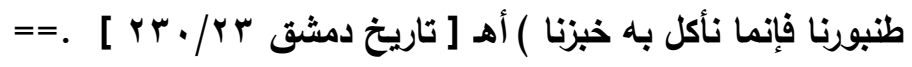


هأجاب عن تضعيفه الحافظ أبو الحسن بن القطان فقال : ( وَلْم أسمع لمضعفيه

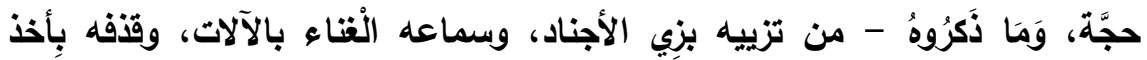

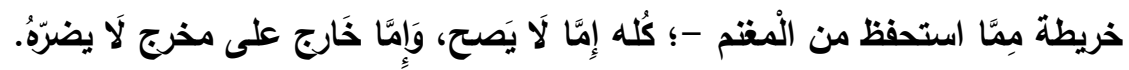

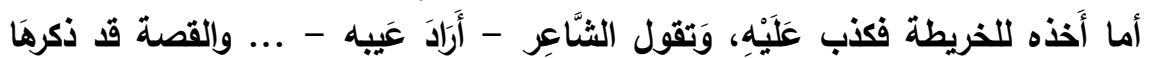
الطَّبريّي.

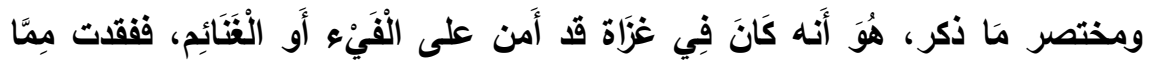

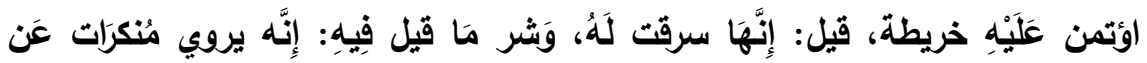

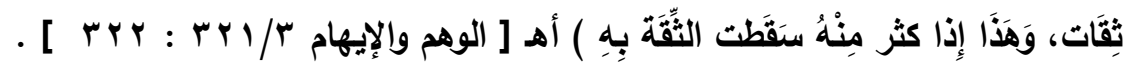
— وفاته : اختلف في سنة وفاته فقيل سنة ثمان وتسعين وقيل بعدها بسنة ، وقيل:

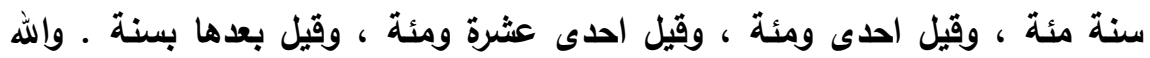

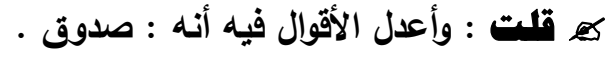
•ه المكم علي المديث : إسناده حسن لأجل شهر بن حوشب ، وإن كان في

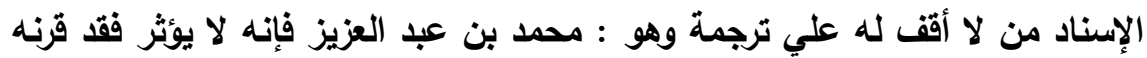

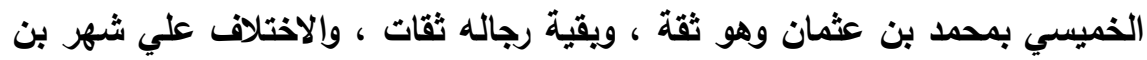

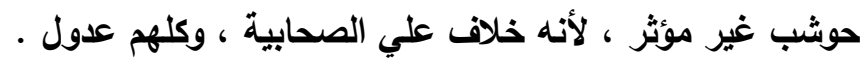

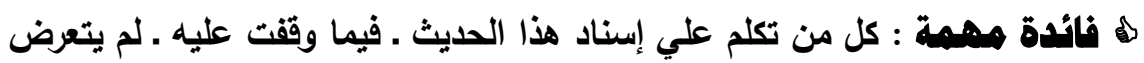
لمتابعة القطيعي لعبيدالله بن أبي زياد القاح ـ بفتح القاف وتثديد الدال المهملة ،

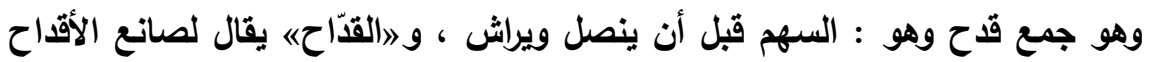

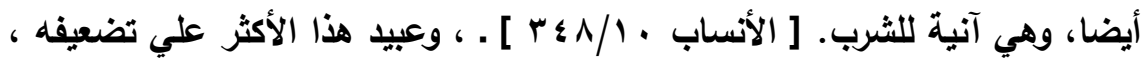

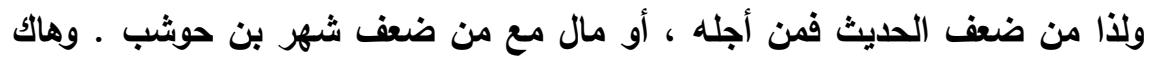

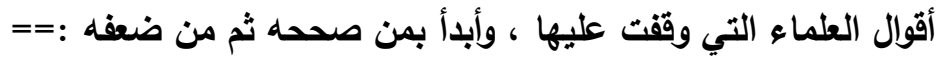


==قال الإمام الترمذي : حسن صحيح • وحسنه الثيخ / حسين سليم أسد في تحقيق

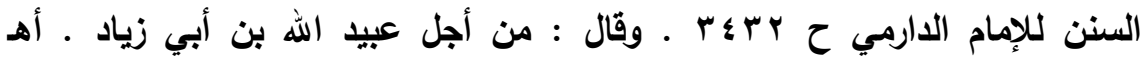

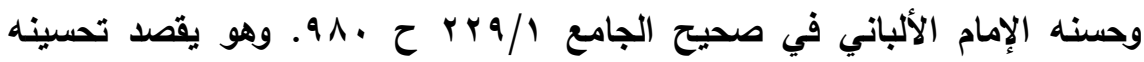

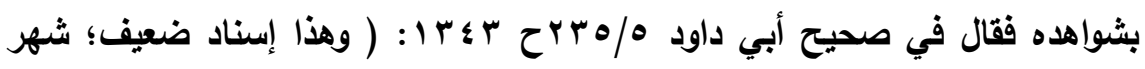

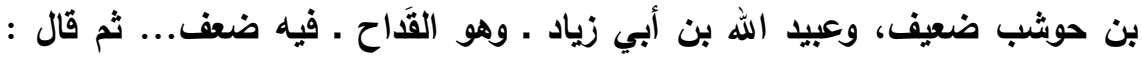

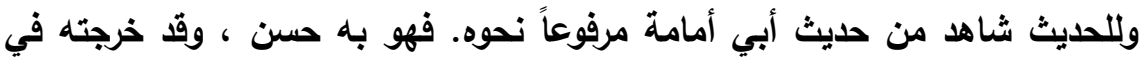

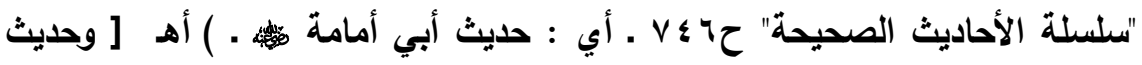
أبي أمامة هو: " اسم الله الأعظم في سور من القرآن ثلاث: في البقرة وآل عمران المانه

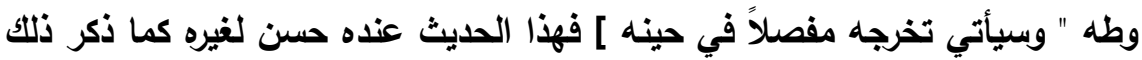

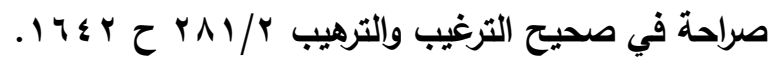
وضعفه الإمام عبد الغني المقدي فقال : ( سنده ضعيف ) أه [ الترغيب في الدعاء

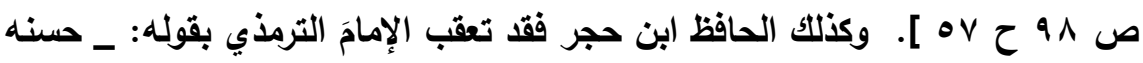

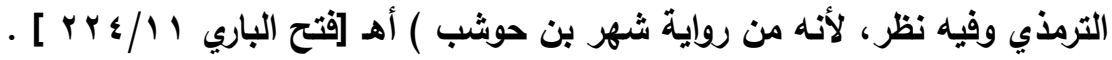

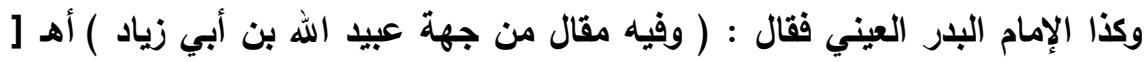

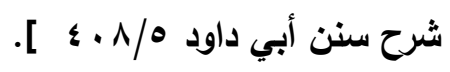

وقال الثيخ المناوي : (حسنه الترمذي مع أن فيه عبيد الله بن أبي زياد القداح فيه

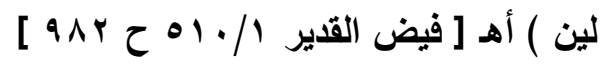

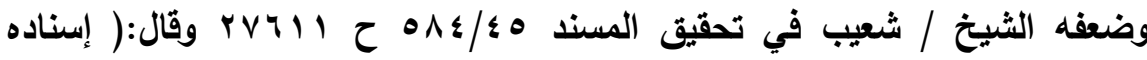
ضعيف لضعف عُبيد الله ابن أبي زياد ، وشهر بن حوشب ابن ) أهـ . كع قالت : فالإسناد من هذا الطريق ضعيف لأجل عبيد الله بن أبي زياد ، ويرتقي إلى الحسن لغيره بمتابعة أبي بكر أحمد بن جعفر القطيعي • والله أعلى وأعلم . 


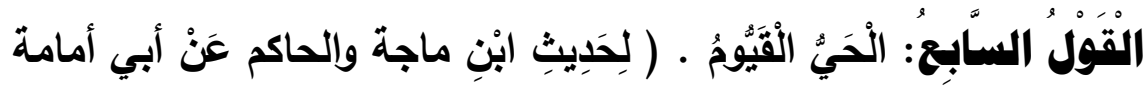

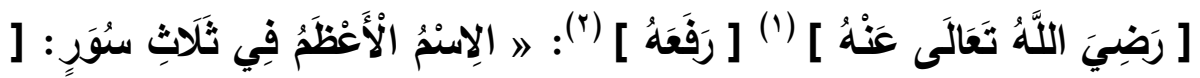

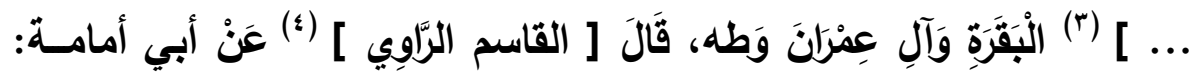

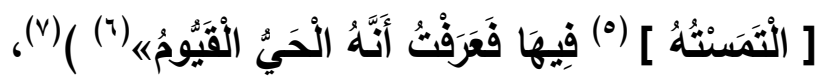

$$
\begin{aligned}
& \text { (') سقطت من "خ خ " }
\end{aligned}
$$

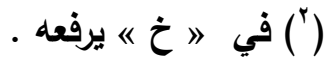

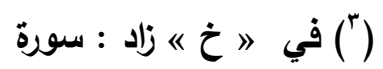

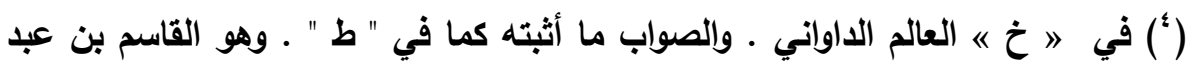

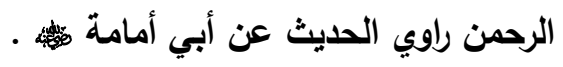

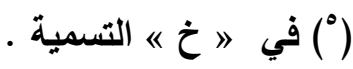

(") وعند الإمام الطحاوي في مشكل الآثار أن القائل هو : أبو حفص عمرو بن أبي سلمة

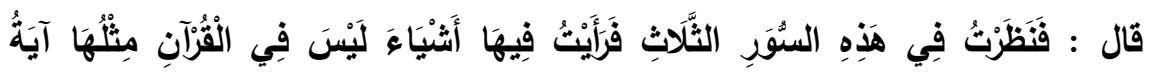

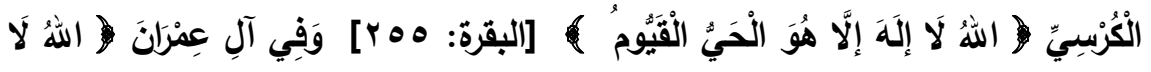

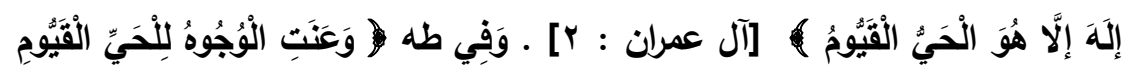
.

( ) رواه عمرو بن أبي سلمة أبو حفص التنيسي الامثقي ، واختلف عنه : فرواه خزيمة

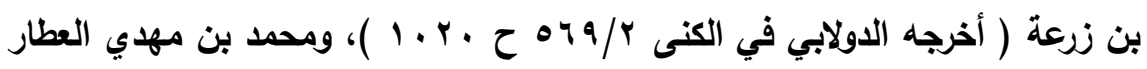

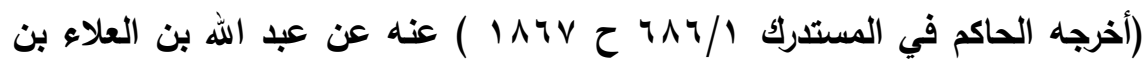

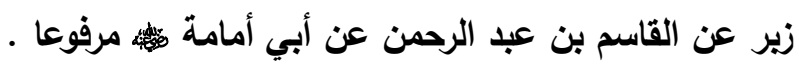

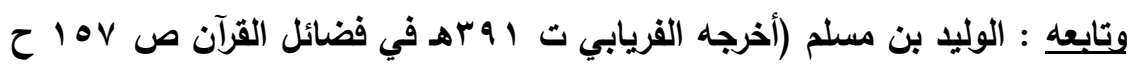

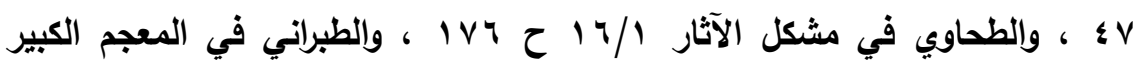

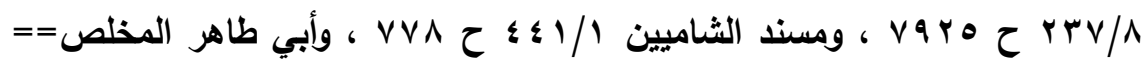




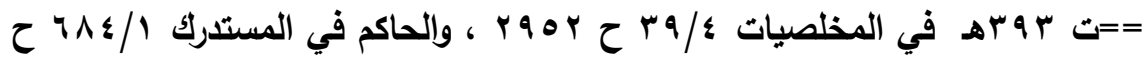

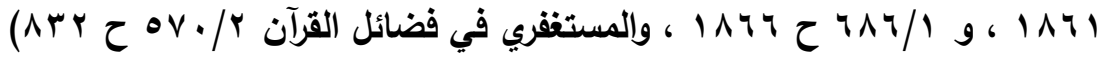
4< وخالفهم: عبد الرحمن بن إبراهيم دحيم الدمثقي : فرواه مرة عن عمرو بن

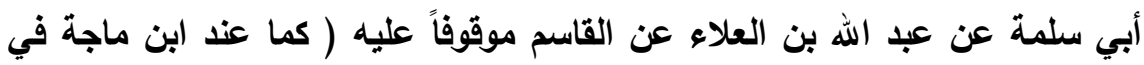

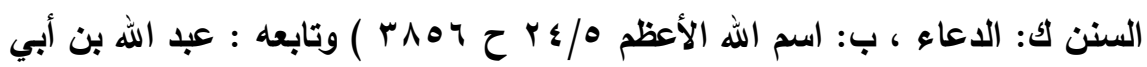

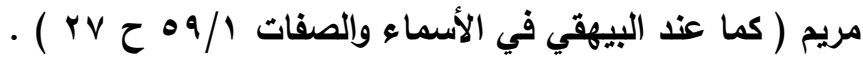

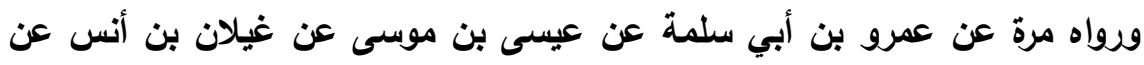

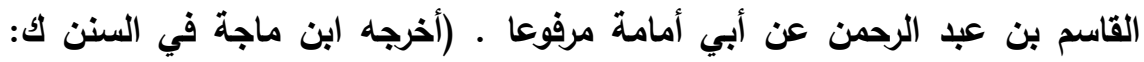

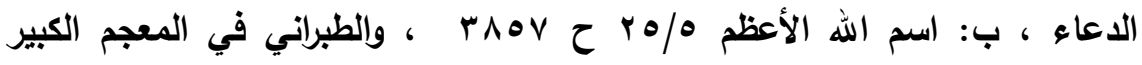

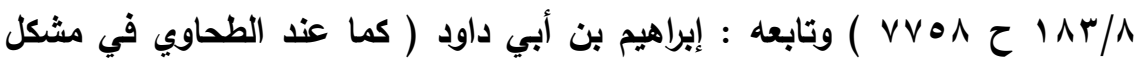

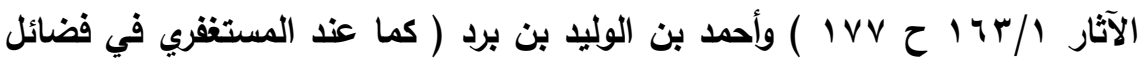

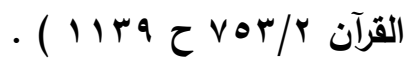
> وفيه علتان : الأولى : الاختلاف في رفعه وقطعه . الثانية : الاختلاف علي عمرو بن أبي سلمة في رفعه فرواه مرة عن عبد الله بن العلاء عن القاسم ، ومرة : عن عيسى بن موسى عن غيلان بن أنس عن القاسم .

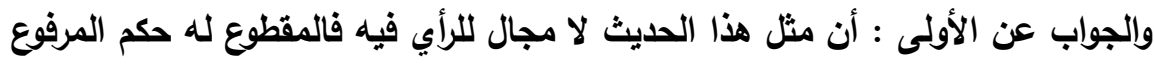

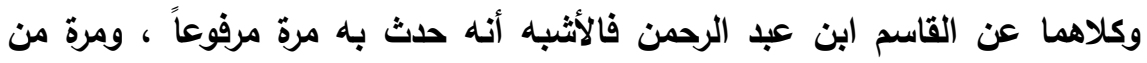
كلامه .

أما العلة الثانبة : الاختلاف علي عمرو بن أبي سلمة ، والراجح عندي أنه سمع

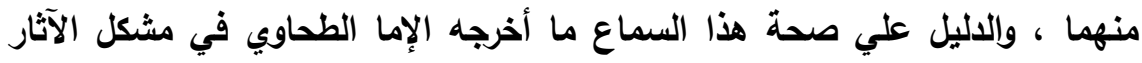

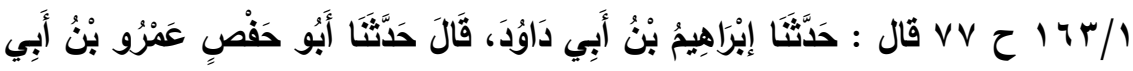

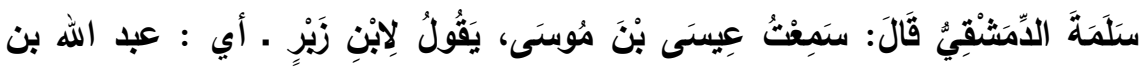

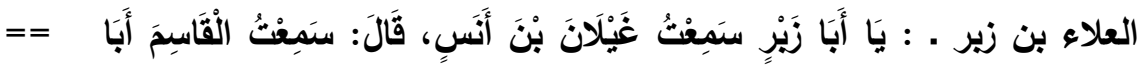




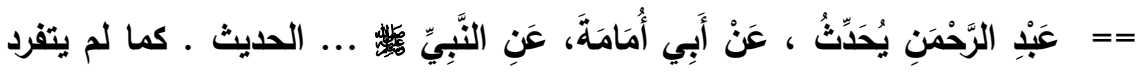

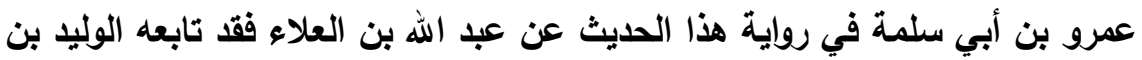
مسلم الدمشقي وقد صرح بالسماع من ابن العلاء ، وهما دمشقيان ـ وقال الإلمام

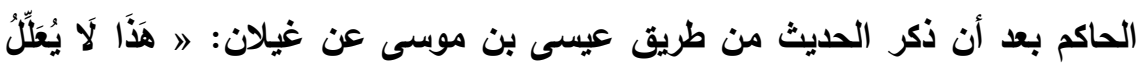

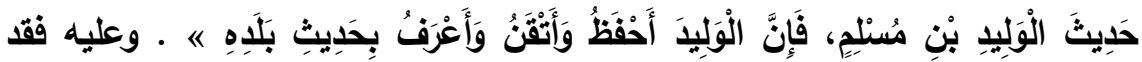

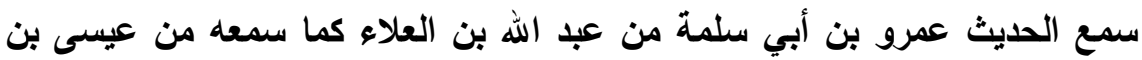
موسى • والله أعلم . مدئ

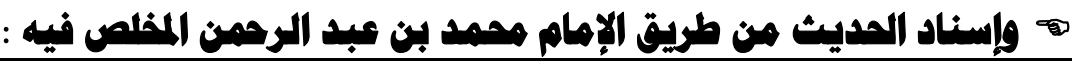

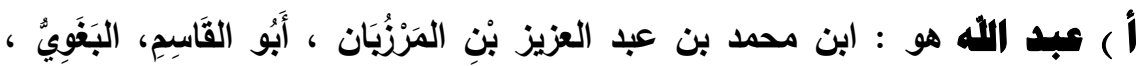

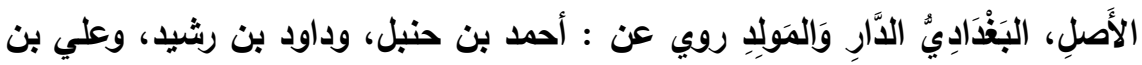

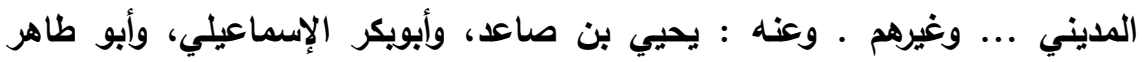

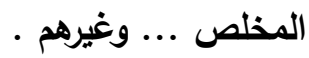
† مهلده : ولد يوم الإثنين أول يوم من شهر رمضان سنة أريع عشرة ومائتين

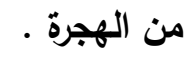

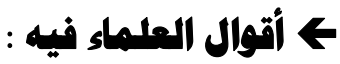

قال موسي بن هارون: ثقة صدوق، لو جاز لإنسان أن يقال له فوق الثقة لقيل له ،

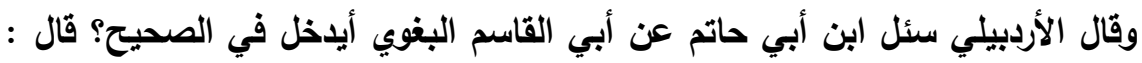

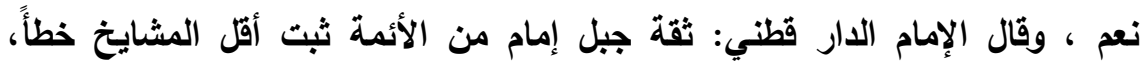

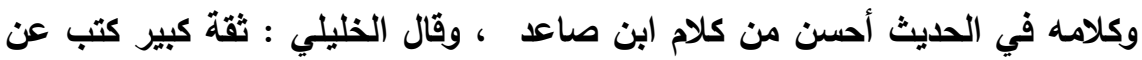

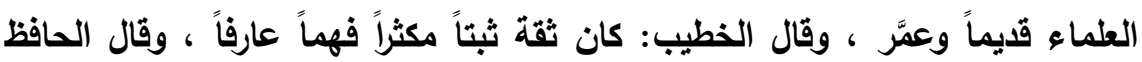

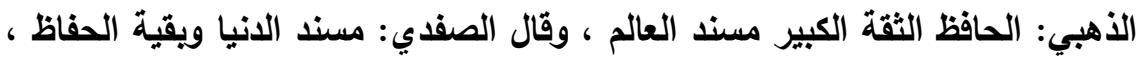
وذكره ابن قطلويغا في ثقاته ، وقال الحافظ السيوطي : الحافظ الكبير الثقة المسند

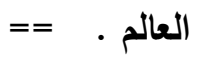


==وقال ابن عدي: الناس وأهل العلم مجمعين علي ضعفه وكانوا زاهدين من حضور

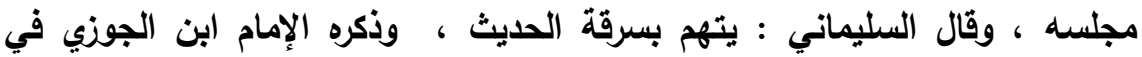

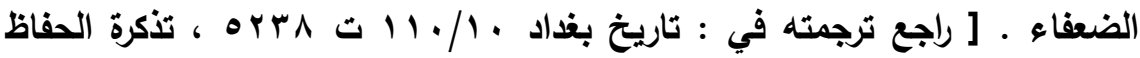

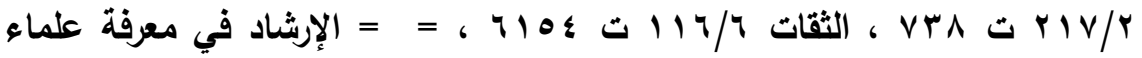

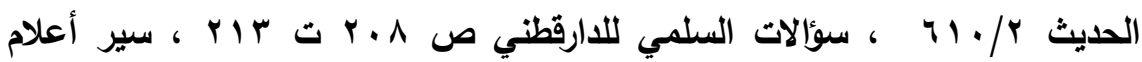

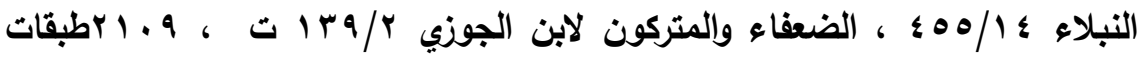

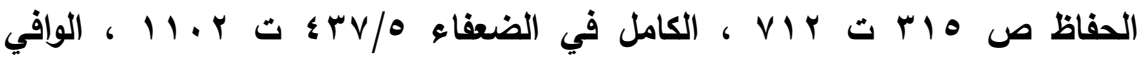

$$
\text { ب roq/IV بالوفيات }
$$

كهِ قلت :أما ذكر الإمام ابن عدي له في الضعفاء فقد رد عليه الحافظ الذهبي بقوله

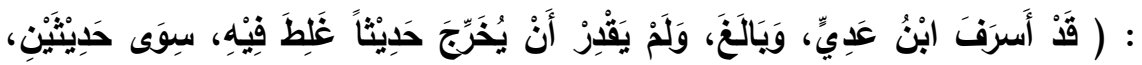

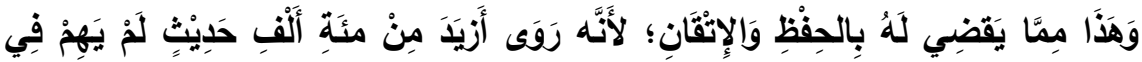

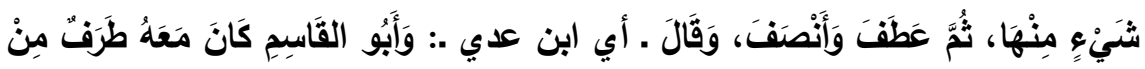

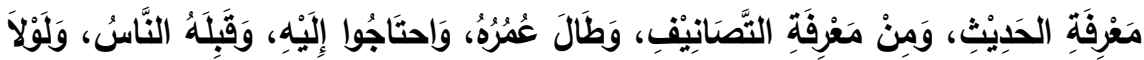

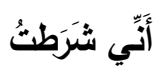

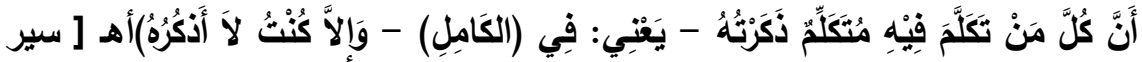

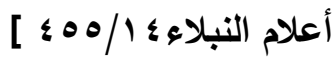
وذكره الإمام ابن الجوزي في الضعفاء لذكر الإمام ابن عدي لله، بل رد علي الإمام ابن

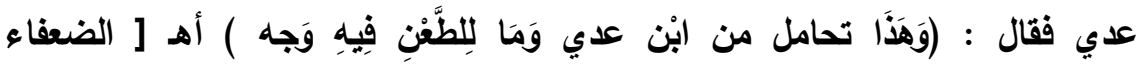

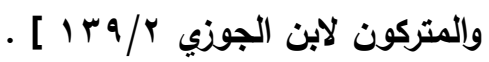

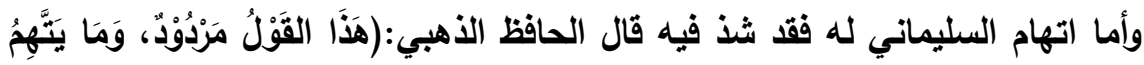

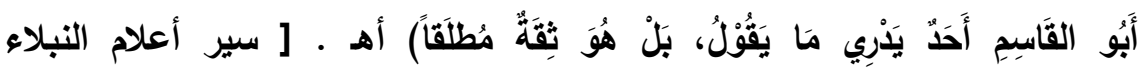

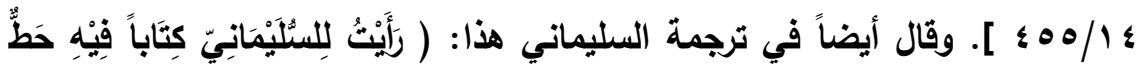

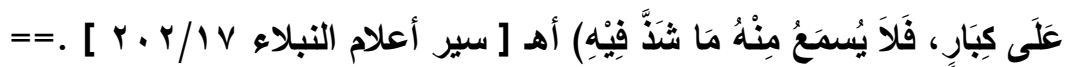


هـ وعليه : فهو ثقة حافظ مصنف .

ب) داوه هو : ابن رشيد ، أبو الفضل ، الهاشمى مولاهم ، الخوارزمى روي عن : إسماعيل ابن علية ، وحفص بن غياث، والوليد بن مسلم ، وغيرهم • وعنه : عبد الله بن أحمد بن حنبل ، وعبد الله البغوي ، وأبو حاتم الرازي ، وغيرهم . ك أقوال المالماء فيه : وثقه ابن سعد ، وابن معين ، وذكره ابن حبان في الثقات ، وقال الدارقطني : ثقة نبيل ، وقال الحافظ الذهبي: الحافظ الثقة ، وقال الحافظ ابن حجر: ثقة وروي لله الجماعة عدا الترمذي ، وقال أبو حاتم الرازي : صدوق •

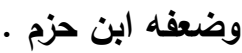

ب وفاته : توفي سنة تسع وثلاثين ومئتين • [ راجع ترجمته في : تاريخ بغداد

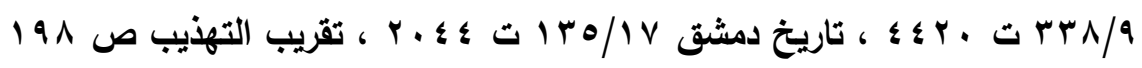

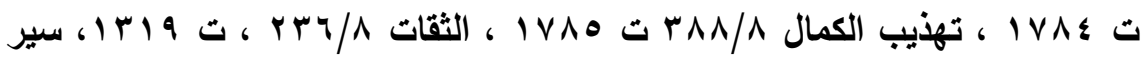

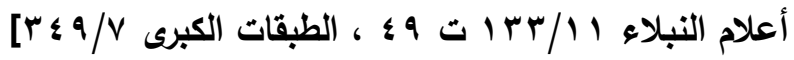
أما تضعيف ابن حزم لله فقد رده الحافظ ابن حجر بقوله : (وهم ابن حزم ، فقال إثر حديث أخرجه من روايته فى كتاب الحدود من " الإيصال " : داود بن رشيد ضعيف )

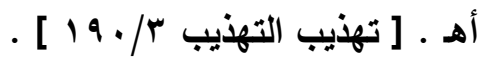

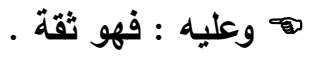

ت ) الوليد بن مسلم : ثقة مدلس ـ ـ ذكره الحافظ ابن حجر في المرتبة الرابعة من طبقات المدلسين ـوهي: من اتفق على أنه لا يحتج بشئ من حديثهم الا بما صرحوا

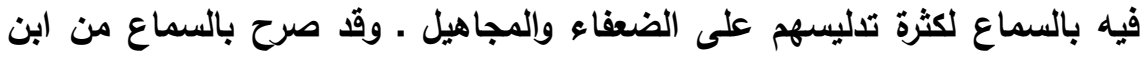

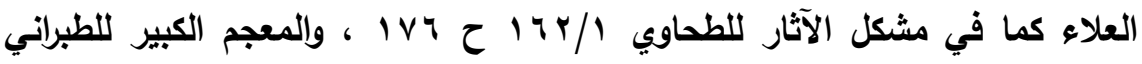

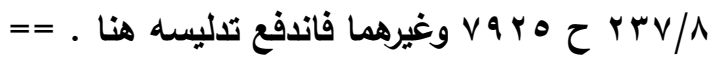


ت ) القاسم هو : ابن عبد الرحمن ، أبو عبد الرحمن ، الثامي ، الدمثقي ، روى

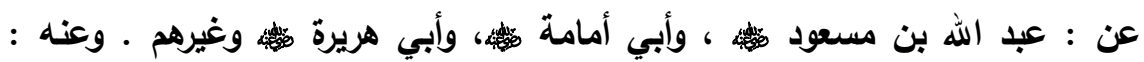
حفص بن غيلان ، وعبد الله بن العلاء ، وغيلان ابن أنس ، وغيرهم .

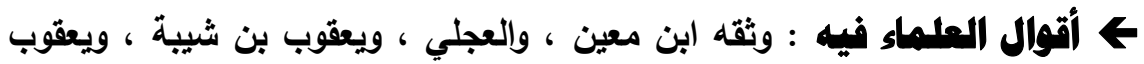

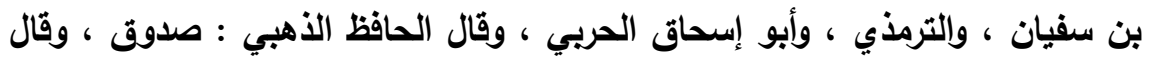

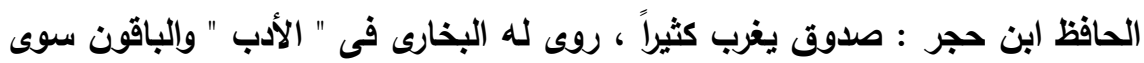
مسلم . مصنم وضعفه شعبة ، وأحمد ، وقال الغلابي : منكر الحديث ، وقال ابن حبان : يروي عن

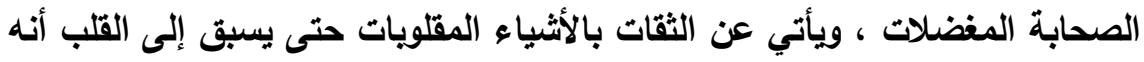

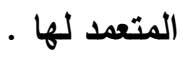

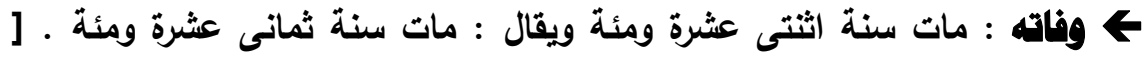

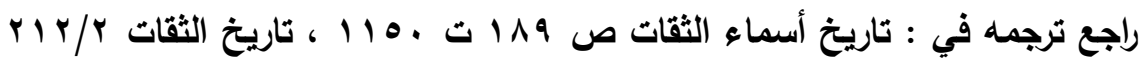

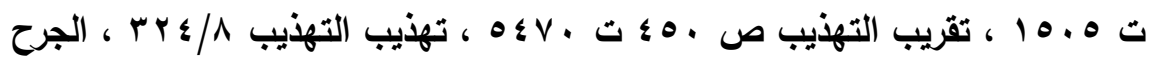

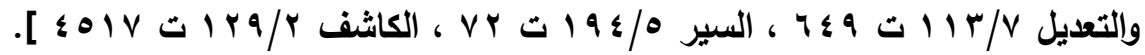
أما قول الغلابي منكر الحديث ، فلعله يقصد بالنكارة : التفرد وهو ما أشار إليه الحافظ ابن حجر بقوله : يغرب كثيراً ، وتضعيف من ضعفه إنما أوتي من قبل رواية الضعفاء

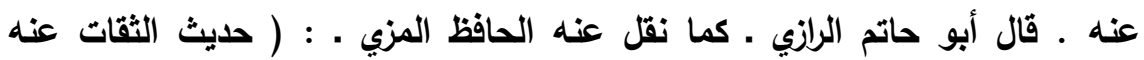

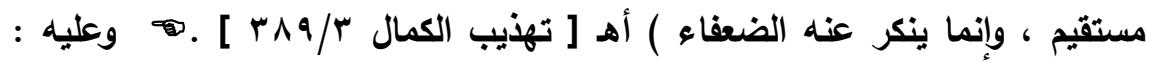
فهو صدوق يغرب كثيرًا . هم المكم علي المديث : إسناده حسن لأجل القاسم بن عبد الرحمن ، ومدار

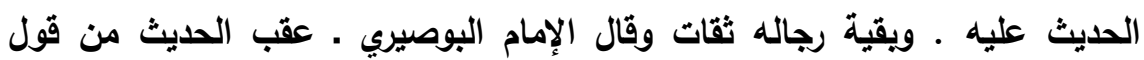

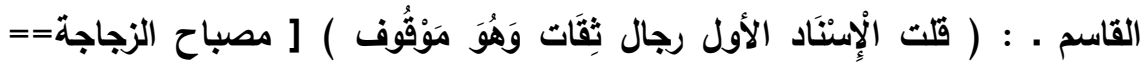




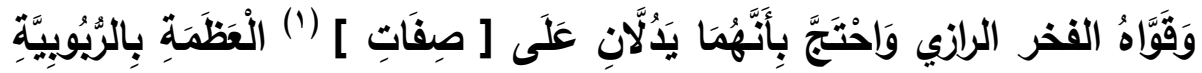

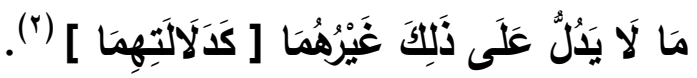

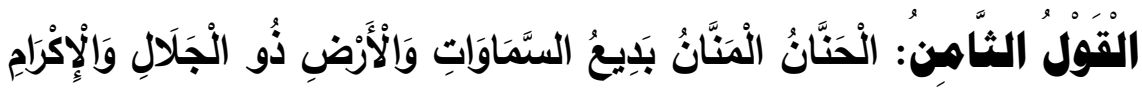

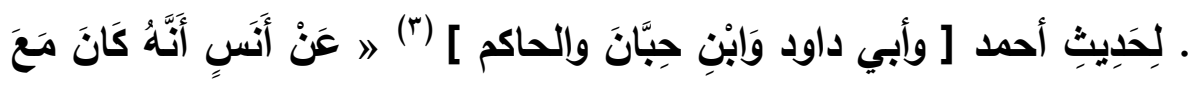
رَسُولِل اللَّهِ

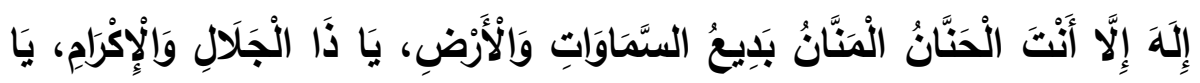

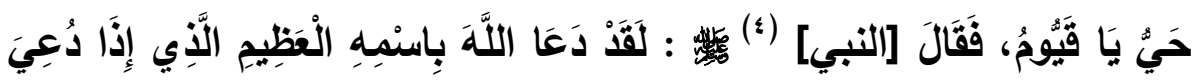

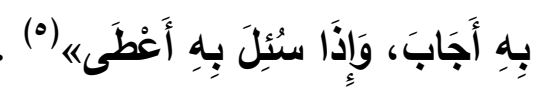

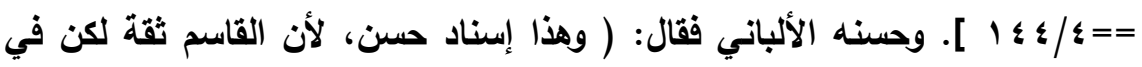

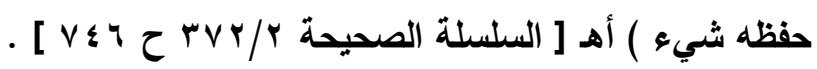

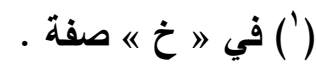

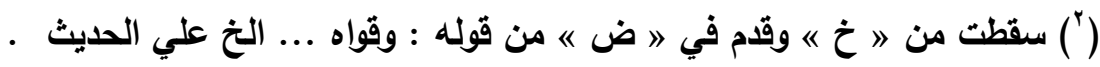

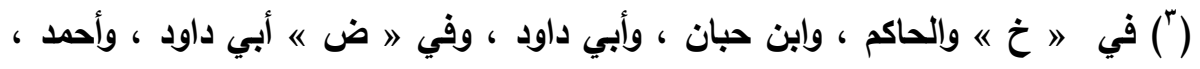

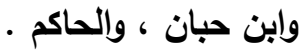

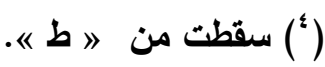

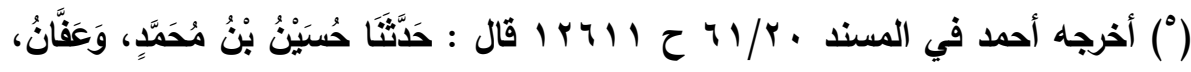

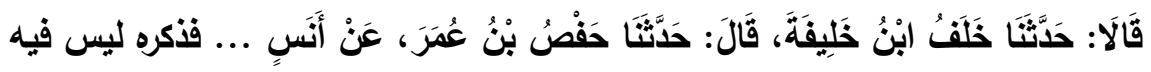

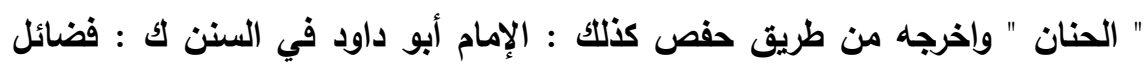

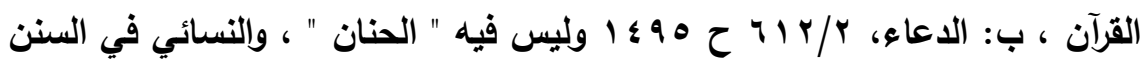

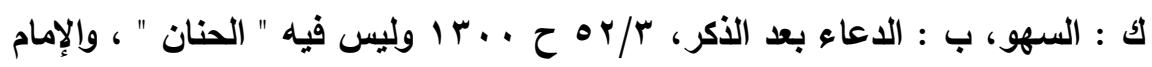

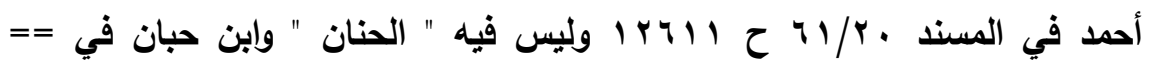

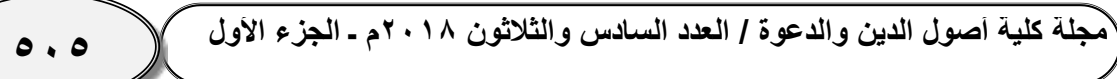




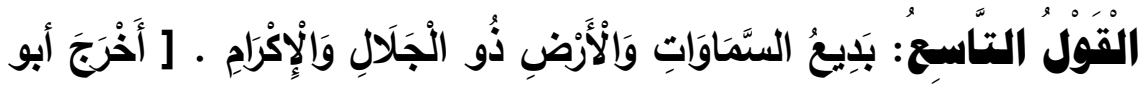

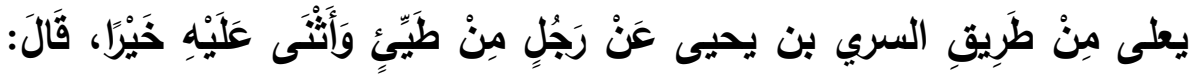

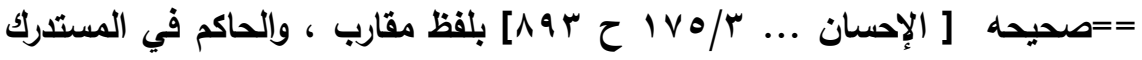

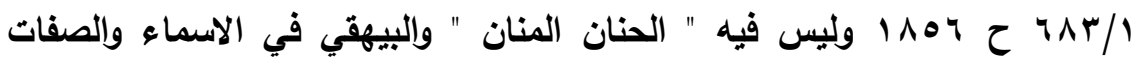
إl/1/

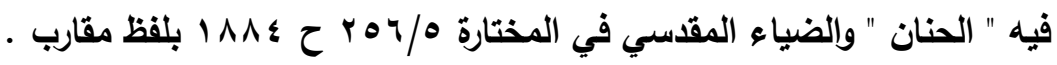
وتابع حفص : أنس بن سيرين ، وأبان بن أبي عياش ، وإبراهيم بن عبيد. فأخرجه

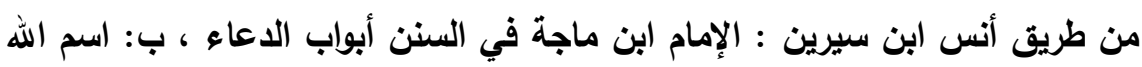

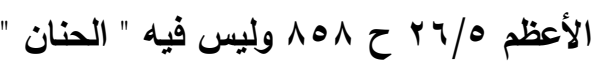
وأخرجه من طريق أبان بن أبي عياش :الحارث في المسند إبغية الباحث عن زوائد

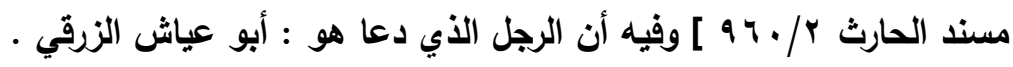

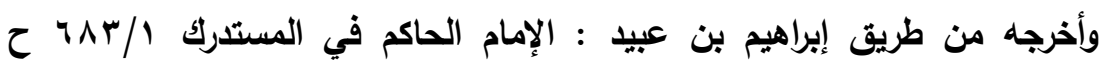

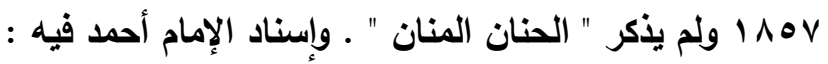
خلف بن خليفة هو : ابن صاعد ، أبو أحمد الواسطي : صدوق اختلط بأخرة كما

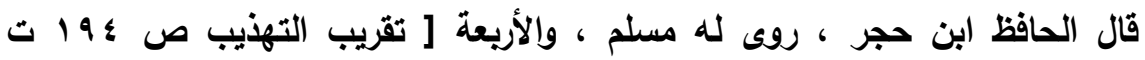

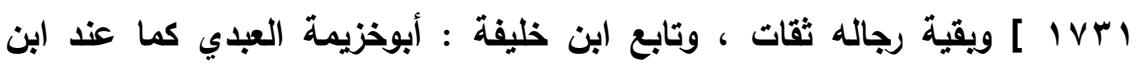
ماجة، وسعيد بن عامر كما عند الحارث، وعياض بن عبد الله الفهري كما عند الحاكم

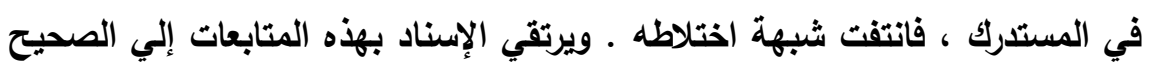




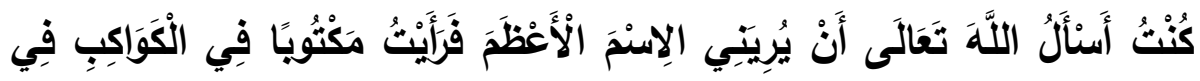

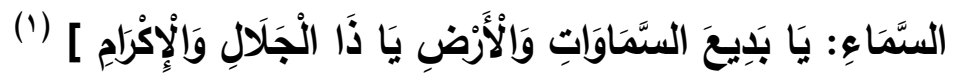

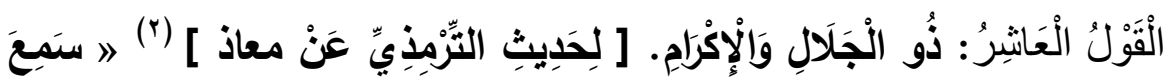

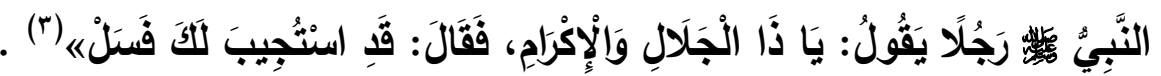

(') سقطت من " خ " ، وذكره في " ض " ض ضمن القول السابق ، ولم يفرده ـ أخرجه

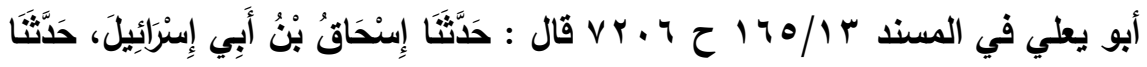

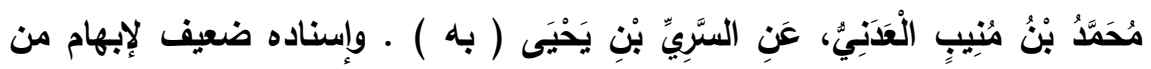

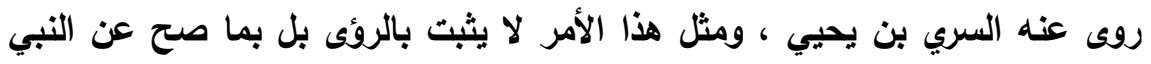
.

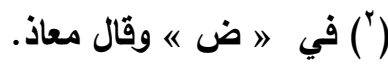

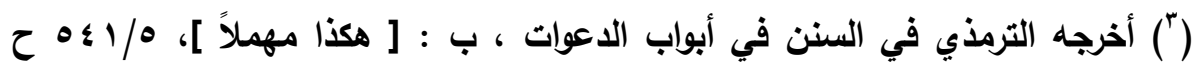

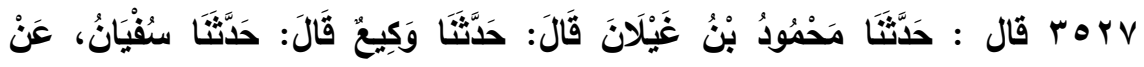

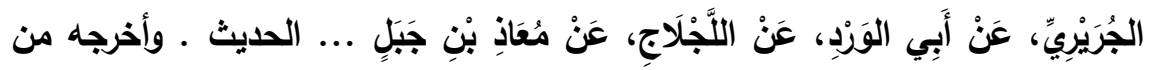

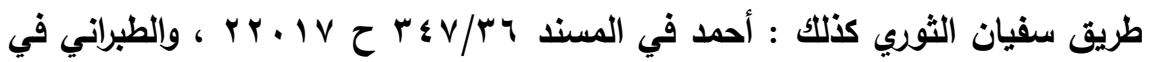

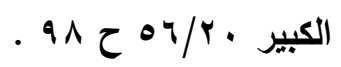

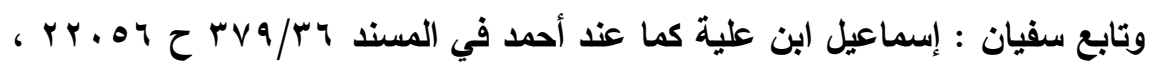

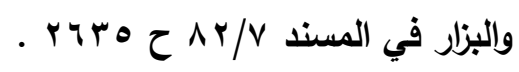

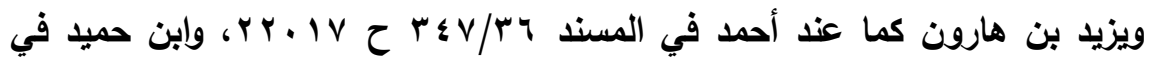

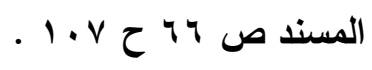

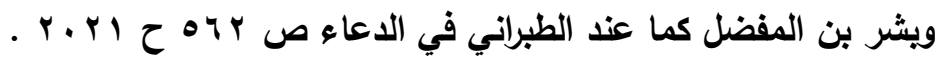

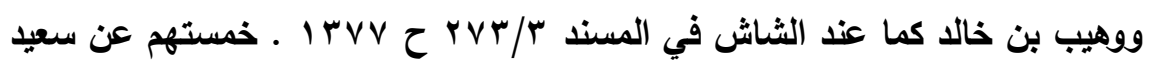

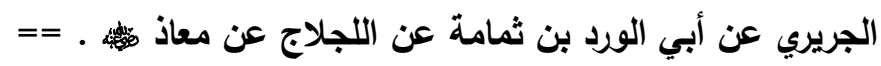




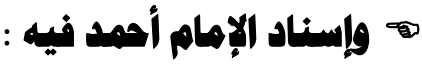

أ ) أبو الورد هو : ابن ثمامة بن حزن ، القثيري ـ قال ابن سعد : كان معروفاً قليل

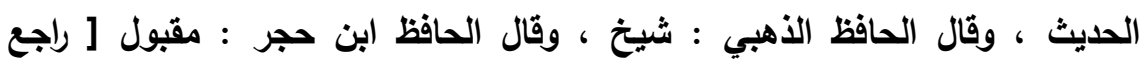

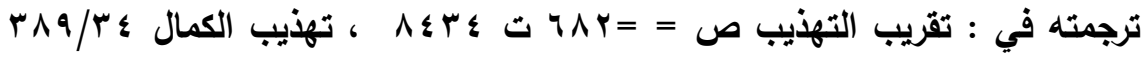

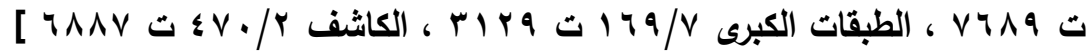
كع قلت : روى عنه : سعيد الجريري ، وشداد بن سعيد ، وقال الإمام أحمد في العلل .

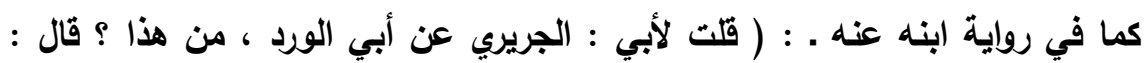

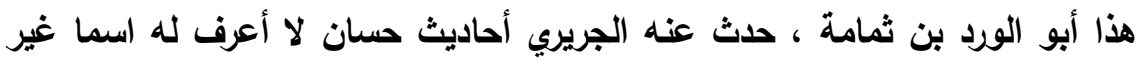

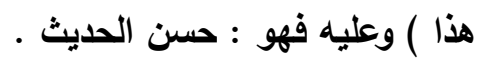
ب) الجريري هو : سعيد بن إياس ، أبو مسعود ، البصرى . وثثقه ابن سعد وقال

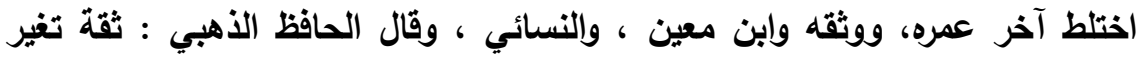

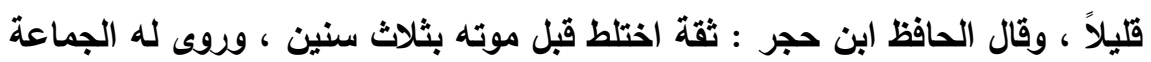

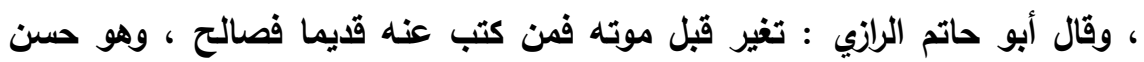

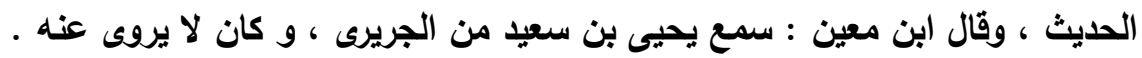

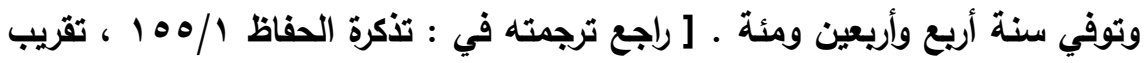

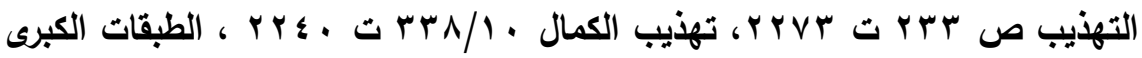

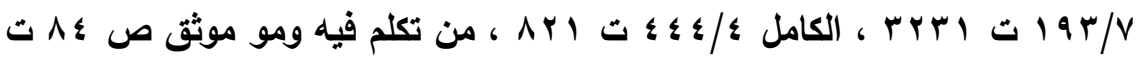

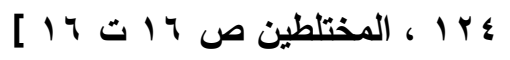

كع قلت: هو ثقة اختلط آخر عمره ، وضعفه القطان لتغيره آخر عمره كما قال الحافظ

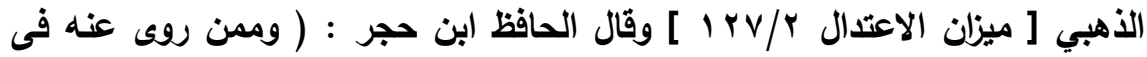
الاختلاط : يزيل بن هارون ، وابن المبارك ، وابن أبى عدى ، و كل ما ما روى عنه مثله مثل

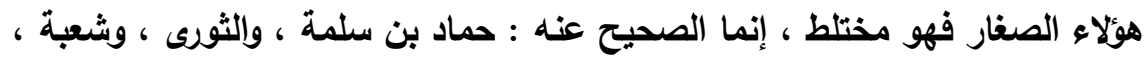

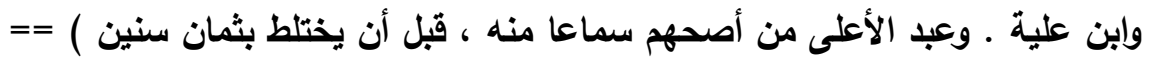




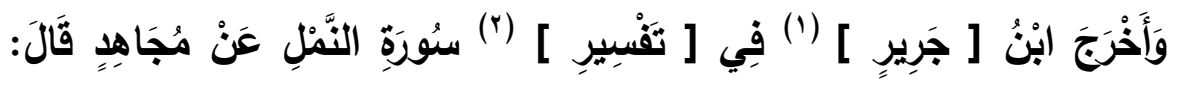

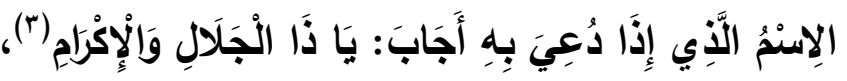

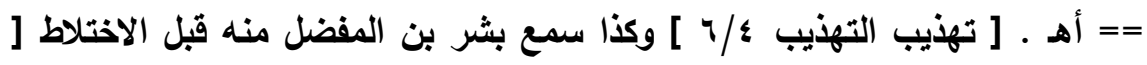

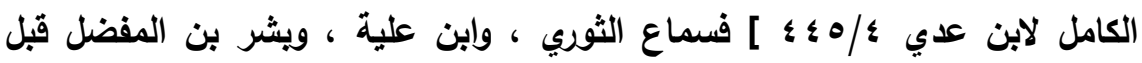

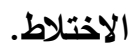
هم وعليه فالإسناد حسن ، لأجل أبي الورد ، ومدار الحديث عليه ، ويقية رجاله

$$
\begin{aligned}
& \text { ثُقات . }
\end{aligned}
$$

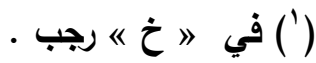

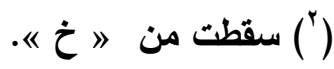

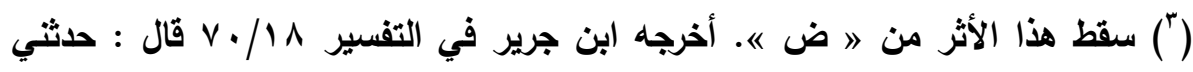

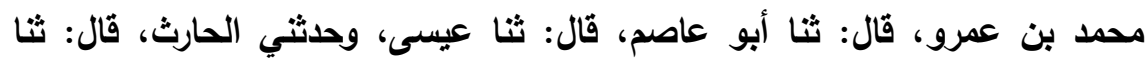

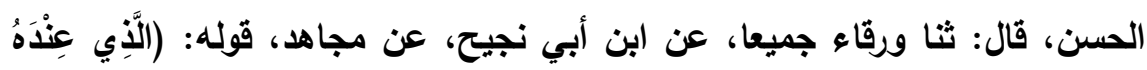

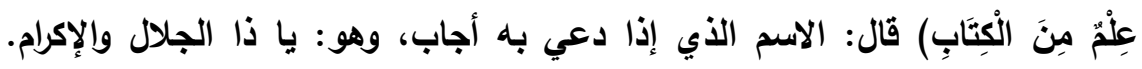

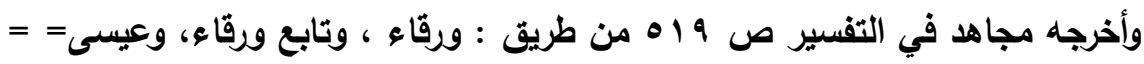
ابن ميمون : شبل بن عباد المكي أخرجه هبة الله اللاككائي في كرامات الأولياء

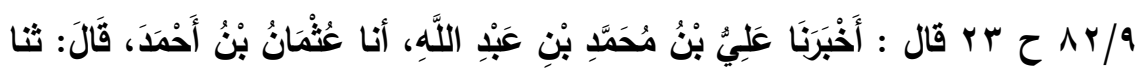

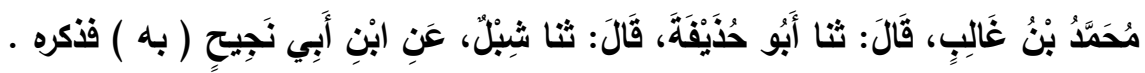

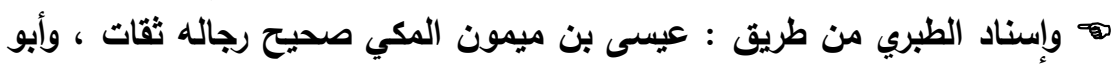
عاصم هو الضحاك بن مخلا، ومحمد بن عمرو هو : ابن العباس الباهلي . 0.9 جلمة كلية اصول الدين والدعوة / العدد السادس والثلاثتون ^1 ـ ب ـ ـ الجزء الاول 


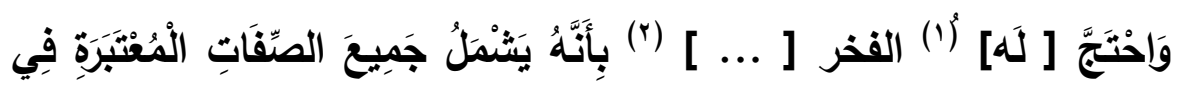

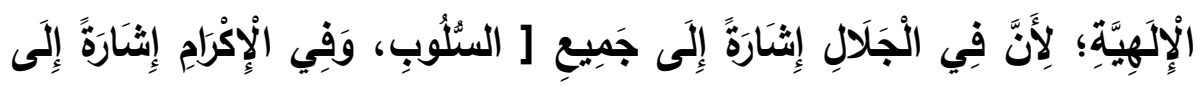

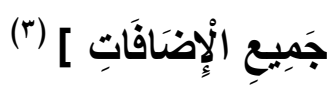

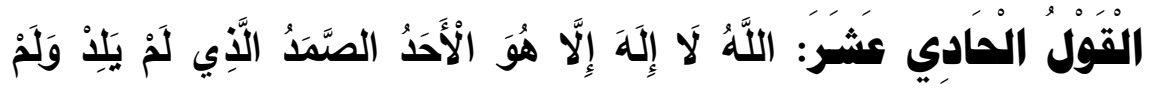

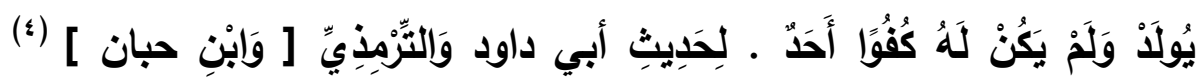

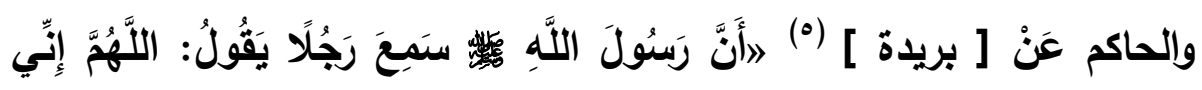

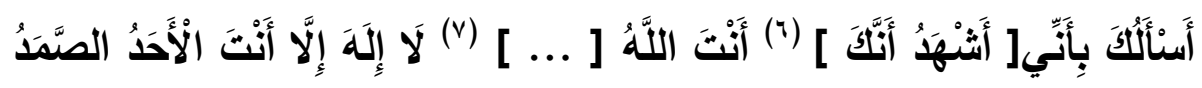

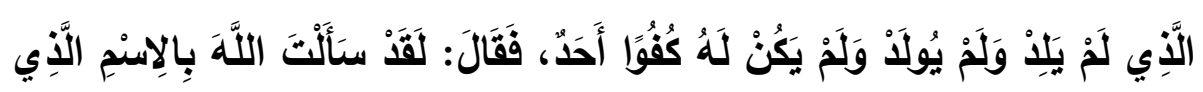

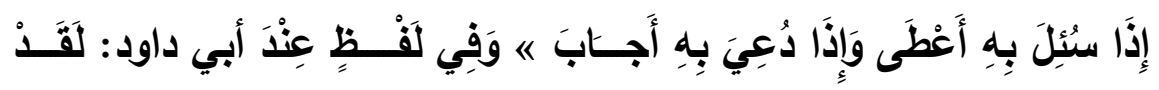

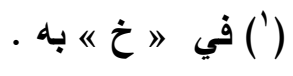

.

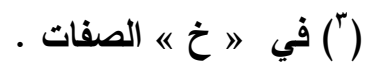

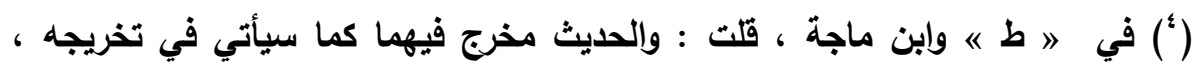
وفي" ض ش " والترمذي والحاكم .

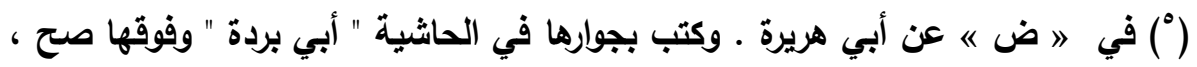

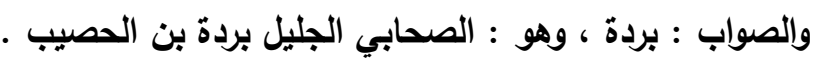

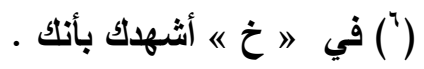

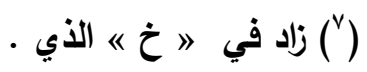




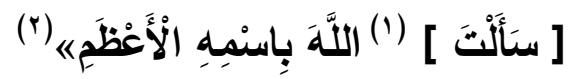

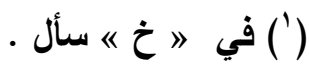

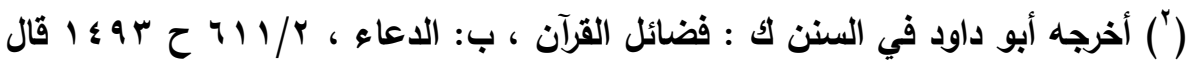

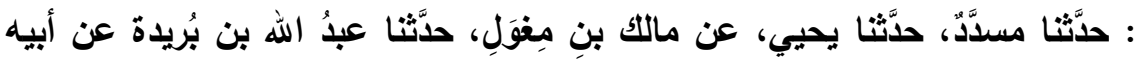

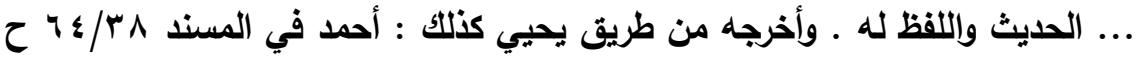

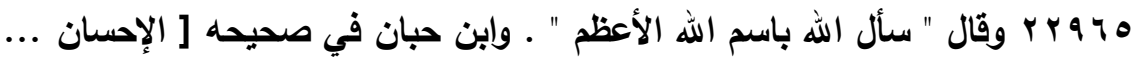

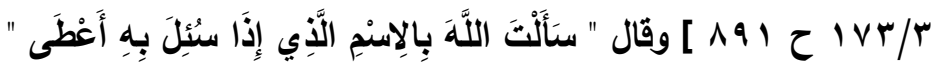

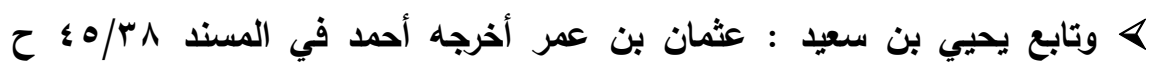

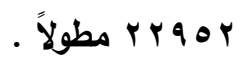

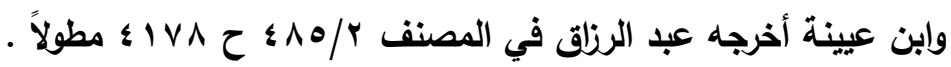

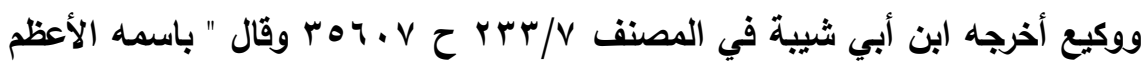

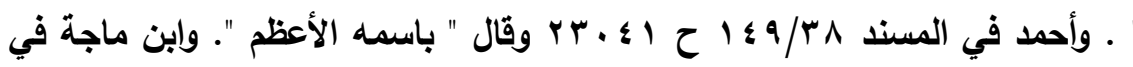

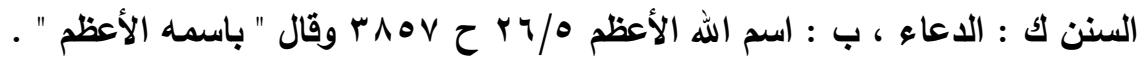

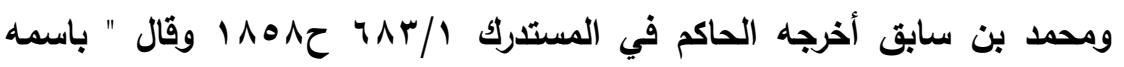

وزيد بن الحباب أخرجه أبي داود في السنن ك : فضائل القرآن ، ب: الدعاء ، الداء

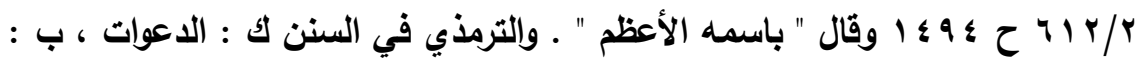

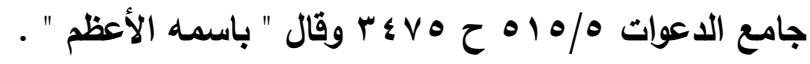

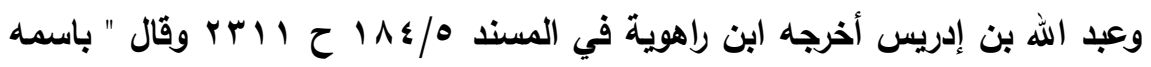

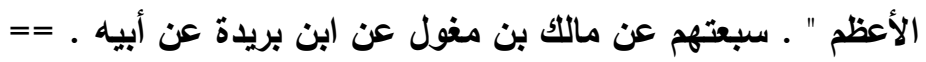




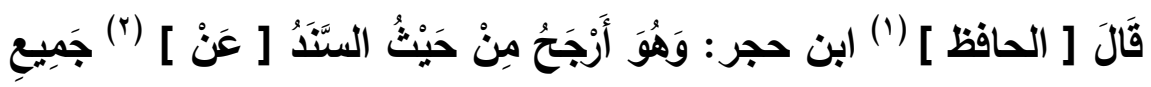

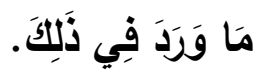

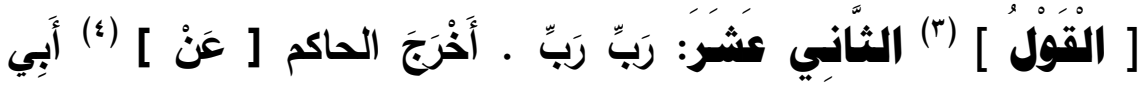

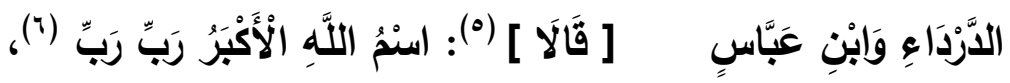

\&> وخالفهم : شريك بن عبد الله فرواه عن أبي إسحاق السبيعي عن ابن بريدة

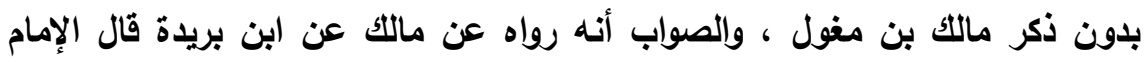

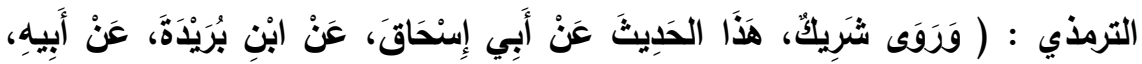

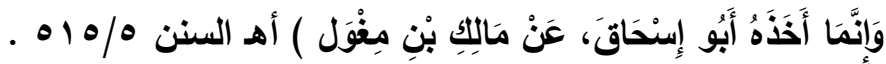
كم المكم علي المديث : أخرجه الإمام أحمد عن : عثمان بن عمر ـ هو ابن فارس

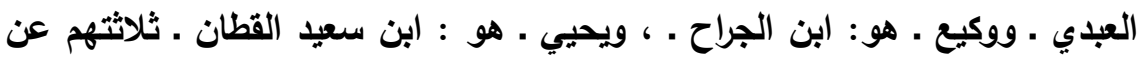

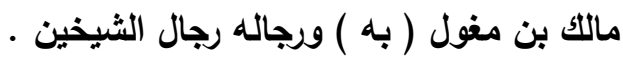

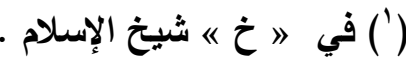

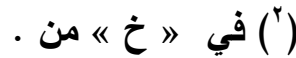

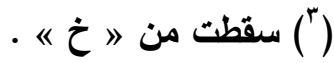

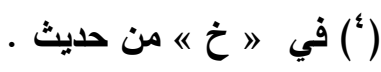

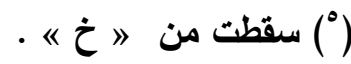

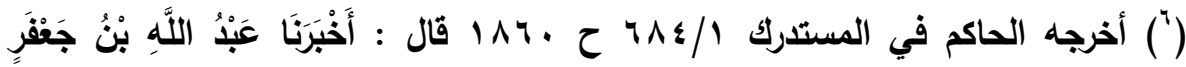

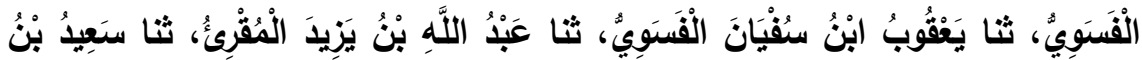

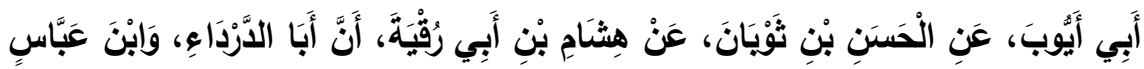

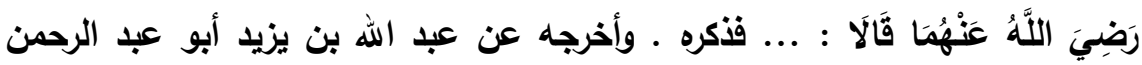

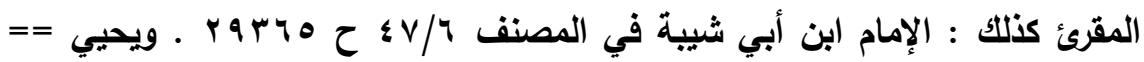




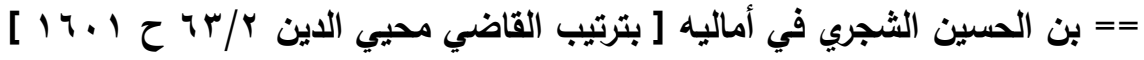

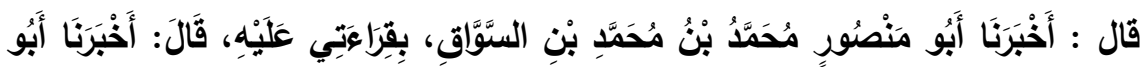

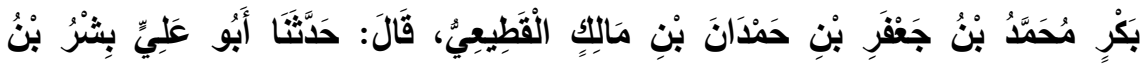

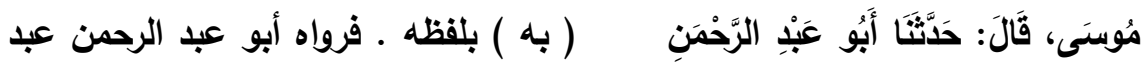

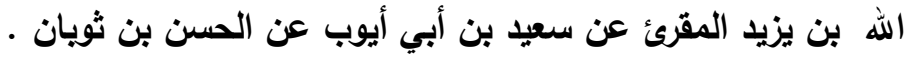
\&> وخالفه: عبد الله بن وهب فقال: عن سعيد بن أبي أيوب والحسن بن ثويان عن

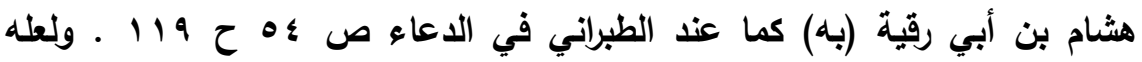
تصحيف في المطبوع إذ أن ابن وهب لم يرو عن الحسن بن ثنام أويان مباشرة وإنما يرو

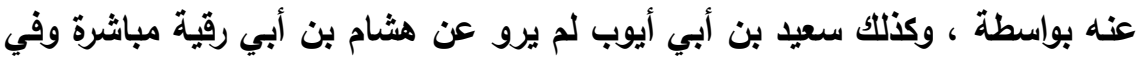

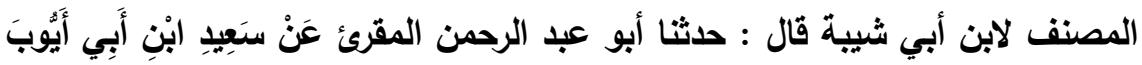

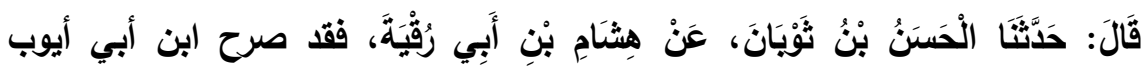

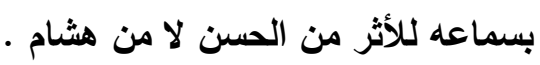
مه المكم علي الأثم : أخرجه ابن أبي شيبة بإسناد حسن : فيه : الحسن : الحسن بن ثويان

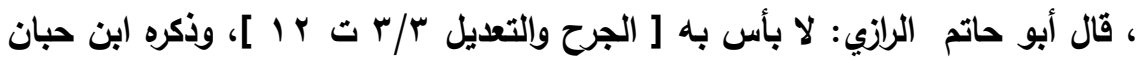

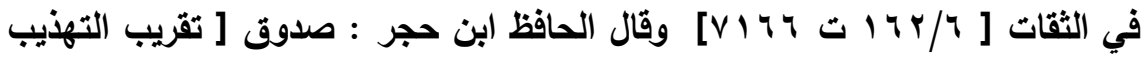

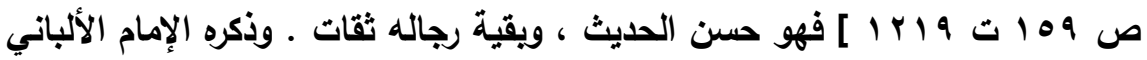

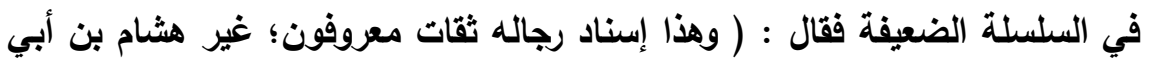
رقية: فذكره البخاري وابن أبي حاتم في كتابيهما، ولم يذكرا فيه جرحاً ولا تعديلاً؛ لكن

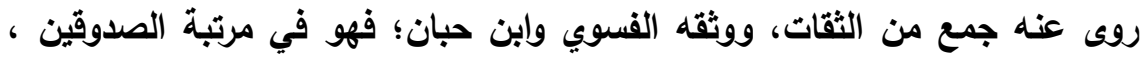

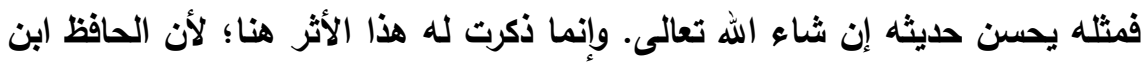

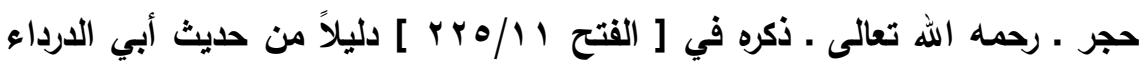

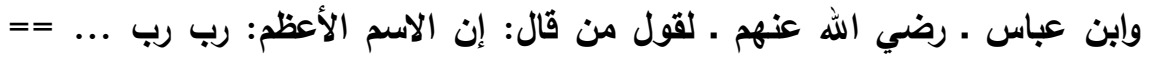




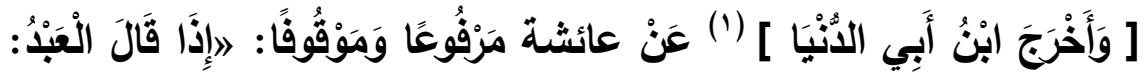

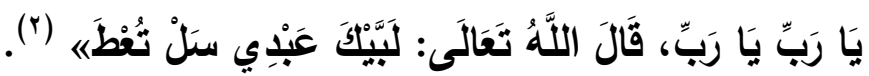

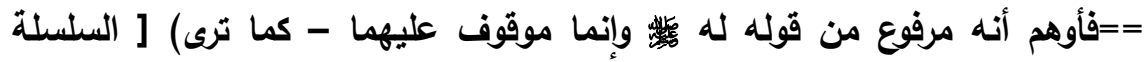

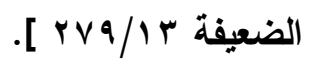$$
\text { كer }
$$

أ ) ليس كلام الحافظ ابن حجر بمسوغ لذكر الأثر في الضعيف ، خاصة مع تصدير

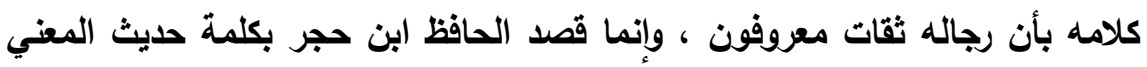

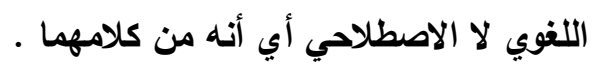

ب) أما كلامه عن : هشام بن أبي رقية، وتحسين حليثه ، إنما هو ثقة إن شاء الله ، نعم

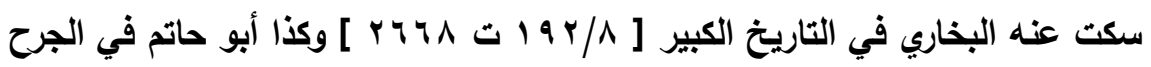

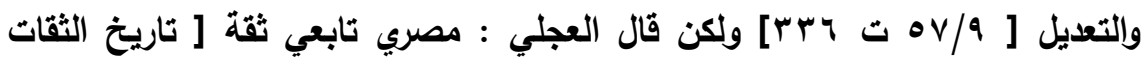

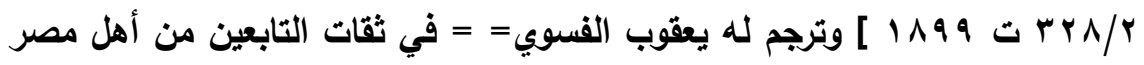

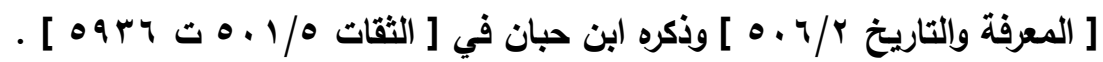

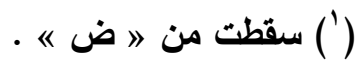

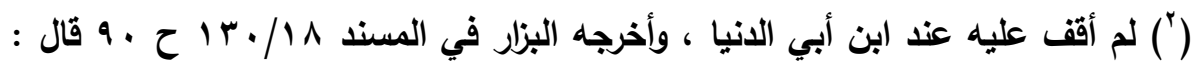

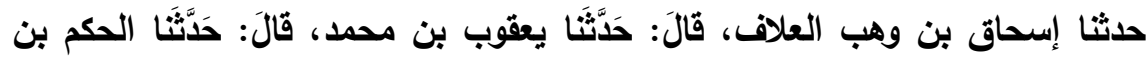

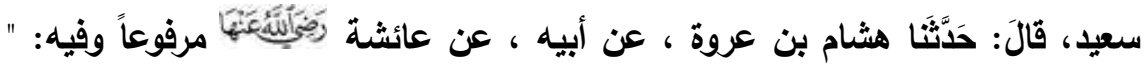

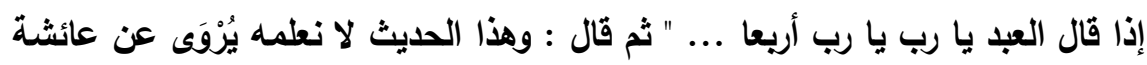

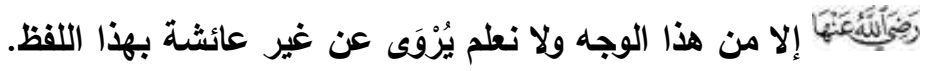
كم المكم علب المديث : ضعيف جداً فيه : الحكم بن سعيد الأموي : منكر الحديث

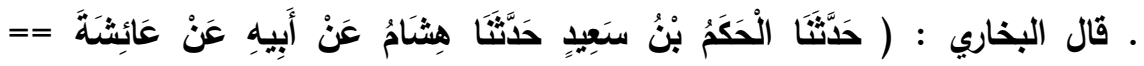




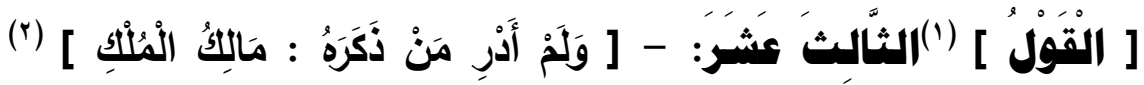

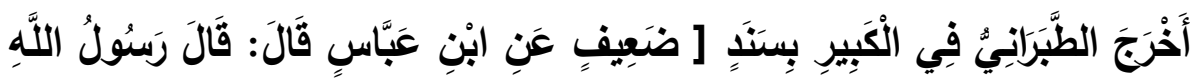

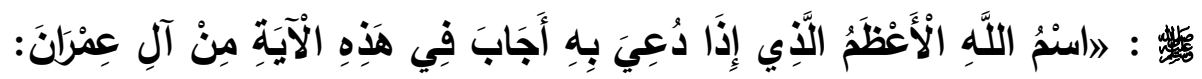

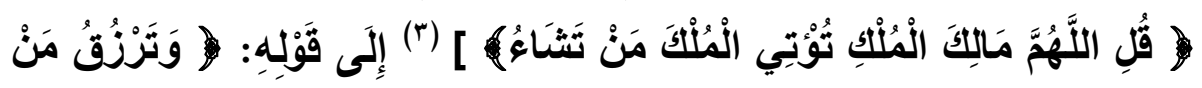

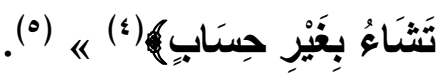

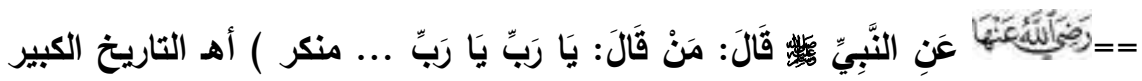

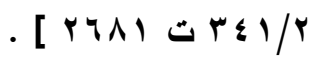

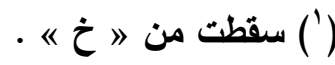

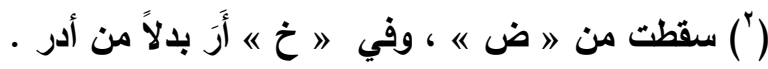

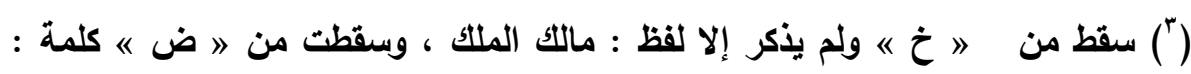

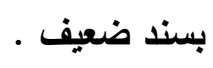

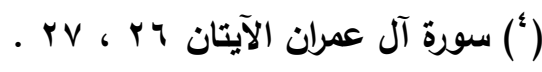

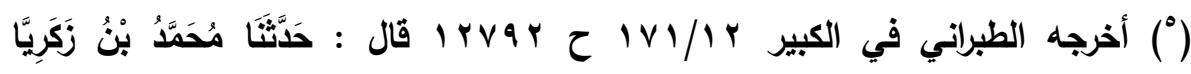

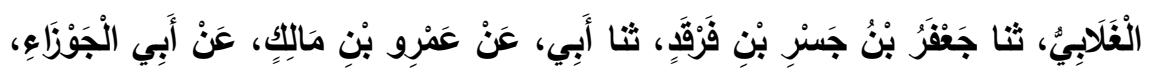

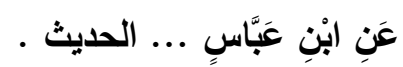

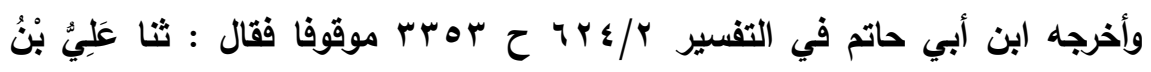

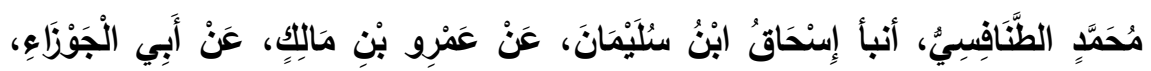

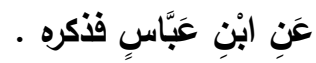

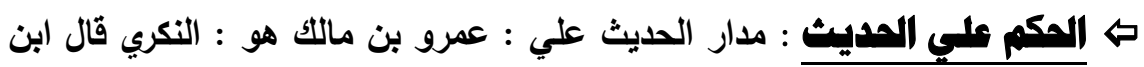

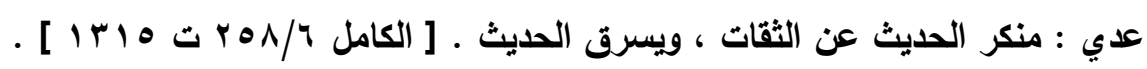

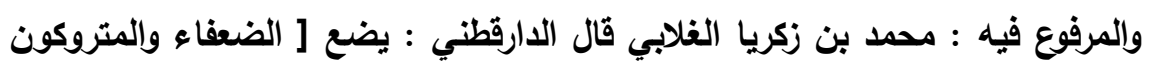

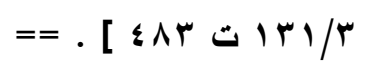




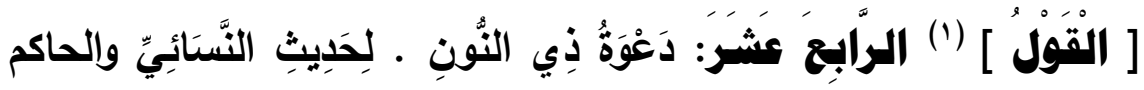

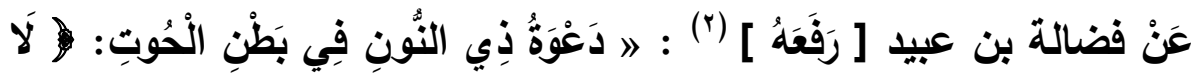

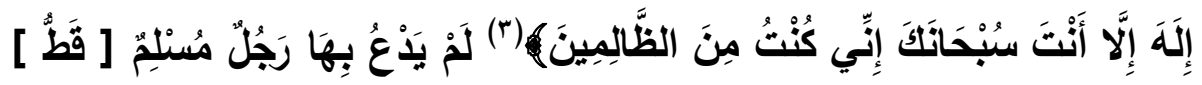

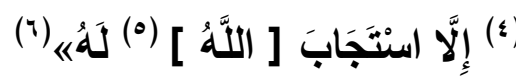

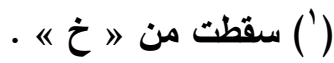

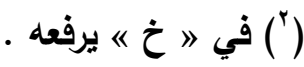

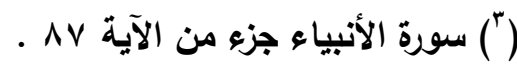

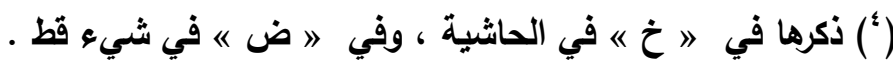

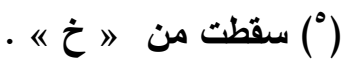

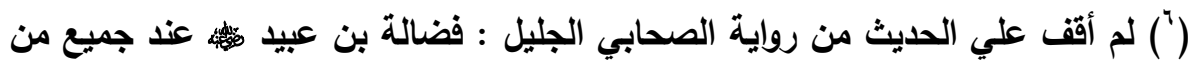

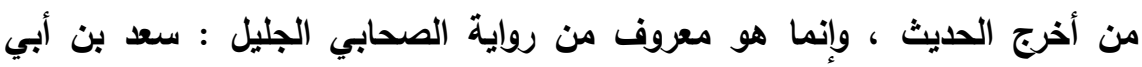

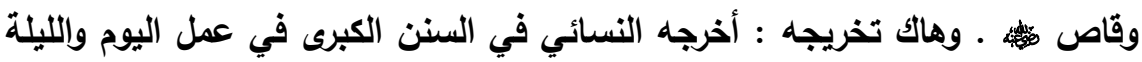

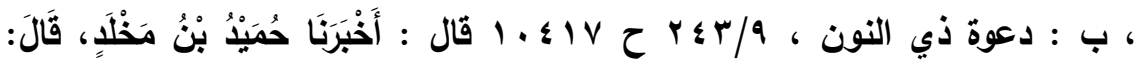

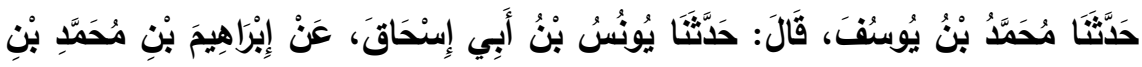

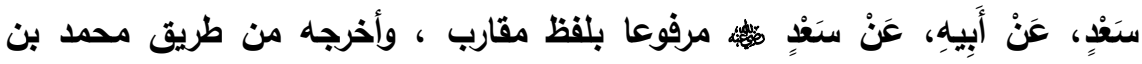

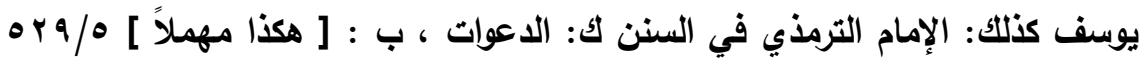

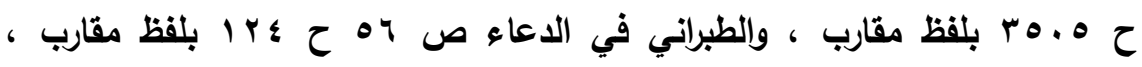

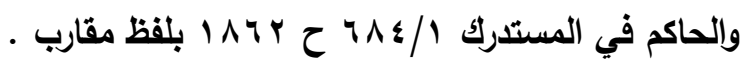
\& وتابع محمد بن يوسف الفريابي : إسماعيل بن عمر الواسطي أخرجه الإمام أحمد

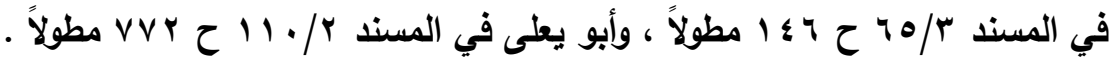




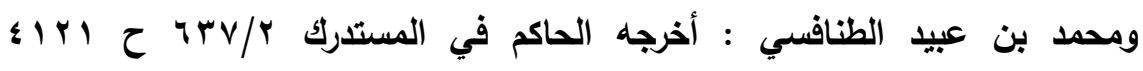
مطولاًا $=$

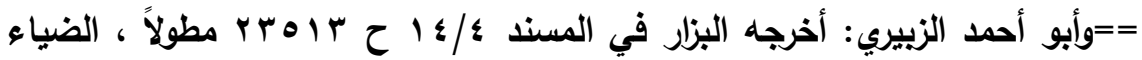

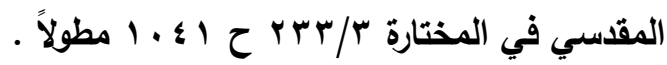

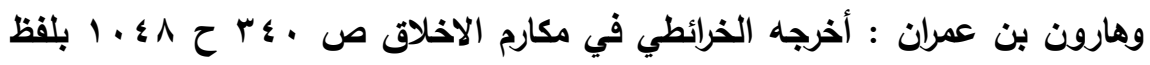

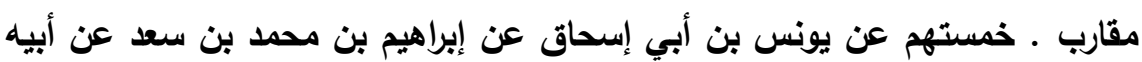

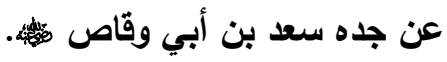
E فمدار الحدبث علي : يونس بن أبي إسحاق وقد اختلف فيه ، وهاك ترجمته :

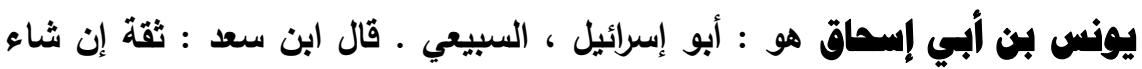

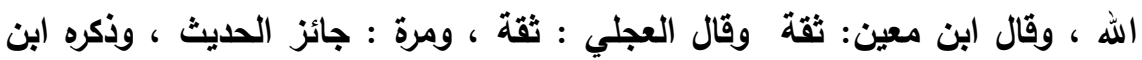

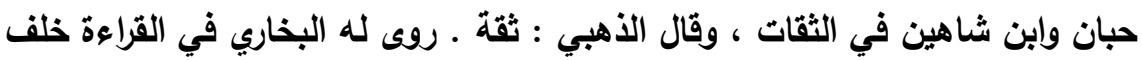

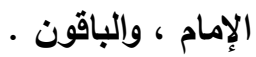
وقال النسائي : ليس به بأس ، وقال ، وقال ابن عدي : لله أحاديث حسان ، وقال الساجي : صدوق ، وقال الحافظ ابن حجر : صدوق يهم قليلاً . وقال يحيي القطان : كانت فيه غقلة ، وكانت فيه سجية كان يقول كان أبي ، وقان ، وقال

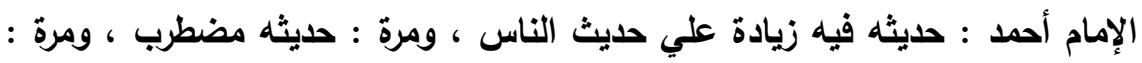

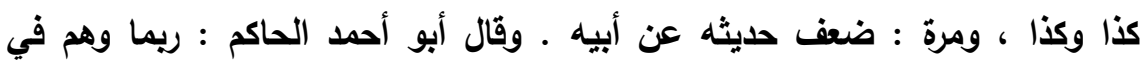

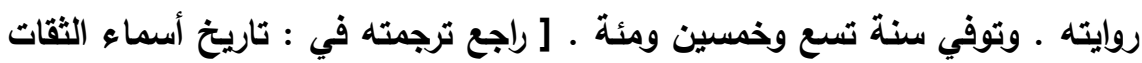

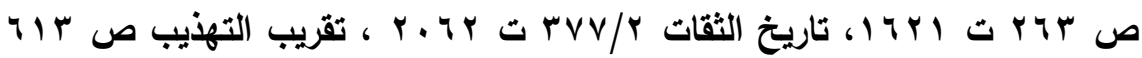

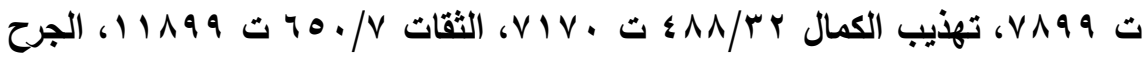

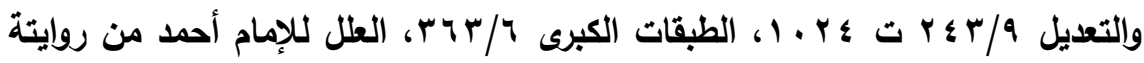

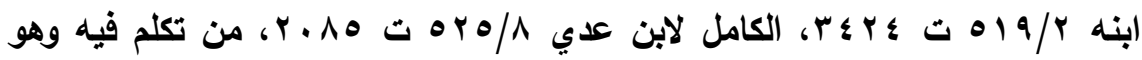

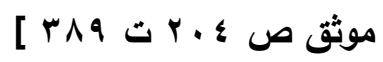




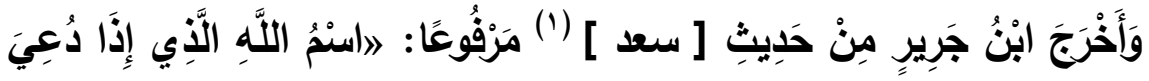

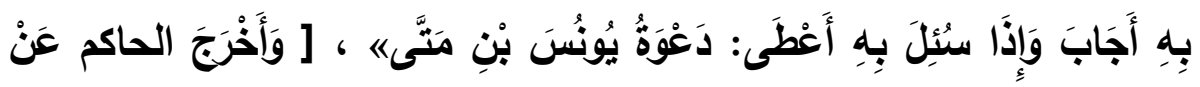

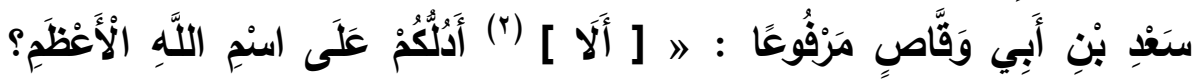

همه قلت : تكلم في روايته عن أبيه خاصة ، كانت فيه سجية كان يقول حدثي أبي

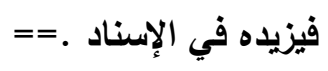

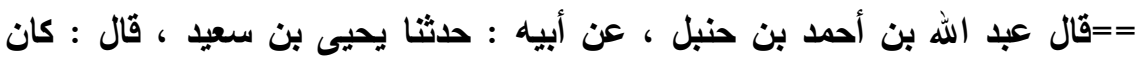

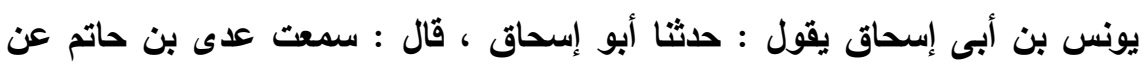

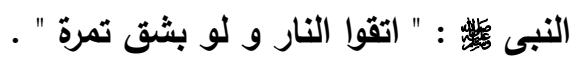

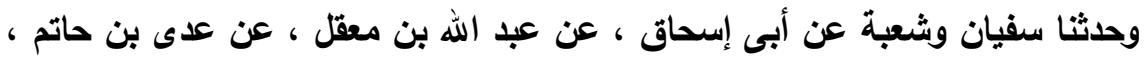

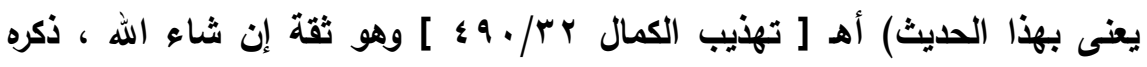

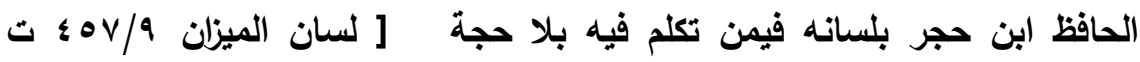
. [riso

مه المكم علي المديث : إسناد الإمام أحمد صحيح رجاله رجال الصحيح عدا

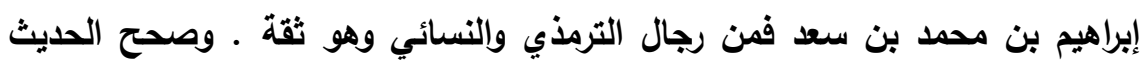

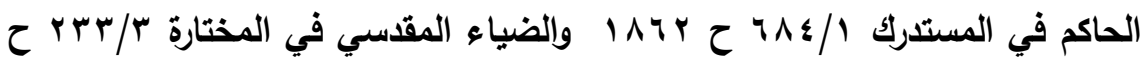

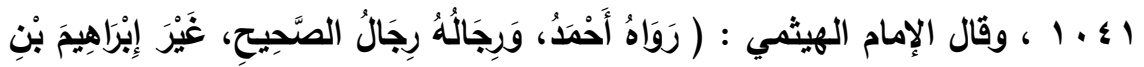

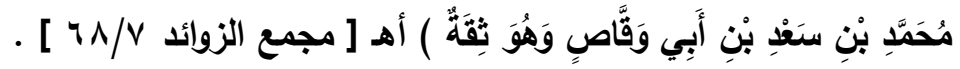

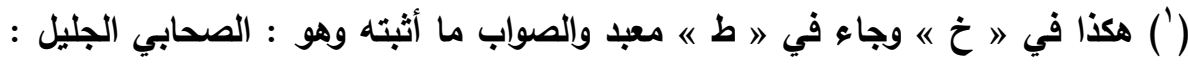
سعد بن مالك أخرجه ابن جرير في تفسيره " جامع البيان عن تأويل آي آلقاب القزآن

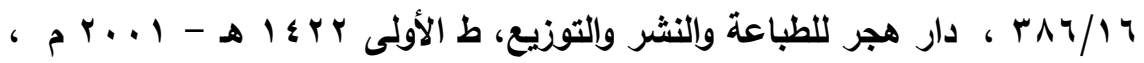

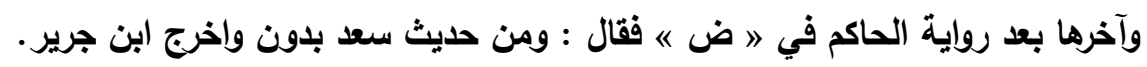

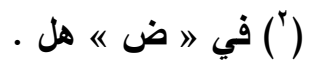




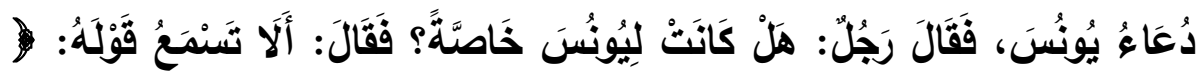

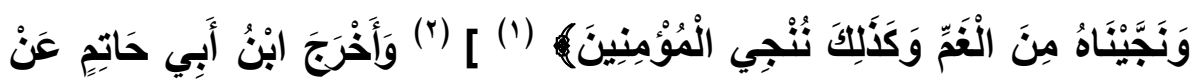

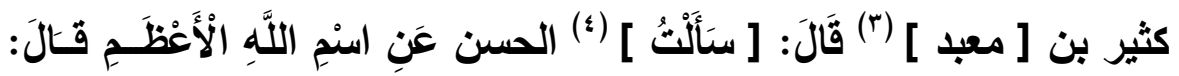

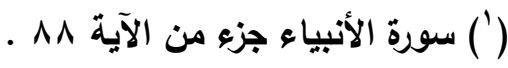

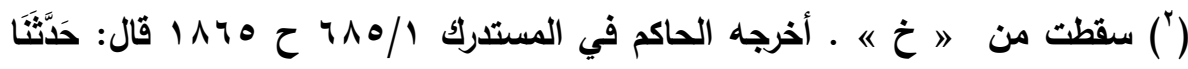

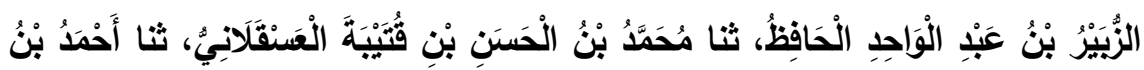

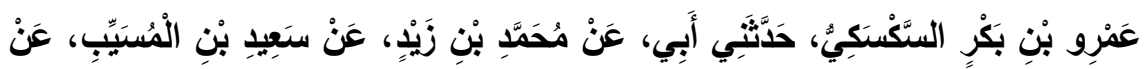

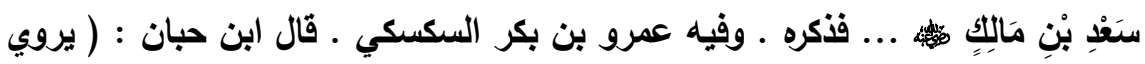

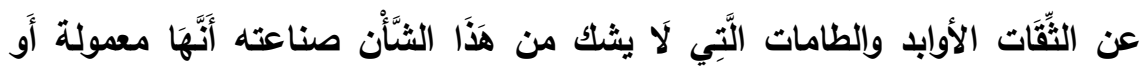

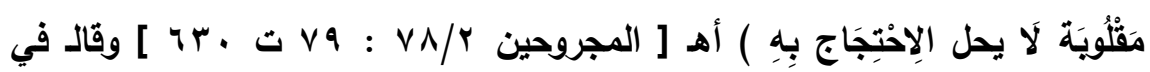

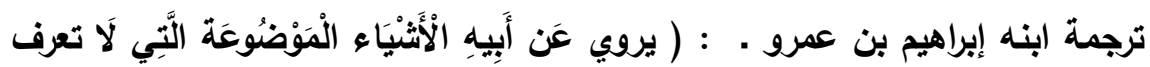

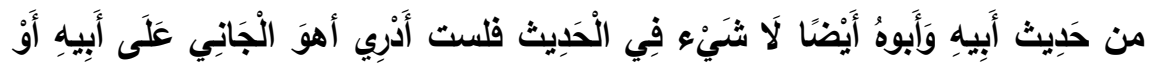

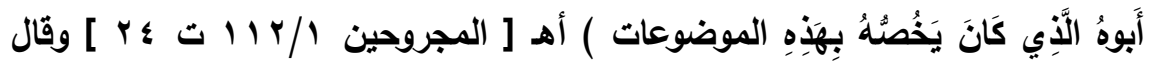

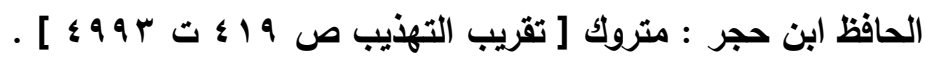

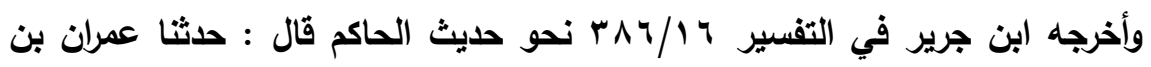

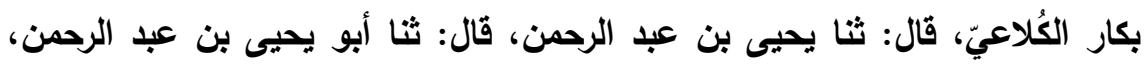

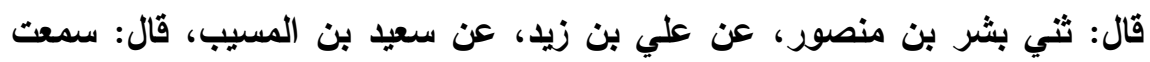

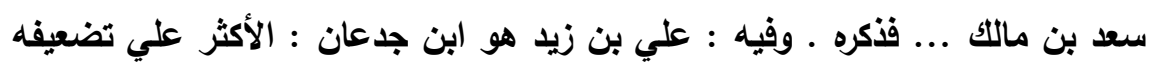

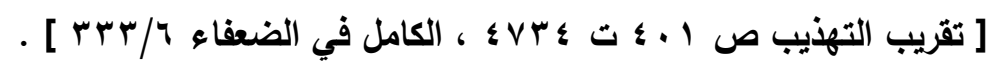

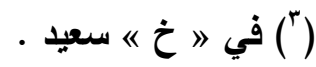

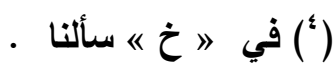




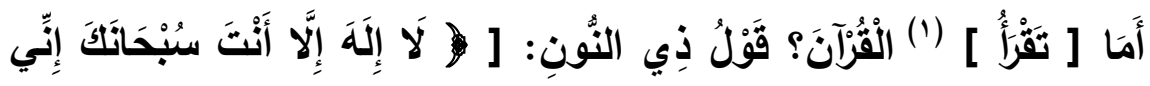

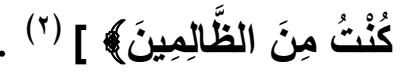

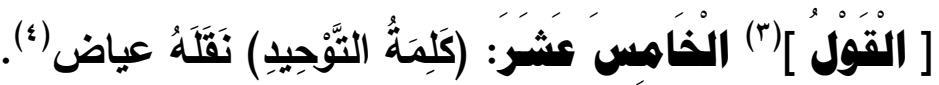

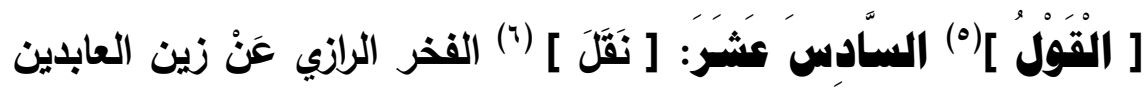

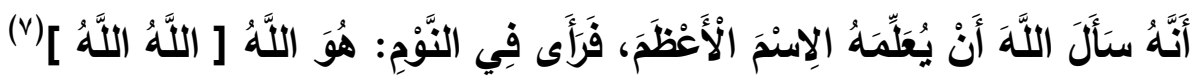

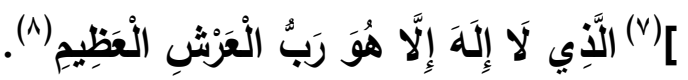

$$
\text { (') (') سقطت من " خ خ خ وقال : هذا. }
$$

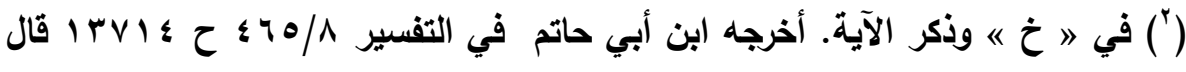

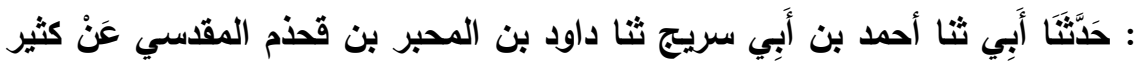

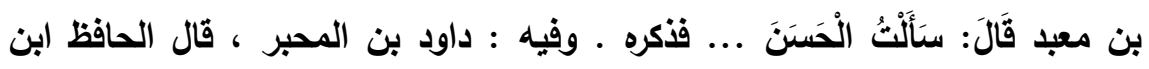

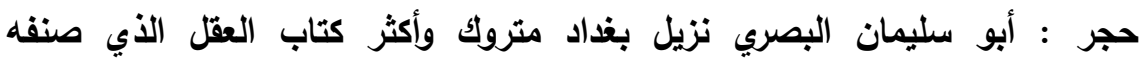

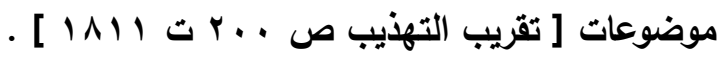

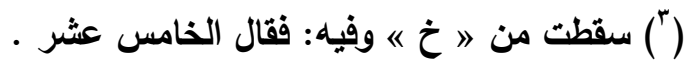

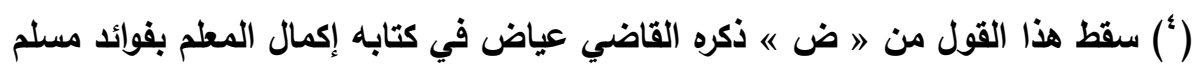

$$
\begin{aligned}
& \text { 19r/A }
\end{aligned}
$$

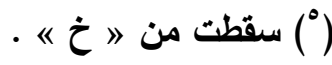

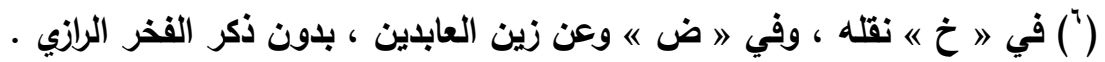

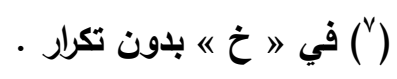

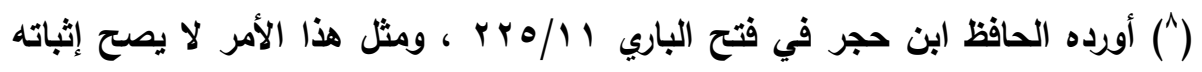

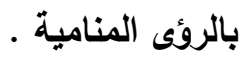

or.

جلم كلية اصول الدين والدعوة / العدد السادس والثلاثون ^ / ـ آم ـ الجزء الاول 


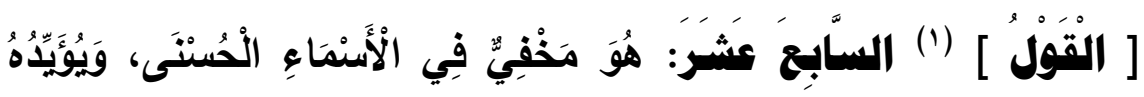

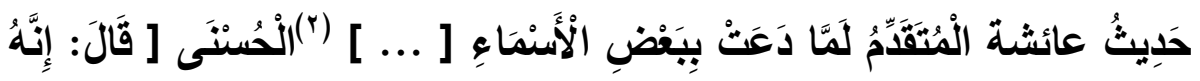

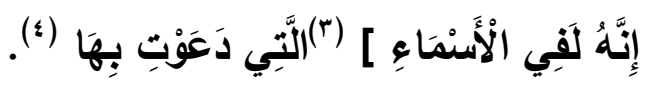

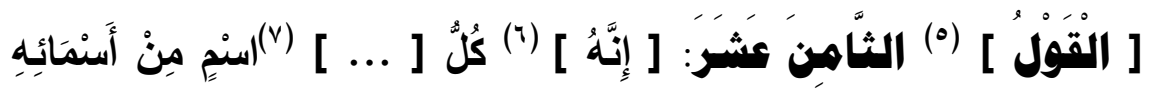
أَسْمَائهِهِ تَعَالَىى [ . [ ]

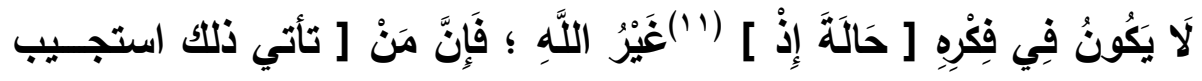
(Ir) [י]

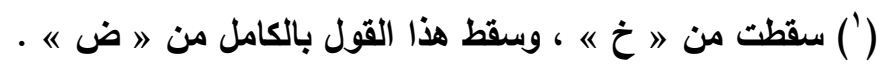

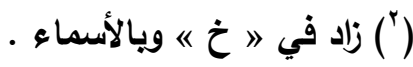

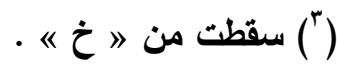

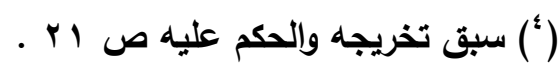

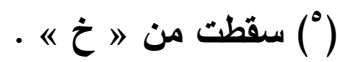

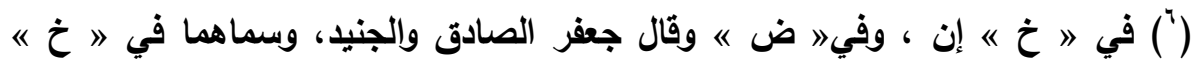
عقب القول فقال : قاله جعفر الصادق والجنيد وغيرهما.

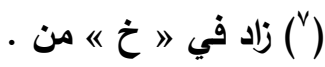

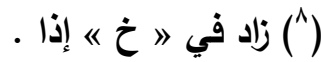

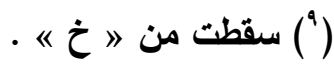

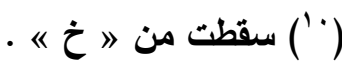

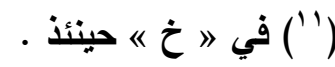

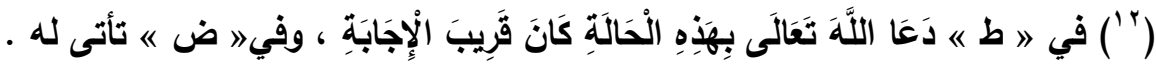




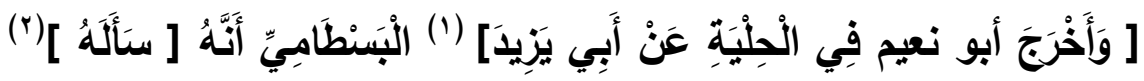

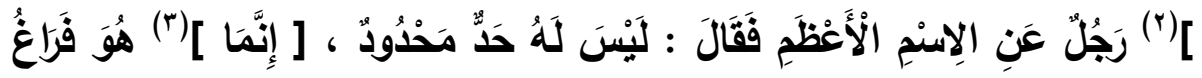

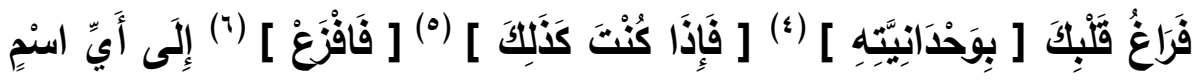

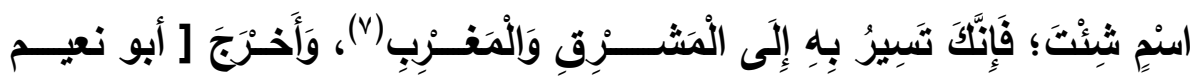

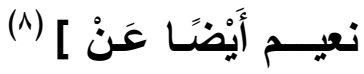

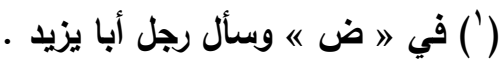

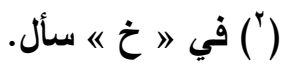

$$
\begin{aligned}
& \text { (") }
\end{aligned}
$$

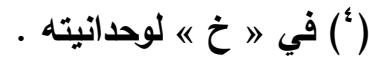

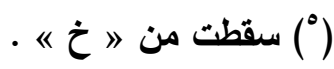

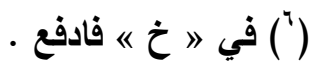

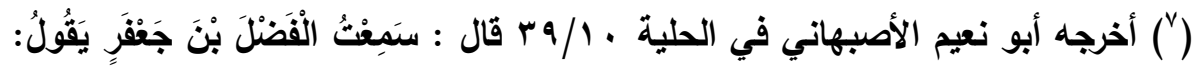

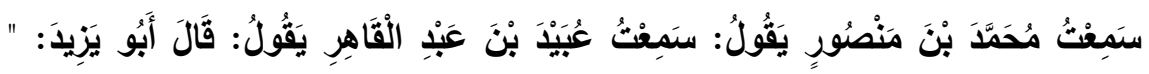

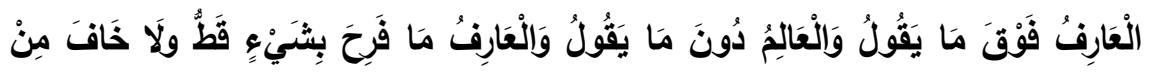

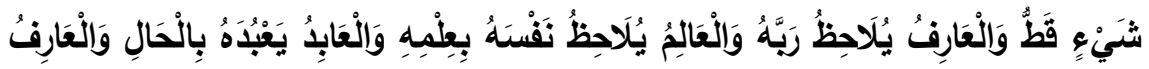

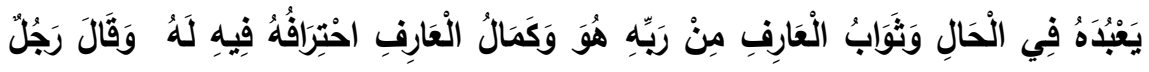

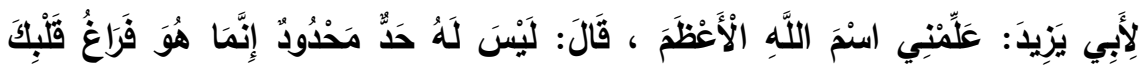

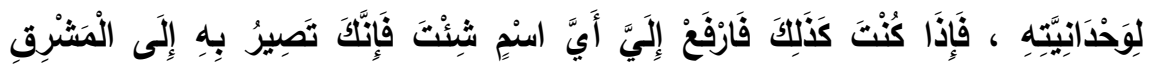

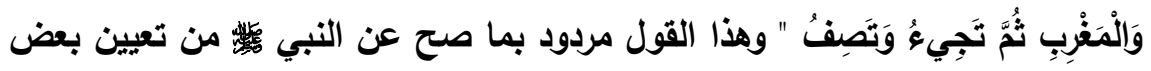
الأسماء ، وفي الإسناد عبيد بن عبد القاهر لم أقق عليه .

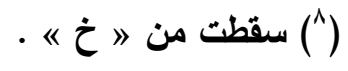

\section{OrY}

جلم كلية اصول الدين والدعوة / العدد السادس والثلاثون ^ / ـ آم ـ الجزء الاول 


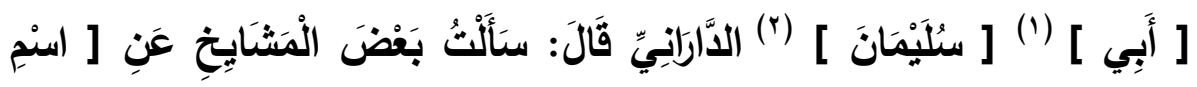

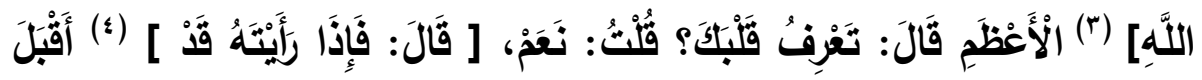

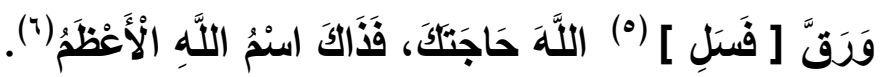

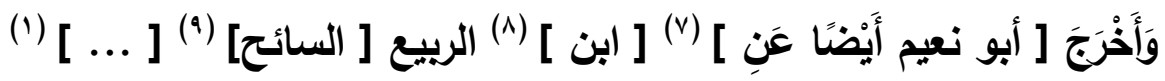

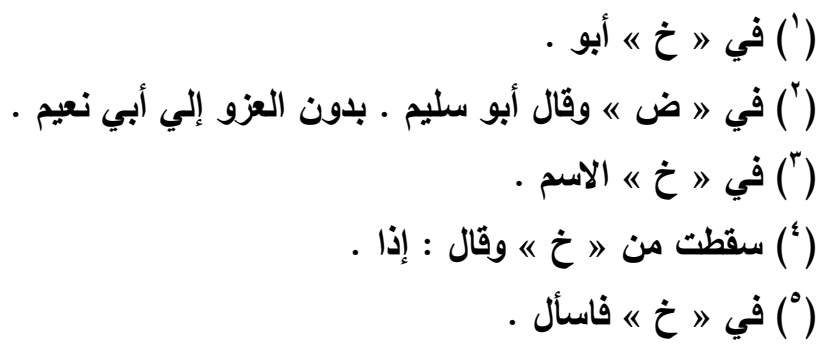

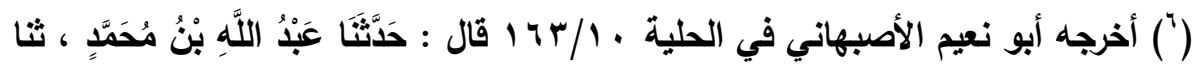

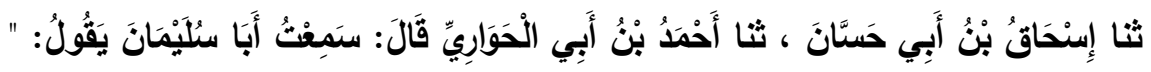

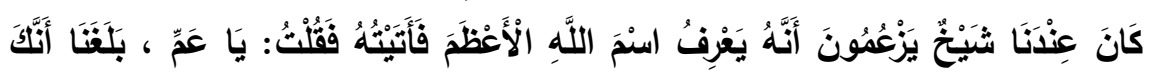

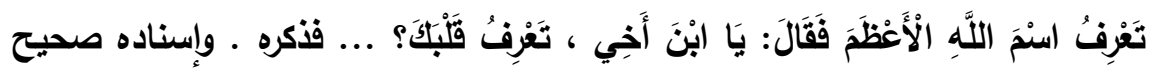

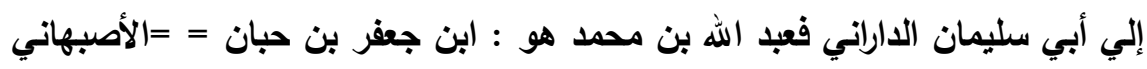

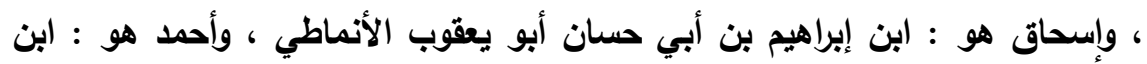
عبد الله بن ميمون بن أبي الحواري . لمان

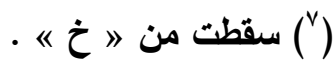

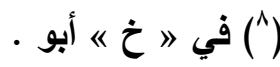

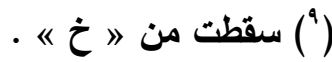




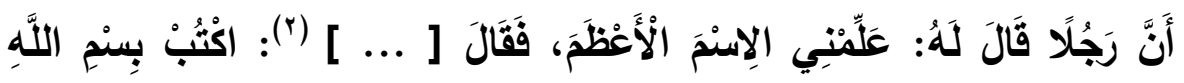
.

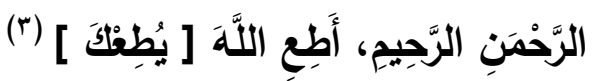

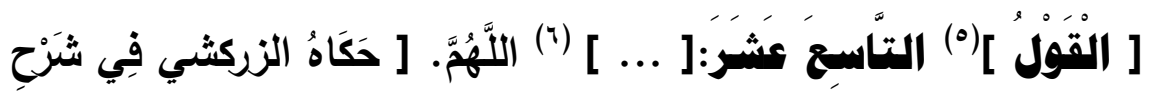

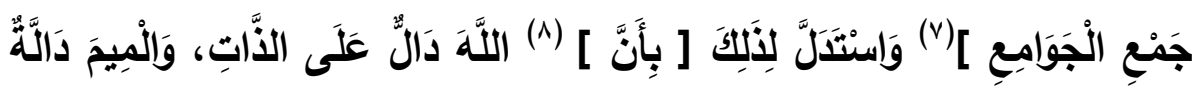

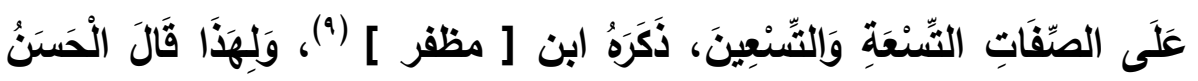

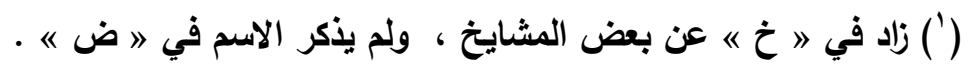
(")

. (")

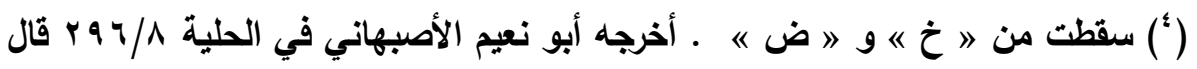

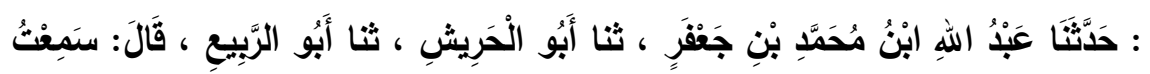

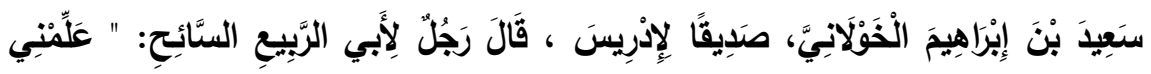

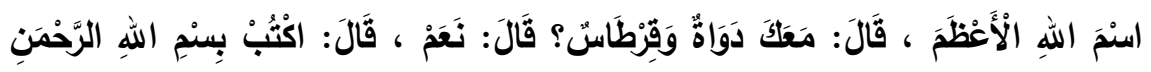

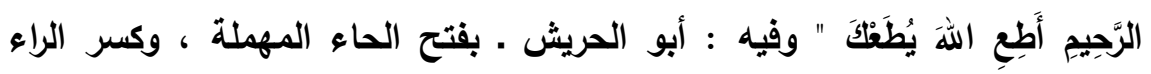

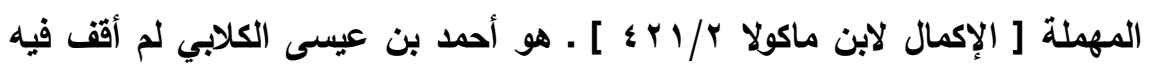

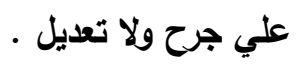

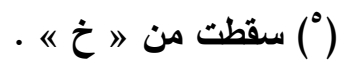

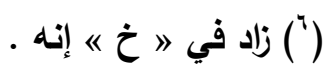

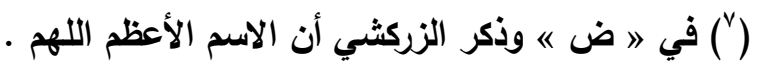

.

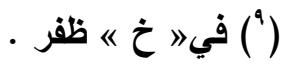

\section{OY}

جلمة كلية اصول الدين والاعوة / العدد السادس والثلاثتون ^1 ا ب بم ـ الجزء الاول 


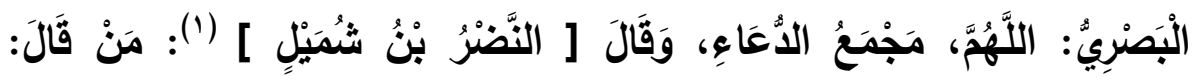

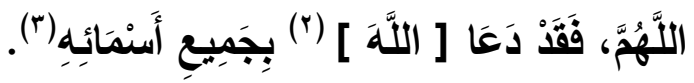

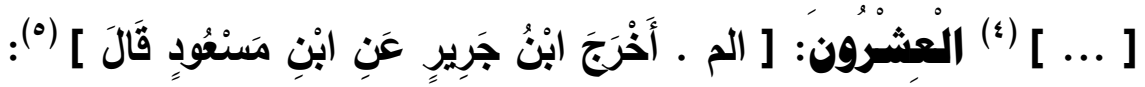

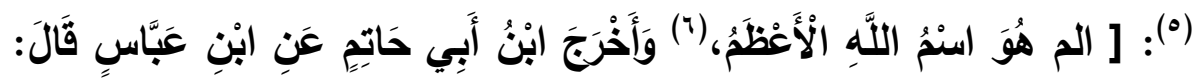

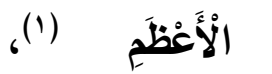
اللَّهِ
أَسْنَمَاعِ

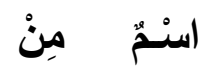
(v) [قَالَ: [ ]

(') في " خ " النصر . بمهيلة . بن شمل ـ بدون الياء آخر الحروف ـ وسقطت من "

$$
\begin{aligned}
& \text { ض «" }
\end{aligned}
$$

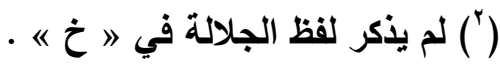

(") أورده القرطبي في التفسير \&/ءه ــ ـ وقال ابن القيم في التفسير : ( وقد وجه طائفة

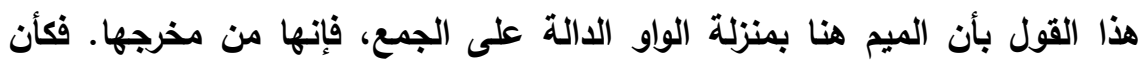

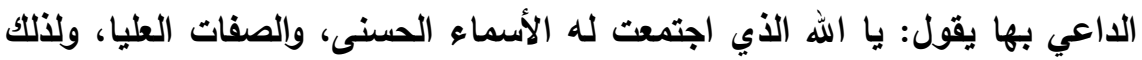

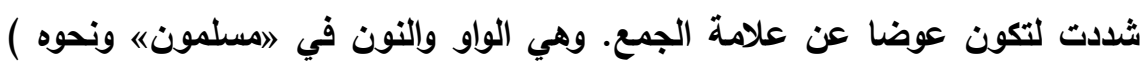

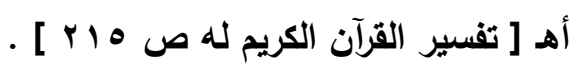

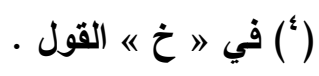

(") سقطت من 》 خ خ عقال : قال عبد الله بن مسعود ، وقال في " ض « وقال ابن

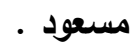

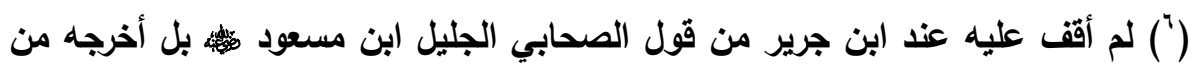

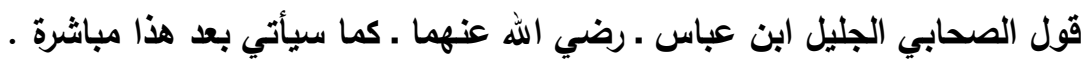

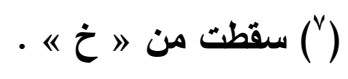




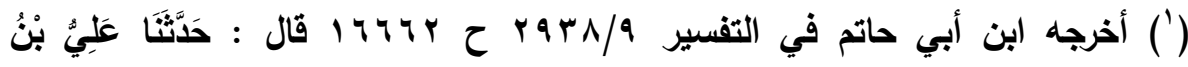

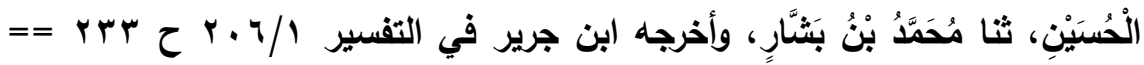

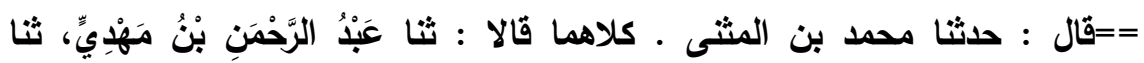

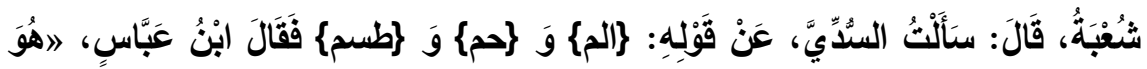

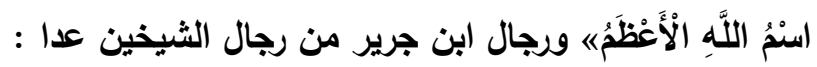

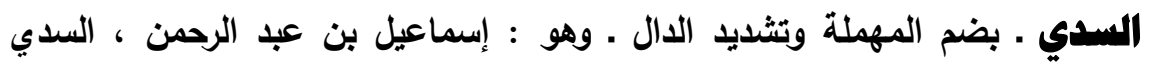

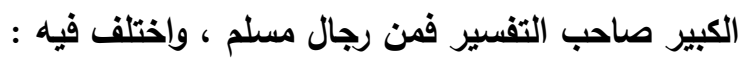

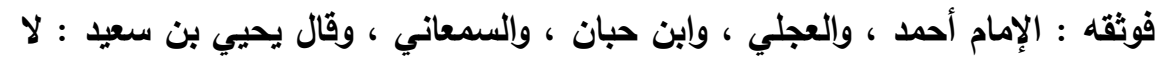

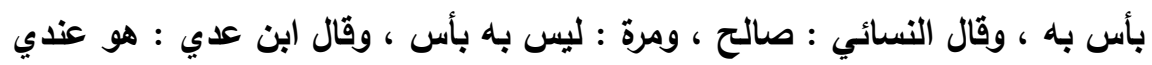

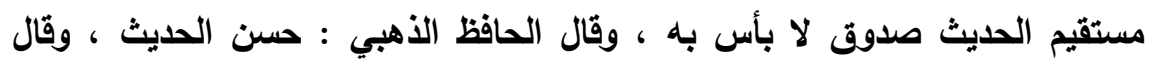

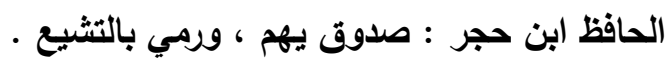
وضعفه ابن معين ، وقال أبو زرعة : لين ، وقال الطبري : لا يحتج بحديثه ، وقئ ، وقال

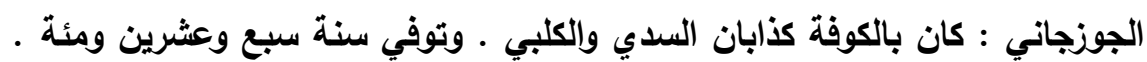

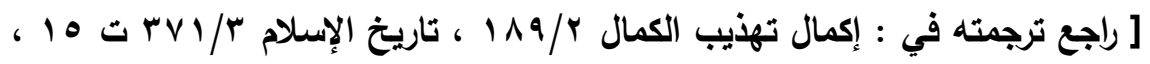

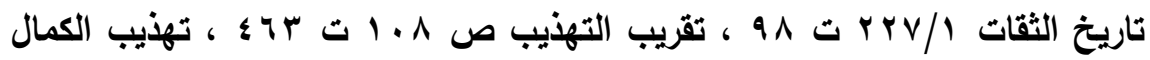
r/r

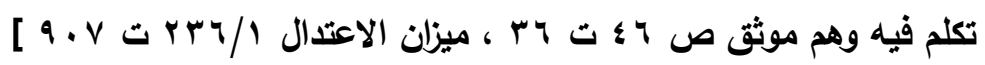
كهِ قلت : هو حسن الحديث ، ولعل الجوزجاني يقصد : بالسدي : الصغير ، واسمه

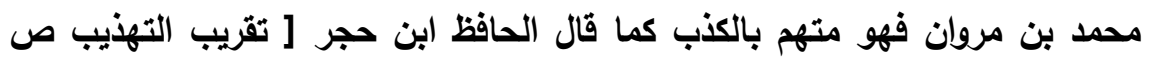

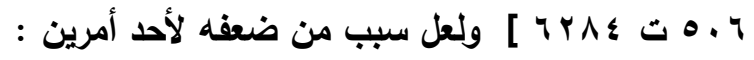

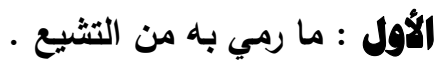




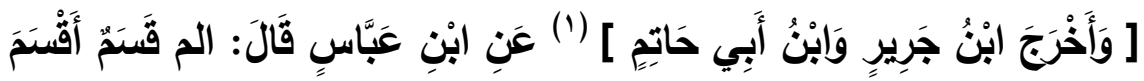

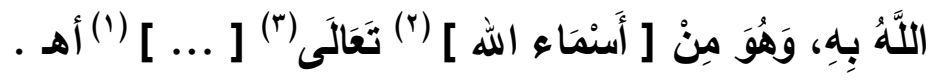

الثاني : بسبب ما تكلقه من أسانيد في تفسيره كما ذكره الإمام أحمد فقال : ( إنه

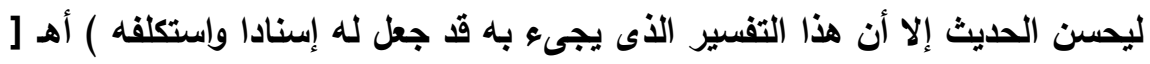

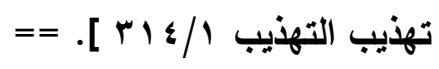

=="وقال ايضاً في العلل r/ ع بr من رواية ابنه : (حدثنا أبو أحمد وهو الزبيري قال

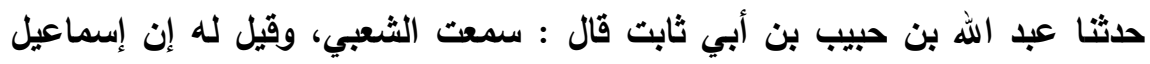

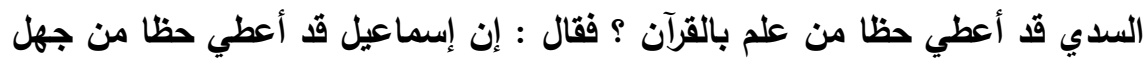
بالقرآن ) أه .

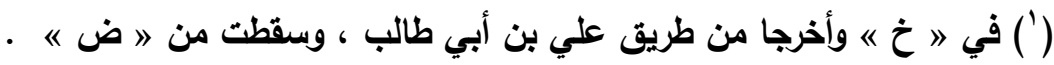

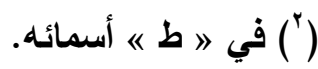

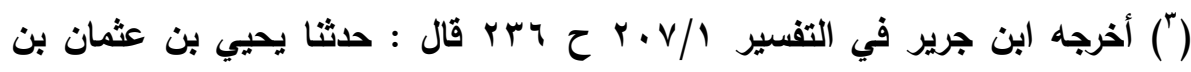

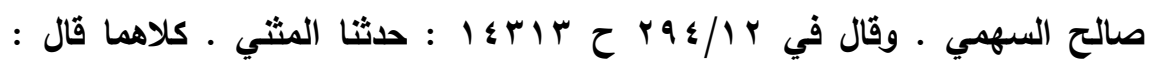

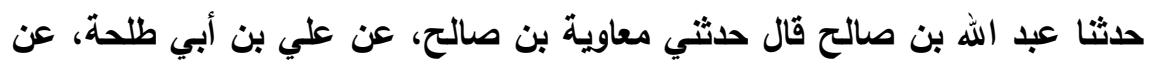

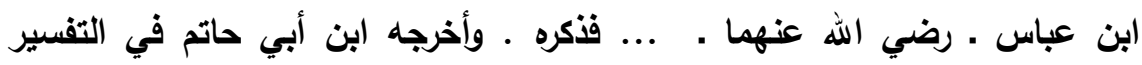

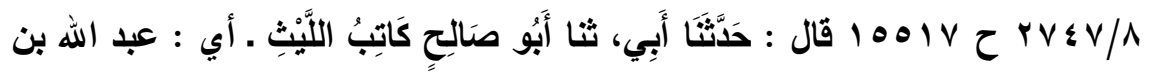
صالح · ( به ) · والإسناد منقطع فيه : علي بن أبي طلحة لم يسمع من ابن عباس .

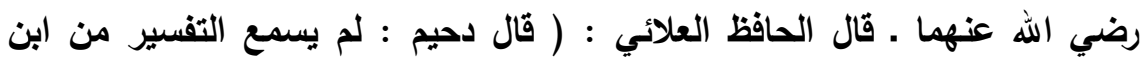

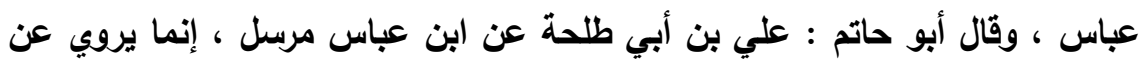

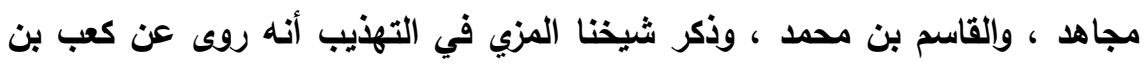

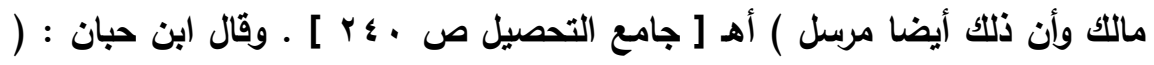




\section{الخــاتمة}

الحمد لله الأي بنعمته ثتم الصالحات ، وأثكره تعالى إذ من علي بإتمام هذا العمل المبارك فبعد أن عشت مع هذا الجزء الحديثي الهام ، ومع الإمام السيوطي - رحمه الله تعالى . أختم هذا البحث بأبرز النتائج التي توصلت

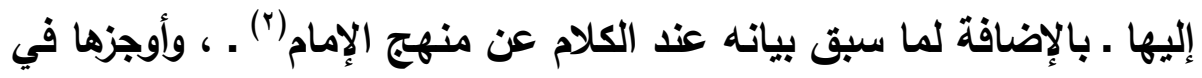
النقاط التالية : النالية

ا ـ إخراج هذه الرسالة التي تعد كنزا من كنوز العلم إلى النور ، وتحقيقها

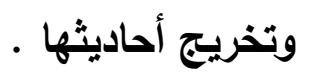

r. الوقوف علي ما كان عليه الحافظ السيوطي من سعة علم ، وتبحر في الحديث خاصة ، وما رزقه الله من قرة علمية على التوفيق بين

المسائل الشائكة .

r. بيان كل ما ورد في اسم الله الأعظم ، ودليل كل قول .

ع. بيان مهارة الحافظ السيوطي في استقصاء الأقوال ، وجمع الأدلة.

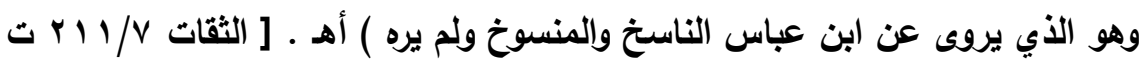
- [ q V r

( ') زاد في " خ " تم الكتاب بحمد الله وعونه وصلى الله على سيدنا محمد وآله وصحبه وسلم .

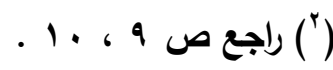




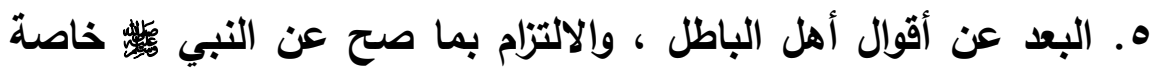

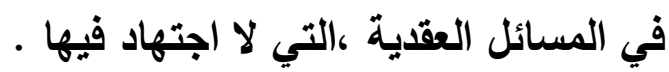

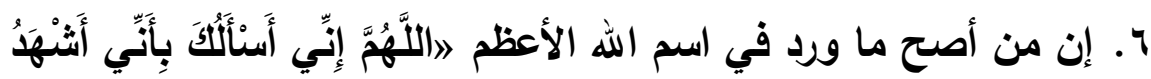

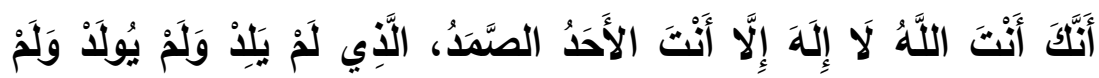

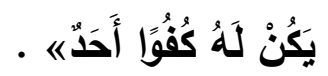

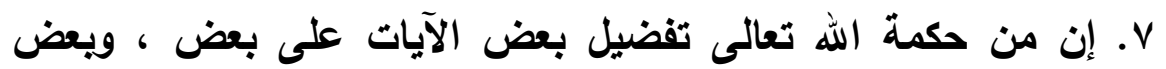

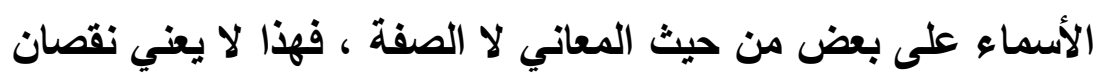
المفضول . 


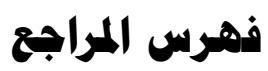

ا. أحوال الرجال لإبراهيم بن يعقوب الجوزجاني ت

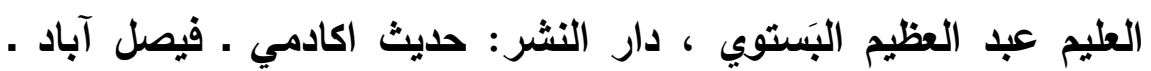

• باكستان

ץ. إكمال [ تهذيب الكمال في أسماء الرجال للحافظ المزي ] للإمام أبي عبد الله علاء الاين مغلطاي ابن قليج بن عبد الله ت r r عادل بن محمد ، وأسامة بن إبراهيم ، مطبعة الفاروق الحديثة للطباعة

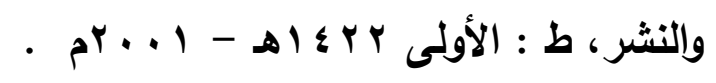

r. الاتقان في علوم القرآن للإمام أبي الفضل جلال الدين السيوطي ت 11 91 هـ ، تحقيق : محمد أبي الفضل إبراهيم ، الهيئة المصرية للكتاب ،

$$
\text { - م) } 9 V \leq-\infty 1 T 9 \varepsilon
$$

ع. الأسماء والصفات للإمام أبي بكر أحمد بن الحسين بن علي بن موسىى

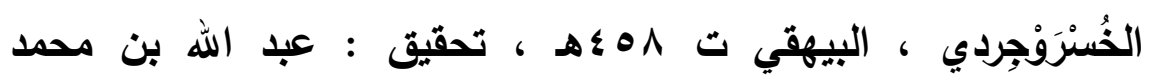

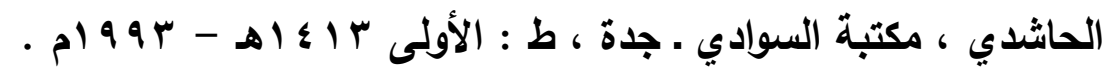

هـ الأمالي الخميسية للإمام يحيى بن الحسين الثجري الجرجاني ت 99 ؛ هـ ، بترتيب القاضي محيب الدين محمد بن أحمد القرشي ت • 1 آهـ ،

$$
\begin{aligned}
& \text { or. }
\end{aligned}
$$

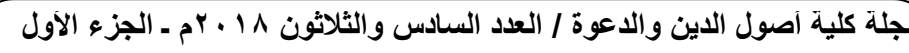


تحقيق: محمد حسن محمد حسن إسماعيل ، دار الكتب العلمية ـ بيروت ،

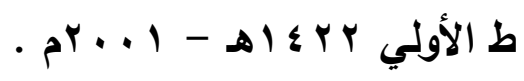

7 . الأنساب للإمام أبي سعد عبد الكريم بن محمد بن منصور السمعاني ، ت ץ צهـ ، تحقيق : عبد الرحمن بن يحيى المعلمي ، نشرته : مجلس دائرة

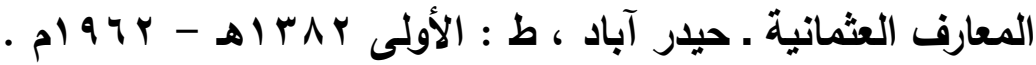

V. بحر الام فيمن تكلم فيه الإمام أحمد بمدح أو ذم للإمام يوسف بن حسن بن عبد الهادي الصالحي ابن ابن المِبْرَد الحنبلي ت 9 ـ 9ه ، تحقيق د/ روحية عبد الرحمن السويفي ، دار الكتب العلمية ـ بيروت ، ط: الأولى

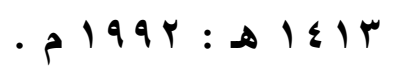

^. بيان الوهم والإيهام في كتاب الأحكام للإمام علي بن محمد أبي الحسن بن القطان ت ^ ^ 7 هـ، تحقيق : د//الحسين آيت سعيد ، دار طيبة - الرياض

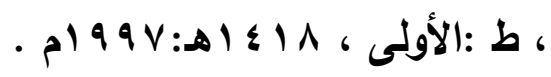

9 ه. البداية والنهاية للإمام أبي الفداء إسماعيل بن عمر بن كثير ت \&VV تحقيق : علي شيري دار إحياء التراث العري،، ط : الأولى ^ · ع اه هـ : $\cdot \operatorname{ro\Lambda \Lambda }$

• 1 البلر الطالع بمحاسم ما بعد القرن السابع للإمام محمد بن علي

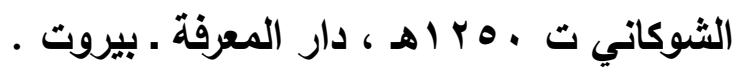


1 1 ـ تاريخ الثقات للإمام أبي الحسن أحمد بن عبد الله بن صالح العجلى ث

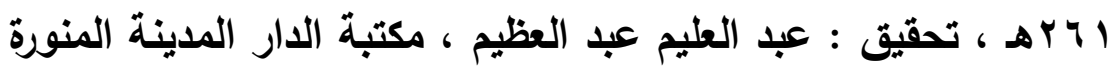

$$
\text { ، ط : الأولى، 0. }
$$

r ا. تاريخ بغداد للحافظ أبي بكر أحمد بن علي الخطيب البغدادي ت

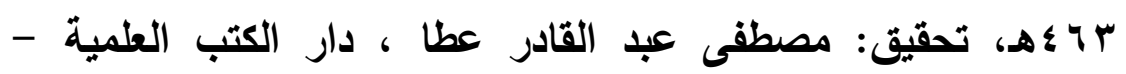

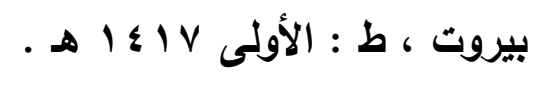

سا ـ تاريخ دمشث للحافظ أبي القاسم علي بن الحسن . المعروف بابن

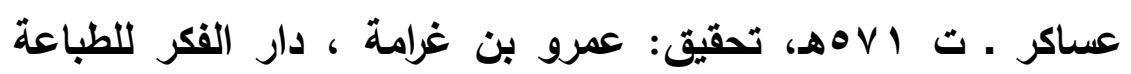

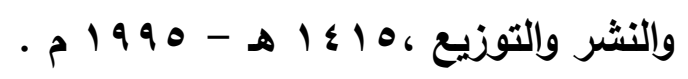

ع ا ـ تقريب التهذيب للحافظ أبي الفضل أحمد بن علي بن حجر العقلاني ت rهـ ، تحقيق : محمد عوامة ، دار الرشيد - سوريا ، ط : الأولى،

$$
\text { . } 19 \wedge 7: 1 \leq \cdot 7
$$

ه ـ تهذيب التهذيب للحافظ أبي الفضل أحمد بن علي بن حجر العسقلاني

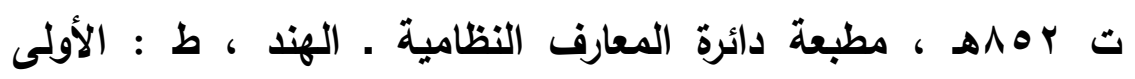

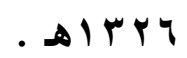

ا 1 . تهذيب الكمال للحافظ أبي الحجاج يوسف بن عبد الرحمن المزي ت

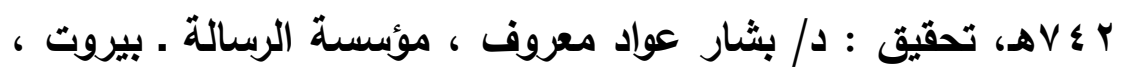

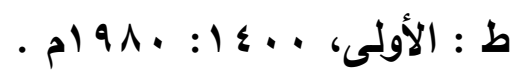

\section{OrY}

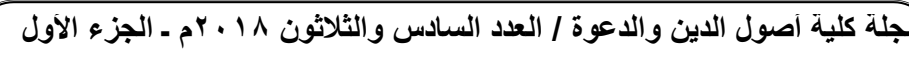




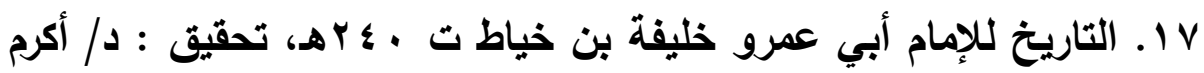

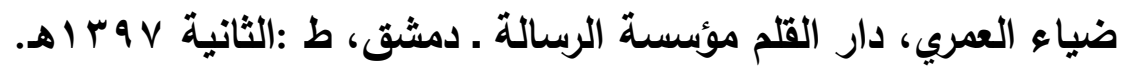

1 1. التاريخ الكبيز للإمام أبي عبد الله محمد بن إسماعيل البخاري ت צYه r ، تحقيق : محمد عبد المعيد خان ، دائرة المعارف العثمانية .

$$
\text { هيدر آباد مه }
$$

9 1 ـ التقييد والايضاح شرح مقدمة ابن الصلاح للحافظ أبي الفضل زين الدين

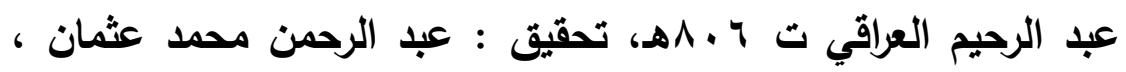

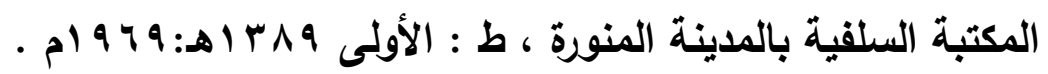
• r. الثقات للحافظ أبي حاتم محمد بن حبان البُستي ت عهـه، تحقيق : محمد عبد المعيد خان ، دائرة المعارف العثمانية بحيدر آباد الاكن .

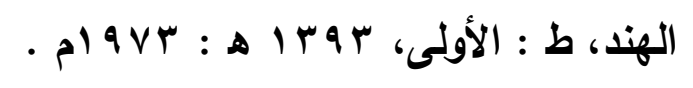

ا Y. الثقات ممن لم يقع في الكتب الستة للحافظ أبي الفداء زين الدين قاسم بن قُطْوُيَغَا الحنفي ت هV هـ، تحقيق: شادي بن محمد بن سالم آل نعمان ، مركز النعمان للبحوث والاراسات الإسلامية وتحقيق التراث

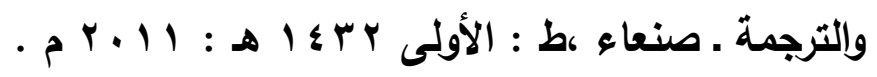

Y Y. الجرح والتعديل للإمام أبي محمد عبد الرحمن بن محمد بن أبي حاتم

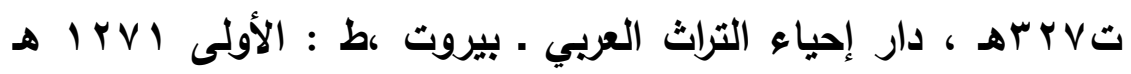
- $190 \mathrm{r}$ : 


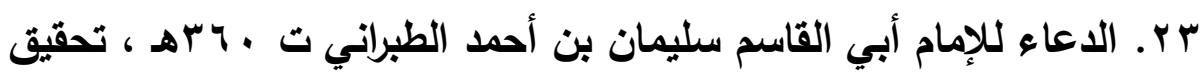

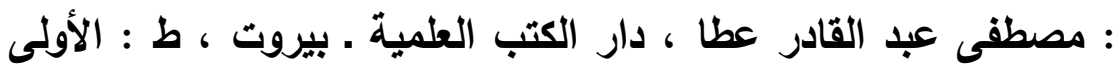

צ r. ذخيرة الحفاظ لأبي الفضل محمد بن طاهر ـ المعروف بابن القيسراني .

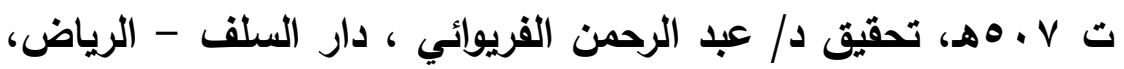

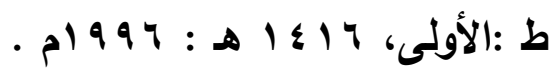

Or. . سؤالات السلمي للارقطني للإمام محمد بن الحسين أبي عبد الرحمن

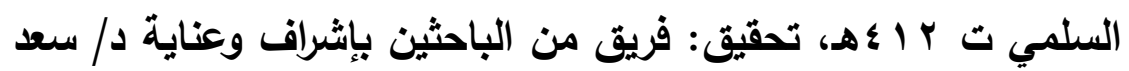

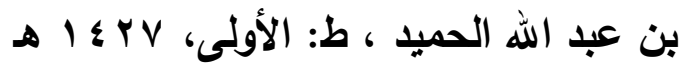
\ץ. سير أعلام النبلاء للإمام شمس الدين محمد بن أحمد الذهبي ت

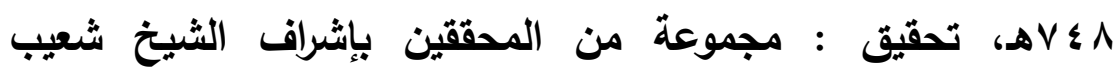

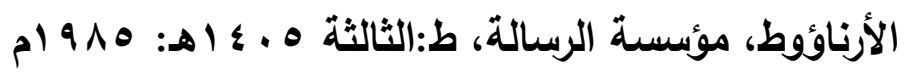

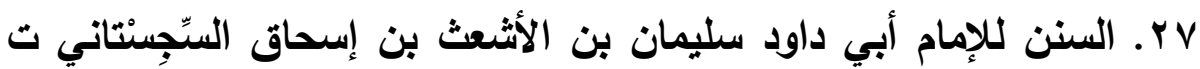

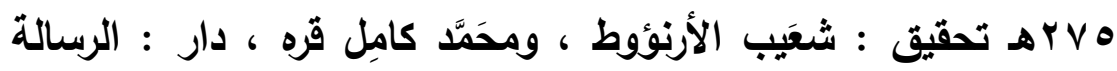

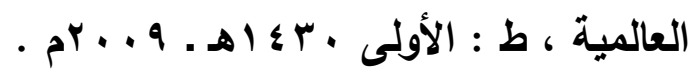
א. السنن للإمام أبي عيسي محمد بن عيسى بن سَوْرة ، الترمذي ت

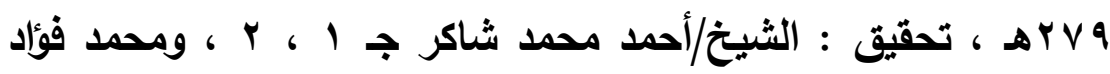

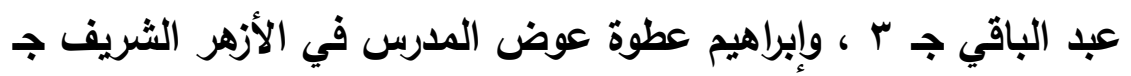

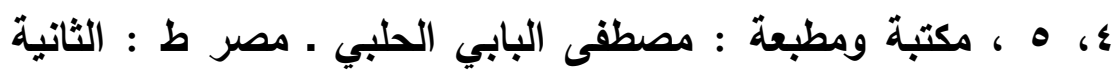

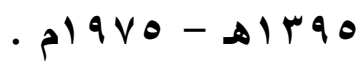
OT\& جلملة كلية اصول الدين والدعوة / العدد السادس والثلاثون ^1 ـ بام ـ الجزء الاول 
q. السنن للإمام أبي عبد الله محمد بن يزيل ، ابن ماجة القزويني ت

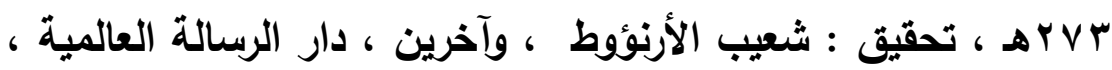

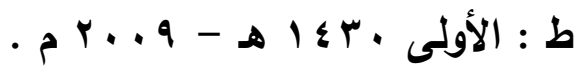

• r. السنن للإمام أبي محمد عبد الله بن عبد الرحمن بن الفضل بن بَهرام

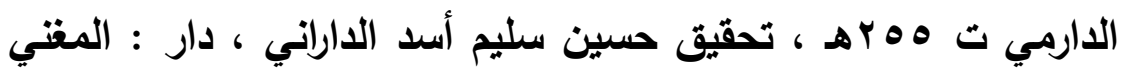
للنشر والتوزيع ـ المملكة العربية السعودية ، ط : الأولى ب إعـ هـ -

$$
\text { - } r \text {... }
$$

اس. السنن للإمام أبي الحسن علي بن عمر الارقطني ث هیrهـ ،تحقيق : شعيب الأرنؤوط، وآخرين، مؤسسة الرسالة . بيروت ،ط : الأولى،

$$
\text { . } r \text {. }
$$

ץ r. السنن الكبرى للإمام أحمد بن الحسين أبي بكر البيهقي ت ^هـ هـ، تحقيق : محمد عبد القادر عطا، دار الكتب العلمية ـ بيروت ، ط :الثالثة

$$
\text { • } r \text { r... }
$$

سr. شذرات الذهب في أخبار من ذهب للإمام عبد الحي بن أحمد بن العماد الحنبلي ت 19 • اهـ، تحقيق : محمود الأرناؤوط ، خرج أحاديثه: عبد القادر الأرناؤوط ، دار ابن كثير دمشث - بيروت، ط : الأولى 1 . ع ا هـ

$$
\text { ค 19人7: }
$$

ع ا. شرح السنة للإمام أبي محمد الحسين بن مسعود بن محمد بن الفراء البغوي ت 7 أهـ ، تحقيق : شعيب الأرنؤوط ، محمد زهير الشاويش ،

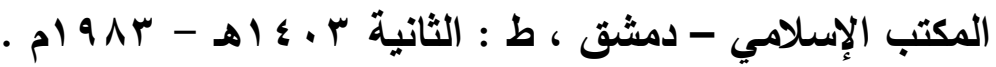


هr. شرح سنن أبي داود للإمام أبي محمد محمود بن أحمد بدر الدين العينى

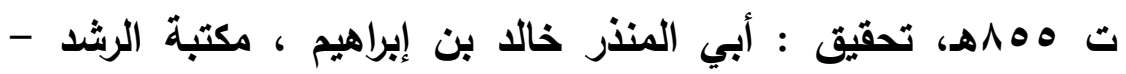

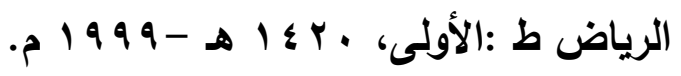

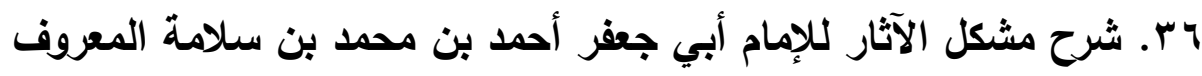

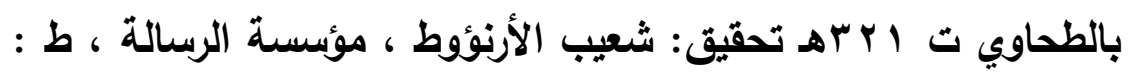

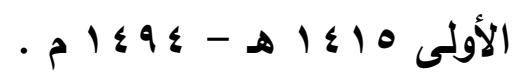

VV. شرح معاني الآثار للإمام أبي جعفر أحمد بن محمد المعروف بالطحاوي

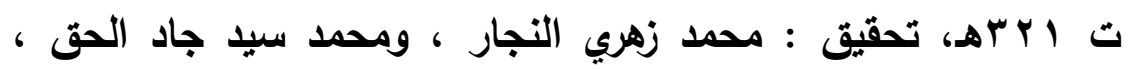

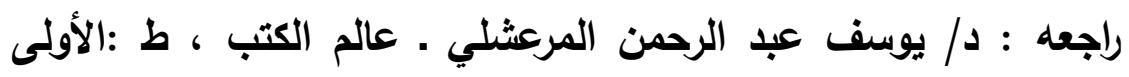

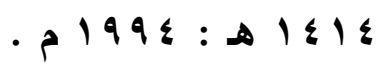

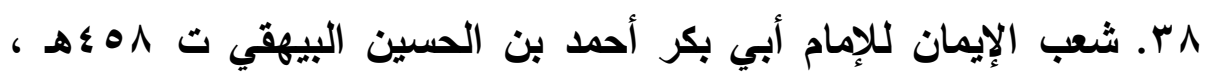

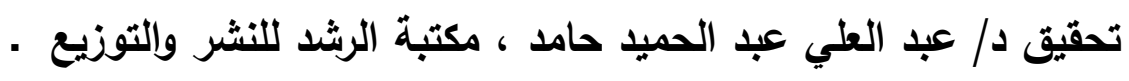

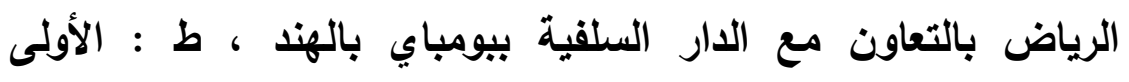

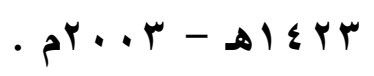

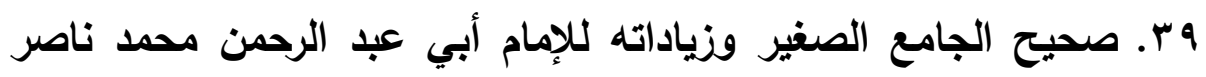

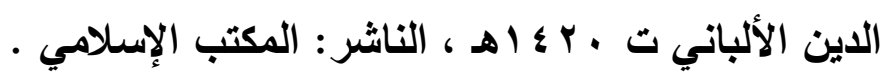

• ؛. صحيح سنن أبي داود للإمام أبي عبد الرحمن محمد ناصر الاين

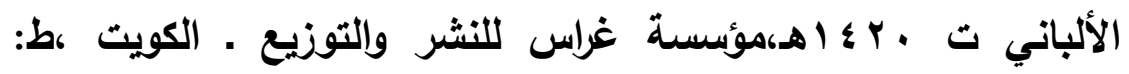

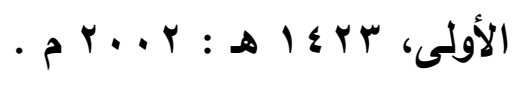


اءـ الضعفاء الصغير للإمام أبي عبد الله محمد بن إسماعيل اتلبخاري ت

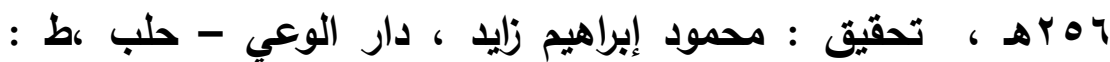

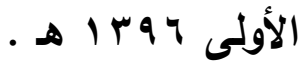

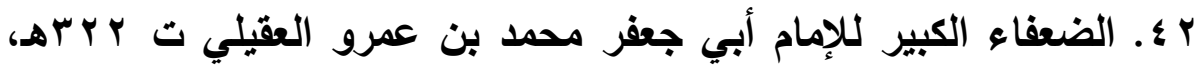
تحقيق :عبد المعطي أمين قلعجي، دار المكتبة العلمية . بيروت ، ط :

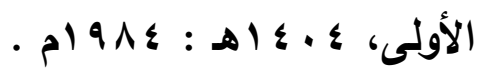

بـ ــ الضعفاء والمتروكون للإمام أبي عبد الرحمن أحمد بن شعيب ، النسائي ت ب. rه ، تحقيق محمود إبراهيم زايد ، دار الوعي . حلب ، ط :

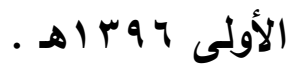

ء ـ الضعفاء والمتروكون للإمام أبي الفرج عبد الرحمن بن علي بن محمد

الجوزي ت Q Vهـ ، تحقيق : عبد الله القاضي ، دار الكتب العلمية .

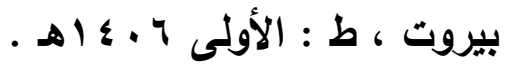

ه ؛ الطبقات الكبرى للإمام أبي عبد الله محمد بن سعد ت . ب هـ، تحقيق: محمد عبد القادر عطا ، دار الكتب العلمية . بيروت ، ط :الأولى،

$$
\text { . 199.: : } 1 \text { : 1 . }
$$

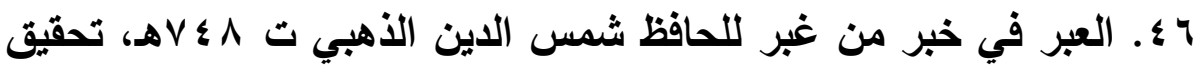
: أبي هاجر محمد السعيد، دار الكتب العلمية ـ بيروت . 


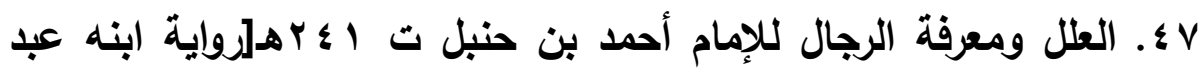

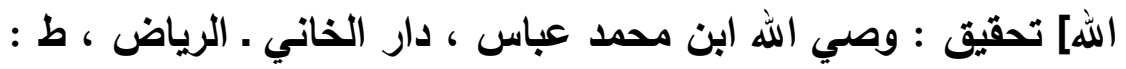

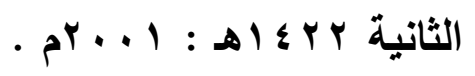

^ــ فتح الباري شرح صحيح البخاري للحافظ أحمد بن علي بن حجر

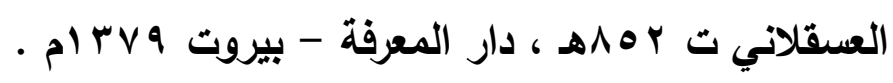

9 ؛ـ فضائل القرآن للإمام أبي بكر جعفر بن محمد بن الحسن الفِريابِي ت 1. أهـ ، تحقيق: يوسف عثمان فضل الله جبريل ، مكتبة الرشد .

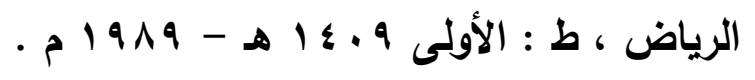

•ه. فضائل القرآن للإمام أبي العباس جَفْفر بن مُحَمَّد بن المُعْتَّز بنِ مُحَمَّد

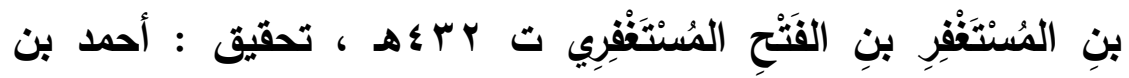

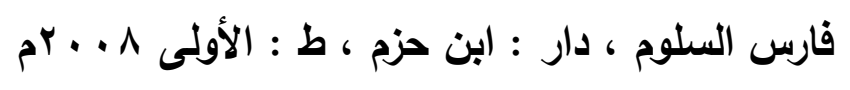

اه. فضائل القرآن وما أنزل من القرآن بمكة وما أنزل بالمدينة للإمام أبي

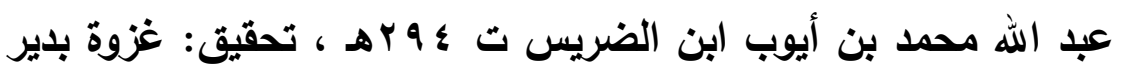

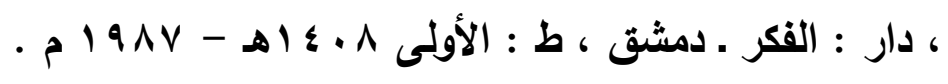

rه. فيض القدير شرح الجامع الصغير للإمام زين الدين محمد ـ المعروف

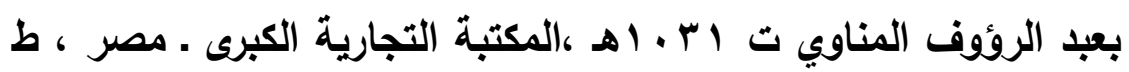

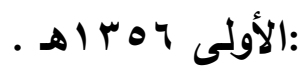

rه. الفردوس بمأثور الخطاب للإمام أبي شجاع الديلمي ، تحقيق السعيد

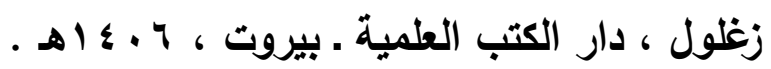


ـه. الكاشف في معرفة من له رواية في الكتب الستة للحافظ أبي عبد الله

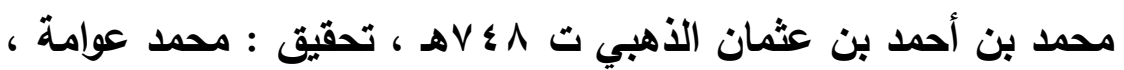

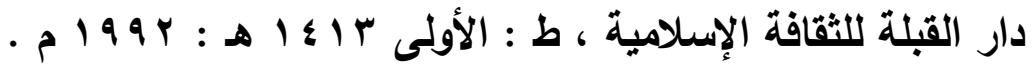
هـ. الكامل في الضعفاء للإمام أبي أحمد بن عدي الجرجاني ت ه ؟به ، تحقيق: عادل أحمد عبد الموجود وغيره ، دار الكتب العلمية - بيروت

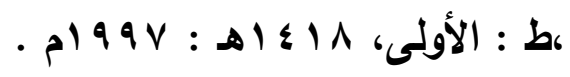

צه. لسان الميزلن للحافظ أبي الفضل أحمد بن علي بن حجر ت بهـه، تحقيق : دائرة المعارف النظامية - الهند، نشرته : مؤسسة الأعلمي

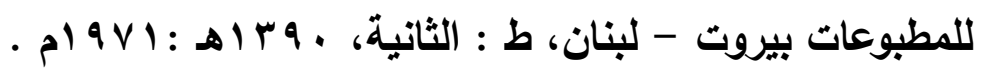

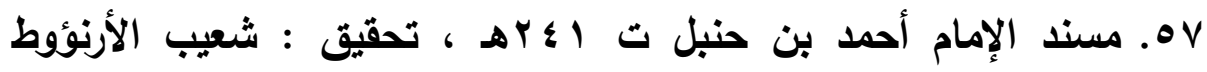

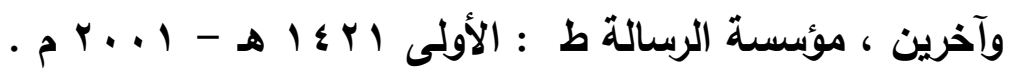

^ه. مسند عبد بن حميد للإمام أبي محمد عبد الحميذ بن حميد بن نصر ت 9 צ هـ ، تحقيق : صبحي البلري السامرائي ، ومحمود محمد خليل

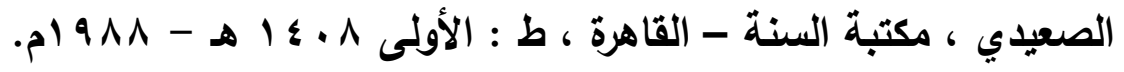
9ه. معرفة أنواع علوم الحديث للحافظ أبي عمرو عثمان بن الصلاح ت بـ 7هـ ، [ المطبوع باسم : مقدمة ابن الصلاح ] تحقيق : نور الدين

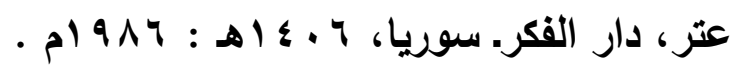

• 7. مفاكهة الخلان في حوادث الزمان للإمام ابن طولون الامشقي ت به هـ ، دار الكتب العلمية ـ بيروت ، ط الاولى 1 إ؛ أهـ . 


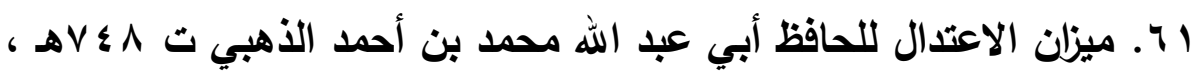

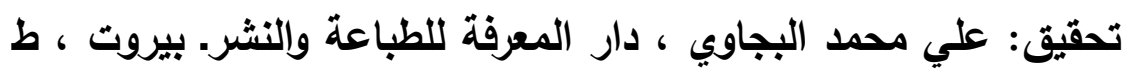

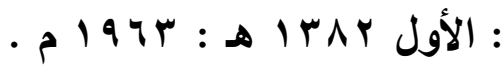

r r. المجالسة وجواهر العلم للإمام أبي بكر أحمد بن مروان الاينوري ت بrrM، تحقيق : أبي عبيدة مشهور بن حسن، الناشر : جمعية

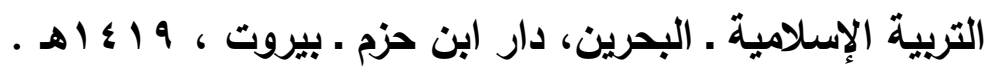

با. المجروحين من المحدثين والضعفاء والمتروكين للإمام محمد بن حبان، البُستي ت كـهـ ، تحقيق : محمود إبراهيم زايل ، دار الوعي . حلب ،

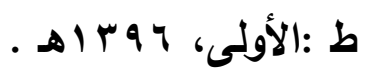
ء 1. المحلي بالآثار شرح المجلي بالاختصار للإمام أبي محمد علي بن أحمد

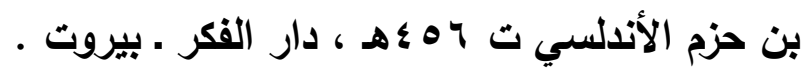
ه . المصنف في الأحاديث والآثار للإمام أبي بكر بن أبي شيبة ت هبr هـ ، تحقيق : كمال يوسف الحوت ، مكتبة الرشد - الرياض ، ط : الأولى لري . $1 \leqslant .9$

צ 7. • ب اهـ ، تحقيق : حمدي بن عبد المجيد السلفي ، مكتبة ابن تيمية القاهرة ، ط : الثانية . 
V V ا المعرفة والتاريخ للإمام يعقوب بن سفيان الفسوي ت S P P ، تحقيق :

أكرم ضياء العمري ، مؤسسة الرسالة . بيروت ، ط : الثانية، 1 . ع 1

$$
\text { - ه }
$$

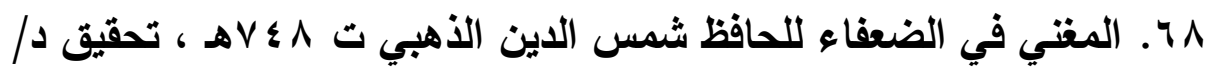
نور الاين عثر

9 9. المنتظم في تاريخ الملوك والأمم للحافظ جمال الدين أبي الفرج عبد الرحمن الجوزي ت Q Vهـ، تحقيق : محمد عبد القادر عطا، دار الكتب

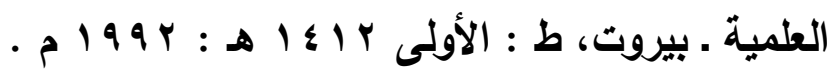

• V. الوافي بالوفيات للإمام صلاح الدين خليل بن أيبك بن عبد الله الصفدي ت: ع צ Yه، تحقيق : أحمد الأرناؤوط ، وتركي مصطقى ، دار إحياء

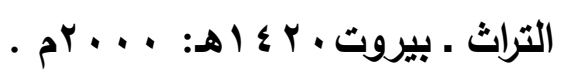

